\title{
IDENTIFICAÇÃO E BIOECOLOGIA DOS CURCULIONÍDEOS-DAS-RAÍZES DOS CITROS \\ DE SÃo PAULO E MINAS geraIS
}

\section{JERSON VANDERLEI CARÚS GUEDES}

Engenheiro Agrônomo

Orientador: Prof. Dr. JOSÉ ROBERTO POSTALI PARRA

\begin{abstract}
Tese apresentada à Escola Superior de Agricultura "Luiz de Queiroz", Universidade de São Paulo, para obtenção do título de Doutor em Ciências, Área de Concentração: Entomologia.
\end{abstract}

PIRACICABA

Estado de São Paulo - Brasil

Janeiro - 2003 


\section{Dados Internacionais de Catalogação na Publicação (CIP) DIVISÃO DE BIBLIOTECA E DOCUMENTAÇÃO - ESALQ/USP}

\section{Guedes, Jerson Vanderlei Carús}

Identificação e bioecologia dos curculionídeos-das-raízes dos citros de São Paulo e

Minas Gerais / Jerson Vanderlei Carús Guedes. - - Piracicaba, 2003.

95 p. : il.

Tese (doutorado) - Escola Superior de Agricultura Luiz de Queiroz, 2003. Bibliografia.

1. Biologia animal 2. Citricultura 3. Coleoptera 4. Comportamento animal 5. Curculionídeo 6. Ecologia animal 7. Flutuação populacional 8. Oviposiçāo I. Título 
Agradeçó e dedico este trabalho aos:

meus pais Eloá e Vando;

minha companheira e amiga Derise;

ao nosso filho Gabriel;

e aos meus irmãos:

Vanderléia, Geza,

Jefferson, Márcio e Acelino. 


\section{AGRADECIMENTOS}

Ao Prof. Dr. José Roberto Postali Parra, do Departamento de Entomologia, Fitopatologia e Zoologia Agrícola da Escola Superior de Agricultura "Luiz de Queiroz" (ESALQ), da Universidade de São Paulo (USP), pela confiança depositada no nosso trabalho, orientação firme, conhecimentos partilhados e exemplos de dedicação à ciência e à Universidade.

A Profa. Dra. Analía Lanteri, pela orientação na parte taxonômica, a Profa. Dra. Marta Loiácono, pela identificação dos Platygastridae, a Enga. Agro. Sonia Suárez, pelo apoio e a todo o pessoal do Museo de La Plata, La Plata - Argentina, pela acolhida.

Ao colega Pesquisador Dr. José Roberto Salvadori da EMBRAPA-Trigo, pela indicação, confiança e pela amizade colorada.

A Universidade Federal de Santa Maria, na pessoa dos Professores e Servidores do Departamento de Defesa Fitossanitária, especialmente aos colegas Ivan Dressler da Costa e Ervandil Corrêa Costa aos Técnicos Angelita Sangoi Martins e Jorge França e ao Prof. Sylvio Bidel Dornelles do Departamento de Biologia.

Aos funcionários da Citrovita, especialmente aos Eng. Agr. Márcio Dinardo e Eduardo A. Lopes; ao José Carlos Brisola ao Éder Polizel e aos técnicos: Alexandre, Francisco, Guilherme, Jair, João Batista, José Carlos, Newton e Ricardo pela colaboração e amizade.

Aos os colegas do PPG em Entomologia, especialmente aos amigos, Amarildo, Américo, Enrique, Charles, Claudia, Denise, Diogo, Dori, Fernando, Gabriela, Jorge, José Francisco, 
Malagueta Trevizan, Marcelo, Márcia, Marcone, Marcos Barros, Marina, Maurício Bento, Miguel, Miguelito, Paulo Paiva, Priscila, Ranise, Ricardo, Rita, Rosângela, Sandra, Saul e Uemerson, pelo convívio fraterno e produtivo.

Aos Funcionários da Escola Superior de Agricultura "Luiz de Queiroz" (ESALQ), especialmente os do Setor de Entomologia, da Biblioteca Central e do Restaurante Universitário, por facilitarem a nossa vida. 


\section{SUMÁRIO}

Página

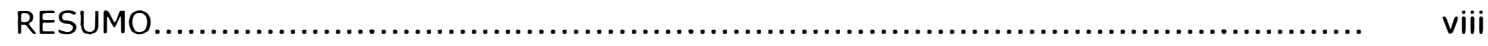

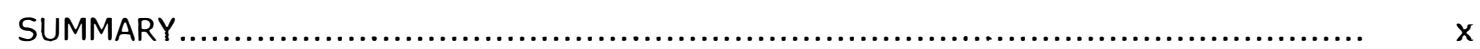

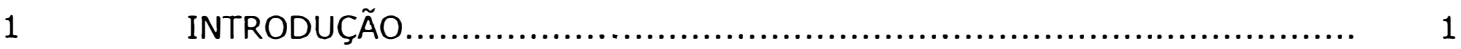

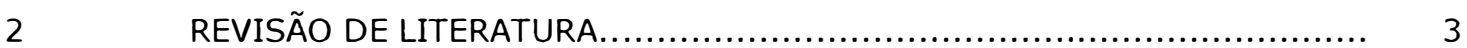

2.1 Espécies e ocorrência dos curculionídeos-das-raízes............................ 3

2.2 Biologia e oviposição dos curculionídeos-das-raízes........................... 4

2.3 Flutuação populacional dos curculionídeos-das-raízes........................... 8

3 IDENTIFICAÇÃO E OCORRÊNCIA DOS CURCULIONÍDEOS-DAS-RAÍZES DOS CITROS EM SÃO PAULO E MINAS GERAIS............................. 11

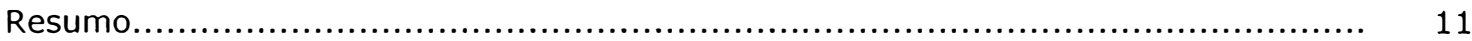

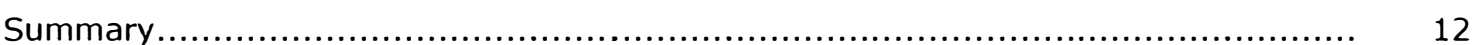

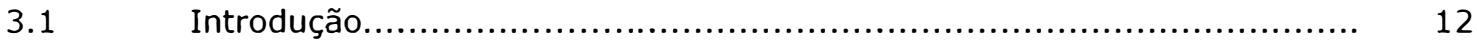

3.2 Material e Métodos............................................................... 13

Resultados e Discussão.................................................... 14

3.3.1 Chave de identificação dos curculionídeos-das-raízes dos citros............... 16

3.3.2 Caracterização das espécies de Curculionidae - Naupactini...................... 19

3.3.3 Ocorrência e distribuição de espécies de curculionídeos-das-raízes dos

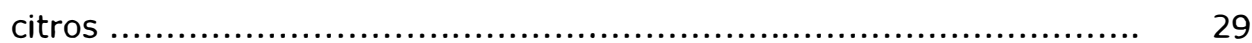

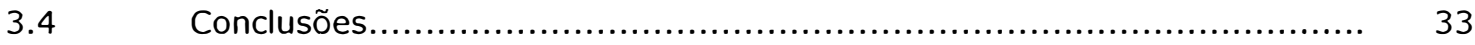

$4 \quad$ BIOLOGIA DOS CURCULIONÍDEOS-DAS-RAÍZES DOS CITROS............... 35

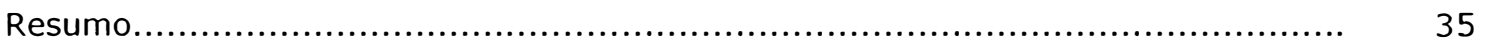

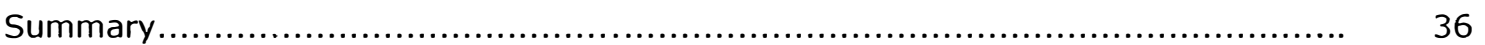




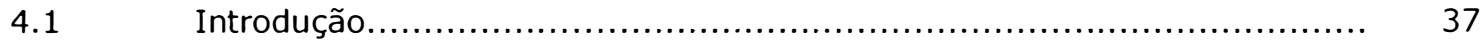

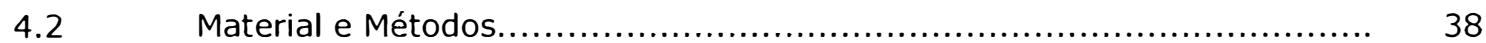

Resultados e Discussão.................................................. 44

4.3.1 Fase de ovo e oviposição em laboratório .................................... 44

4.3.2 Período larva-pupa..................................................... 53

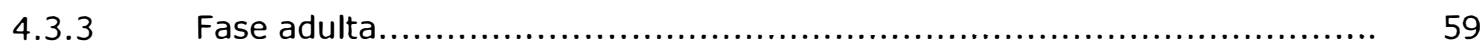

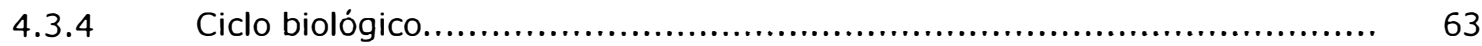

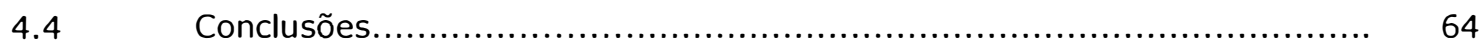

5 FLUTUAÇÃO POPULACIONAL DOS CURCULIONÍDEOS-DAS-RAÍZES DOS

CITROS.............................................................. 66

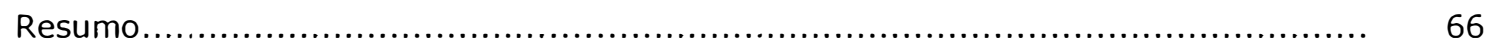

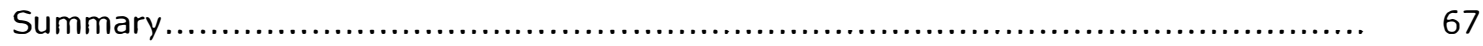

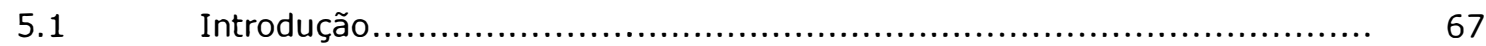

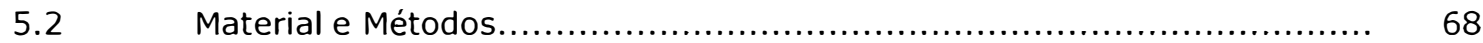

5.2.1 Emergência de adultos e flutuação populacional de adultos na copa......... 69

5.2.2 Flutuação populacional de ovos e distribuição na planta....................... 70

5.2.3 Flutuação populacional de larvas e pupas................................... 71

Resultados e Discussão...................................................... 72

5.3.1 Emergência de adultos e flutuação populacional de adultos na copa......... 73

5.3.2 Flutuação populacional de ovos e distribuição na planta......................... 79

5.3.3 Flutuação populacional de larvas e pupas.................................... 84

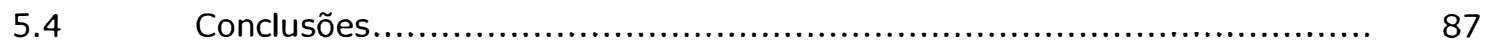

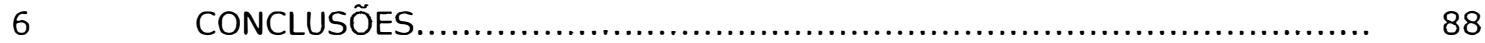

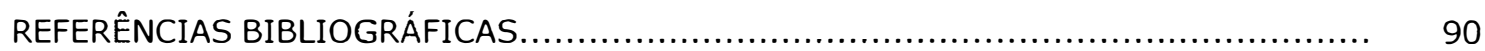




\title{
IDENTIFICAÇÃO E BIOECOLOGIA DOS CURCULIONÍDEOS-DAS-RAÍZES DOS CITROS DE SÃo PAULO E MINAS GERAIS
}

\author{
Autor: JERSON VANDERLEI CARÚS GUEDES \\ Orientador: Prof. Dr. JOSÉ ROBERTO POSTALI PARRA
}

\section{RESUMO}

Os objetivos do trabalho foram descrever as espécies de curculionídeos-das-raízes dos citros de São Paulo e Minas Gerais, fornecer uma chave para sua identificação e definir a freqüência e os locais de ocorrência; estudar características das fases de ovo, larva, pupa e adulta de Naupactus cervinus Boheman, Naupactus versatilis Hustache e Parapantomorus fluctuosus (Boheman) e da sua oviposição e a distribuição das posturas na planta, bem como estudar a flutuação populacional das principais espécies, em Itapetininga, SP. Foram registradas quatorze espécies de Naupactini, em citros. Onze pertencem ao gênero Naupactus Dejean, sendo elas, Naupactus ambiguus Boheman, Naupactus bellus Boheman, N. cervinus, Naupactus cinerosus Boheman; Naupactus curtus Boheman, Naupactus decorus (Fabricius), Naupactus navicularis Boheman, Naupactus rivulosus (Olivier), Naupactus tarsalis Boheman, N. versatilis e Naupactus virens Boheman; uma ao gênero Teratopactus Heller, Teratopactus nodicollis (Boheman); uma ao gênero Parapantomorus Emden, P. fluctuosus e uma ao gênero Symmathetes (gênero revalidado), Symmathetes kollari Schoenherr. Os Naupactini foram encontrados em todas as regiões citrícolas dos estados de São Paulo e Minas Gerais, com maior diversidade de espécies na região centro-sul do estado de São 
Paulo. N. tarsalis, P. fluctuosus e $N$. versatilis ocorreram em um maior número de municípios. A fase de ovo variou de 13,8 a 40,4 dias e os limiares térmicos inferiores de desenvolvimento dessa fase foram de $8,1,8,3$ e $9,9{ }^{\circ} \mathrm{C}$ com constantes térmicas foram de $397,7,385,7$ e 294,1 graus dia (GD), respectivamente, para $N$. cervinus, $N$. versatilis e $P$. fluctuosus. No laboratório, a oviposição dos curculionídeos-das-raízes dos citros foi feita em frutos em fendas estreitas, sob o cálice do fruto, independente da sua cor (estágio de maturação) e também em resíduos vegetais e no solo. O porta-enxerto influenciou a duração do período larva-pupa de $\boldsymbol{N}$. cervinus, que foi de 143 dias em limão cravo e de 200 dias em Citrumelo Swingle. O período larva-pupa de $N$. versatilis foi de 229 dias em limão cravo. O período ovoadulto de $N$. cervinus foi de 162 a 240 dias e de 250 a 269 dias para $N$. versatilis. Ambas as espécies são univoltinas e apresentaram cinco ínstares larvais. A espécie $N$. versatilis é potencialmente mais prejudicial aos citros, pois coloca um número maior de ovos $(214,6$ ovos) do que $N$. cervinus (120,9 ovos), apresenta maior longevidade (30,9 25,2 dias) e consome maior área foliar $\left(31,0 \times 15,0 \mathrm{~cm}^{2}\right)$. A maioria dos adultos emergiu de outubro a abril, com picos no início desse período. As espécies $N$. cervinus e $N$. versatilis foram as mais freqüentes em Itapetininga, SP, embora com picos e épocas diferentes. Em campo, as posturas foram encontradas entre o cálice e a casca dos frutos, em maior número, no interior e nos terços médio e inferior da copa. Ocorreram larvas praticamente o ano inteiro, com picos populacionais no período de junho a janeiro. A população de todas as fases dos curculionídeos foi menor no segundo ano do estudo, provavelmente, em conseqüência da estiagem. Dentre as fases estudadas, os adultos e as larvas, amostrados, respectivamente, com pano-de-batida e em trincheiras no solo, servem à detecção, quantificação e previsão da ocorrência dos curculionídeos-das-raízes dos citros. 


\section{IDENTIFICATION AND BIOECOLOGY OF CITRUS ROOT WEEVILS OF SÃO PAULO AND MINAS GERAIS}

Author: JERSON VANDERLEI CARÚS GUEDES Adviser: Prof. Dr. JOSÉ ROBERTO POSTALI PARRA

\section{SUMMARY}

The goals of this study were to describe the species of citrus root weevils in São Paulo and Minas Gerais, to provide a key to identify and define the frequency and sites of occurrence; to study the characteristics of the egg, larva, pupa and adult stages of Naupactus cervinus Boheman, Naupactus versatilis Hustache and Parapantomorus fluctuosus (Boheman) as well as its oviposition and distribution of eggs laid in plants; it was studied the population dynamics of main species, in Itapetininga, SP. Fourteen Naupactini species were recorded in citrus. Eleven belonging to genus Naupactus Dejean, to name, Naupactus ambiguus Boheman, Naupactus bellus Boheman, N. cervinus, Naupactus cinerosus Boheman; Naupactus curtus Boheman, Naupactus decorus (Fabricius), Naupactus navicularis Boheman, Naupactus rivulosus (Olivier), Naupactus tarsalis Boheman, N. versatilis and Naupactus virens Boheman; one to genus Teratopactus Heller, Teratopactus nodicollis (Boheman); one to genus Parapantomorus Emden, P. fluctuosus and one to genus Symmathetes (revalidated genus), Symmathetes kollari Schoenherr. The Naupactini were found in every citrus region in the states of São Paulo and Minas Gerais, with a larger diversity of species in the centralsouth region of São Paulo state. N. tarsalis, $P$. fluctuosus and $N$. versatilis occurred in a 
higher number of municipalities. The egg stage ranged between 13.8 and 40.4 days and the temperature threshold were $8.1,8.3$ and $9.9^{\circ} \mathrm{C}$ with thermal constant of $397.7,385.7$ and 294.1 degree-days (DD), respectively, for $N$. cervinus, $N$. versatilis and $P$. fluctuosus. In the laboratory, the oviposition of the citrus root weevils took place in fruit slits, under the fruit calyx, regardless of the color (stage of maturation), and also in plant litter and in the soil. The rootstock influenced the duration of the larva-pupa period of $N$. cervinus, which took 143 days in 'Rangpur' lime and 200 days in Swingle citrumelo. The larva-pupa period of $N$. versatilis was 229 days in 'Rangpur' lime. The egg-adult period of $\boldsymbol{N}$. cervinus was 162 to 240 days and 250 to 269 days for $N$. versatilis. Both are univoltine species and had five larval instars. Species $N$. versatilis is potentially more injurious to citrus, for it lays a larger number of eggs (214.6 eggs) than $N$. cervinus (120.9 eggs), has a higher longevity (30.9 $\mathrm{x}$ 25.2 days) and consumes a larger leaf area $\left(31.0 \times 15.0 \mathrm{~cm}^{2}\right)$. Most adults emerged from October through April, with peaks at the beginning of the period. Species $N$. cervinus and $N$. versatilis were more frequently found in Itapetininga, SP, although peaking at different times. In the field, the eggs were laid in a larger number between the the fruit calyx and peel, and also inside the fruit and on the central and lower third parts of the crown. Larvae occurred nearly throughout the year, with population peaks in the period of June-January. The population of all curculionids was lower in the second year of study, probably because of drought. In the stages studied, the adults and larvae sampled with beating cloth and ditches, respectively, can be used for detecting, quantifying and predicting the occurrence of citrus root weevils. 


\section{INTRODUÇÃO}

O Brasil é o maior produtor de frutos cítricos e o maior exportador mundial de suco concentrado de laranja. Esse desempenho posiciona a citricultura como uma das atividades agrícolas da maior importância econômica para a região Sudeste do Brasil, que apresenta um excelente nível de produtividade e competitividade. O estado de São Paulo é responsável por aproximadamente $80 \%$ da produção dessa região, com cerca de 18 milhões de toneladas de frutas na safra 2001 (FNP Consultoria e Comércio, 2002).

Os citros, no entanto, apresentam diversos problemas fitossanitários, que podem limitar sua produção e incrementar os custos de produção, destacando-se, entre eles, os ácaros e os insetos-praga. Dentre os insetos, os besouros da família Curculionidae são relatados nos citros há décadas, embora apenas recentemente tenham sido registrados aumentos dos seus níveis populacionais. Assim, os curculionídeos-das-raízes dos citros podem, atualmente, serem considerados pragas primárias da cultura, em algumas regiões produtoras dos estados de São Paulo e de Minas Gerais (Guedes et al., 2002), e há dificuldades de controlá-los devido à falta de conhecimento da sua bioecologia.

Os danos diretos são causados pelos adultos dos curculionídeos-das-raízes, às folhas dos citros, entretanto, os danos diretos mais importantes são ocasionados pelas larvas, ao sistema radicular das plantas nas quais produzem ferimentos que facilitam a entrada de patógenos, tais como Phytophthora spp. (Gravena et al., 1992) que causam várias doenças importantes do colo e do sistema radicular das plantas cítricas (Siveiro et al., 2002).

As espécies de curculionideos-das-raízes dos citros apresentam ciclos de vida semelhantes (McCoy, 1994). Assim, os adultos recém emergidos, migram para a copa das plantas, onde se alimentam das folhas. As fêmeas ovipositam sob o cálice dos frutos e, 
algumas espécies no solo. As larvas eclodem e se desenvolvem no solo onde consomem radicelas, raízes finas e a casca das raízes mais grossas, até passarem à fase de pupa, ainda no solo e transformarem-se em adultos, completando o ciclo (Guedes, 2001).

Como comentado, faltam estudos sobre as espécies, biologia e ecologia dos curculionídeos-das-raízes que ocorrem em citros no Brasil, aspectos essenciais ao manejo racional e econômico desse grupo de insetos-praga. Na falta dessas informações, o controle desses insetos é feito de forma empírica e aleatória, contribuindo para custos ambientais e econômicos elevados, com resultados pouco satisfatórios e contribuindo para o agravamento do problema, em virtude dos desequilíbrios biológicos causados.

Desta forma, os objetivos desse trabalho foram: 1) descrever as espécies de curculionídeos-das-raízes dos citros, elaborar uma chave de identificação das mesmas e estudar a sua ocorrência e distribuição na área citrícola dos estados de São Paulo e Minas Gerais; 2) estudar algumas características das fases de ovo, larva, pupa e adulta das principais espécies de curculionídeos-das-raízes dos citros e 3) estudar a flutuação populacional dos curculionídeos-das-raízes dos citros e a oviposição das principais espécies, em campo. 


\section{REVISÃO DE LITERATURA}

\subsection{Espécies e ocorrência dos curculionídeos-das-raízes}

Em citros, na Flórida (EUA), ocorrem oito espécies de curculionídeos-das-raízes, com destaque às espécies Diaprepes abbreviatus L. e Naupactus cervinus (Boheman) (Woodruf, 1985). Apesar de ser conhecido e estudado há muitas décadas, esse grupo de pragas onera os custos anuais de controle, em mais de 70 milhões de dólares. Há, no entanto, uma diferença entre a citricultura norte-americana e a brasileira, uma vez que nos EUA as espécies mais importantes são $D$. abbreviatus e $P$. cervinus, exóticas, sendo a primeira mais importante economicamente (McCoy et al., 1985). Na Austrália, N. cervinus é a espécie mais importante em laranjeiras (Edwards et al., 1993).

Na América do Sul, os estudos sobre a ocorrência dos curculionídeos-das-raízes foram realizados na Argentina por Lanteri et al. (1994) que verificaram a ocorrência de 22 espécies de Naupactini em alfafa, pertencentes aos gêneros Cyrtomon, Priocyphus, Naupactus, Pantomorus, Aramigus, Asynonychus, Atrichonotus, Eurymetopus e Trichonaupactus. No Uruguai Alzugaray et al. (1998) estudaram os curculionídeos-das-raízes em pastagens (alfafa e cornichão) onde verificaram a ocorrência de dez espécies, dos gêneros Naupactus, Pantomorus, Atrichonotus, Eurymetopus e Aramigus.

Woodruff (1985) registrou a ocorrência de onze gêneros de Curculionidae, em citros, nos EUA (Flórida) e nas Antilhas, (Arpitus, Cleistolophus, Compsus, Diaprepes, Epicaerus, Exophthalmus, Lachnopus, Litostylus, Pachnaeus, Pantomorus e Tanymecus), destacando, que os laranjais recentemente introduzidos na região, servem de hospedeiro 
para essas espécies que, originalmente atacavam plantas de outras famílias, além das rutáceas.

No Brasil, em levantamento efetuado na região noroeste do estado de São Paulo, através de observação visual, com pano-de-batida e com armadilhas de emergência teladas, em pomar das variedades Lima e Pêra, Munuera (1992), verificou a ocorrência de mais de dez espécies, entre elas Parapantomorus fluctuosus (Boheman), Naupactus rivulosus (Olivier), Naupactus tarsalis Boheman, Naupactus transversus Boheman, Naupactus versatilis Hustache, Naupactus roseiventris Boheman, Naupactus cinerosus Boheman, Naupactus cervinus Boheman, Lytostylus sp. e Comptus argyreus (L.). Pinto et al. (1996) estudaram a ocorrência de curculionídeos-das-raízes em pomares de laranjeiras, onde foram observadas as espécies: Teratopactus nodicollis (Boheman), P. fluctuosus, Cydianerus latruncularis (Perty), N. rivulosus e N. tarsalis em Comendador Gomes, MG; as espécies: P. fluctuosus, N. tarsalis, Naupactus fatuus Boheman, Naupactus optatus (Herbst) e N. transversus em Ribeirão Bonito, SP e as espécies $P$. fluctuosus, $N$. tarsalis e Naupactus proximus Voss em Bebedouro, SP.

Woodruff (1985) e Mauleon \& Mademba-Sy (1988) ressaltam que a correta identificação das espécies de curculionídeos-das-raízes dos citros é fundamental para o estudo da biologia, ecologia e comportamento, que são as bases do manejo de pragas. Entretanto, tal identificação é dificultada pela grande variabilidade de coloração, morfologia e biologia da maioria das espécies listadas.

\subsection{Biologia e oviposição dos curculionídeos-das-raízes}

A duração da fase de ovo de $N$. cervinus, foi estudada em laboratório por Lakin \& Morse (1989), em diferentes temperaturas e umidades relativas. O limite térmico inferior variou de 10,21 a $11,70{ }^{\circ} \mathrm{C}$, sendo necessários de 251 a 351 GD para completar a fase 
embrionária. Segundo Edwards et al. (1993) o ciclo biológico de $N$. cervinus dura em torno de seis meses.

Tarrant \& McCoy (1989) avaliaram o efeito combinado da temperatura e da umidade relativa sobre a eclosão de larvas e as temperaturas letais para larvas de Artipus floridanus Horn, Pachnaeus litus (Germar), Pachnaeus opalus (Olivier) e N. cervinus, pragas dos citros na Califórnia (EUA). Os maiores percentuais de sobrevivência do embrião foram obtidos com umidades entre 80 e $100 \%$ e temperaturas entre 20 e $30^{\circ} \mathrm{C}$; larvas recém eclodidas sobreviveram entre -5 a $50^{\circ} \mathrm{C}$, embora $N$. cervinus sobreviva somente até $40^{\circ} \mathrm{C}$; na temperatura de $35^{\circ} \mathrm{C}$ e umidade relativa de $40 \%$ a eclosão de larvas dessa espécie caiu para valores em torno de $10 \%$.

Lanteri et al. (2002) caracterizaram oito tipos de oviposição para os curculionídeos que ocorrem na Argentina. Os Naupactini foram classificados em duas categorias, a primeira para aqueles que ovipositam em massas aderidas em fendas ou dobras de folhas e a segunda para os que ovipositam no solo, sendo que ambas as categorias não utilizam o rostro para elaborar o local de postura. As fêmeas dos Curculionidae de rostro curto (Naupactini), colocam seus ovos na face abaxial e adaxial das folhas, protegidos nas dobras dessas folhas ou em fendas presentes na casca da planta (Marvaldi, 1999; Lanteri et al., 2002). Lakin \& Morse (1989) estudaram o comportamento de oviposição de $N$. cervinus em dois substratos, em laboratório, observando que as fêmeas realizam postura tanto no fruto quanto em papel de filtro, entretanto, a eclosão de larvas foi bastante reduzida nesse último substrato, que sob umidade baixa é ainda mais afetada, atrasando o desenvolvimento embrionário. A postura de $D$. abbreviatus foi detalhadamente estudada em laboratório utilizando-se plástico transparente, na temperatura de $27 \pm 2{ }^{\circ} \mathrm{C}, \quad 30 \%$ UR e fotofase de 11 horas. A fêmea distende o ovipositor e deposita uma linha de ovos, depositando outras linhas, paralelamente às primeiras, logo em seguida. Em seqüência, deposita sobre a postura uma camada de substância adesiva. Para efetuar uma postura de aproximadamente 100 ovos, uma fêmea leva em torno de cinco minutos (Adair et al. 1999). A oviposição de D. abbreviatus foi 
estudada por Schroeder (1981) em gaiolas de 1,0 $\mathrm{m}^{2}$, em campo, onde observou que mais de $80 \%$ da postura é realizada à noite nas folhas dos citros.

Para a mesma espécie, Viladerbó \& Biosseau (1988) obtiveram um período de incubação de 6-7 dias, a fase larval de 90-95 dias, o período de pré-pupa de 60-70 dias (os insetos eram transferidos para um meio não nutritivo, composto principalmente de terra), a fase de pupa de 15-20 dias, totalizando 169 a 207 dias para o período ovo-adulto, ou seja, uma redução da duração do ciclo, em relação à Beavers (1982), embora utilizando dieta e técnica semelhantes. Esses resultados foram parcialmente confirmados por Lapointe \& Shapiro (1999), que também a $25^{\circ} \mathrm{C}$ e UR de $30-70 \%$, obtiveram a duração de 180 dias para a fase larval de $D$. abbreviatus, criado em dieta artificial, com a transferência das larvas para o solo, para pupação.

No Chile, Ripa (1992) verificou que o ciclo biológico de Naupactus xanthographus (Germar), praga da parte aérea e raízes da videira, se inicia com a oviposição na planta, sob a casca do tronco. O período embrionário, em campo, dura de 32 a 42 dias. As larvas recém eclodidas vão para o solo em fevereiro e essa fase dura até outubro (210 dias, aproximadamente). A fase de pupa dura em torno de 30 dias e os adultos recém emergidos permanecem no solo de 25 a 30 dias para endurecimento do exoesqueleto, para então saírem à superfície do solo. O ciclo completo dessa espécie leva de dez a 12 meses, em média. Em alguns casos, os adultos permanecem no solo por quatro a cinco meses, aumentando o ciclo para 16 meses. Segundo Gonzalez (1982), em laboratório, os adultos de N. xantographus vivem de três a oito meses e em campo de um a quatro meses.

A biologia de Naupactus leucoloma Boheman foi estudada em campo (alfafa) e em laboratório por De Jager et al. (1989) na África do Sul. A espécie apresentou um ciclo de vida de 12 a 15 meses e fase larval de nove a 12 meses. A fase pupal variou de 14 a 30 dias, dependendo da temperatura. Ottens \& Todd (1979) estudaram a longevidade, fecundidade, e os períodos de pré-oviposição e de oviposição de $N$. leucoloma em dez diferentes hospedeiros. Os parâmetros biológicos variaram de acordo com o alimento utilizado. A longevidade variou de 58 a 170 dias (sorgo e abóbora); a fecundidade de 24 a 1031 
ovos/fêmea (milho e amendoim); pré-oviposição de 20 a 42 dias (invasoras e milho) e a oviposição de 12 a 134 dias (milho e abóbora) demonstrando que o desempenho da variável biológica de uma espécie apresenta relação com o alimento utilizado pelas fêmeas na fase adulta.

N. leucoloma é amplamente distribuido na Argentina, ocorrendo também no Brasil e no Uruguai. Foi introduzido no Chile, Peru, EUA, África do Sul, Austrália e Nova Zelândia e apresenta mais de 240 hospedeiros (Lanteri et al., 1994). Na Argentina os machos são raros, fortalecendo a hipótese de reprodução partenogenética para essa espécie. A partenogênese é relatada para a tribo Naupactini, em cujo grupo se encontram Naupactus e Pantomorus, gêneros verificados em áreas subtropicais e temperadas da América do Sul, inclusive do Brasil. A reprodução partenogenética permite às espécies uma alternativa de desenvolvimento, tornando o controle dos insetos-praga mais complexo (Lanteri \& Normark, 1995).

A dificuldade de acesso ao solo e às raizes, compromete a avaliação dos danos causados pelos curculionídeos rizófagos (Murray \& Clements, 1992), de tornar o estudo da fase larval desse grupo de insetos (Naupactini) mais trabalhoso (Gonzalez, 1983), e, portanto, menos conhecida. Assim, são os poucos estudos sobre o número de ínstares, sendo os existentes. Segundo o mesmo autor $N$. xantographus apresenta seis instares, sendo cinco com crescimento e mobilidade e um sexto instar pré-pupal inativo; entretanto, para De Gregori citado por Loiácono \& Marvaldi (1994), essa espécie teria sete ínstares larvais. De Jager et al. (1989), observaram a ocorrência de sete instares, em larvas de $N$. leucoloma coletadas em campo. A mesma espécie apresentou 11 instares, para larvas alimentadas com cenoura, em laboratório (Gough \& Brown, 1991) e com trevo branco e gramíneas (Hardwick \& Prestidge, 1996). Segundo McCoy et al. (1985) A. floridanus, praga dos citros na Califórnia (EUA), apresenta seis ínstares larvais, quando criado, em laboratório, em dieta artificial.

O dano causado por A. floridanus às folhas dos citros, foi estudado por Sylvertsen \& McCoy (1985). Os danos à folhagem são proporcionais às populações e ao tempo de exposição aos insetos; os danos iniciam-se nas bordas das folhas sem chegar à nervura 
central e as fêmeas consomem maior área foliar do que os machos. Nas folhas mais danificadas ocorreu maior perda de água do que redução de fotossíntese, com queda na eficiência do uso da água, importante em situações de seca. Para a mesma espécie, McCoy et al. (1985) observaram maior consumo das folhas de citros no período noturno.

\subsection{Flutuação populacional dos curculionídeos-das-raizes}

No Chile, em diferentes regiões cultivadas com videira, Ripa (1992) verificou que a população de $N$. xanthographus flutua de forma semelhante entre os locais e os anos observados. Os adultos emergem de setembro a maio e os maiores picos populacionais são verificados de dezembro a fevereiro. Os picos populacionais apresentam relação direta com temperaturas do solo superiores a $15^{\circ} \mathrm{C}$. A oviposição dos adultos da primeira emergência foi verificada a partir de meados de novembro, indo até dezembro. Entretanto, a postura das fêmeas das emergências posteriores, foi de janeiro até maio, reduzindo-se a partir de abril. As larvas são encontradas desde dezembro, sendo observadas em elevadas populações até setembro. As pupas são encontradas, preferencialmente, de novembro a abril, sendo mais abundantes no início do período. Nas amostras de solo, também são encontrados adultos apresentando o exoesqueleto ainda não completamente esclerozado, em razão de permanecerem no solo por 25-30 dias, antes de saírem à superfície.

Na África do Sul, De Jager et al. (1989) observaram que larvas de diferentes ínstares de $\mathrm{N}$. leucoloma ocorrem durante o ano inteiro, em alfafa. As larvas, provenientes de posturas dos adultos emergidos de fevereiro a abril, levaram 12 meses para chegar à fase de pupa, enquanto que as oriundas dos adultos emergidos no fim de janeiro levaram somente nove meses para pupar. Os autores afirmam ainda que a temperatura é o fator determinante da duração da fase de pupa e adulta; assim, foram verificadas pupas em outubro e também de fevereiro a março. A flutuação populacional de larvas dessa espécie foi estudada por Hardwick \& Prestidge (1994), em pastagens de trevo e gramíneas, na Nova Zelândia. Os 
adultos ocorreram de novembro a março, com um pico em janeiro e fevereiro; foram verificadas larvas dos últimos ínstares ( 8 ao $11^{\text {을 }}$ durante todo o ano, entretanto, somente foi observado um pico para pupas e outro para adultos, indicando alta mortalidade nos últimos ínstares e/ou da fase de pupa. No Alabama (EUA), Zehnder (1997) estudou a flutuação populacional das diferentes fases de Naupactus peregrinus (Buchanan) e de N. leucoloma, espécies que coexistem em batata doce, sendo que $N$. peregrinus é predominante sobre a outra espécie de Naupactini. Os adultos das duas espécies foram observados de agosto a outubro, com picos em agosto ou setembro e as larvas de junho a janeiro, com pico em novembro.

As flutuações populacionais dos adultos de $N$. cinerosus, de Atrichonotus taeniatulus (Berg) e de Naupactus cinereidorsum Hustache foram estudadas em dois anos seguidos, na Argentina, por Brewer \& Varas (1974) em alfafa. As populações de $N$. cinereidorsum e de $A$. taeniatulus se sucederam no tempo e foram mais numerosas do que a de $N$. cinerosus; para as duas espécies mais numerosas, ocorreu um grande declínio populacional no segundo ano de amostragem. Os adultos de $N$. cinereidorsum ocorreram de novembro a julho, com picos em janeiro e fevereiro; a população de $A$. taeniatulus ocorreu de fevereiro a maio, com picos em fevereiro e março e os adultos de $N$. cinerosus ocorreram de dezembro a abril, com pico em fevereiro. De forma análoga, Lanteri e Aragón (1994) afirmam que em alfafa, na Argentina, a emergência dos adultos dos Naupactini ocorre de novembro a abril, enfatizando ainda, que os picos populacionais das espécies se sucedem em diferentes momentos do período, permitindo às espécies similares, uma melhor exploração dos recursos disponíveis.

Em citros, a população de adultos do curculionídeos-das-raízes $D$. abbreviatus foi avaliada por Beavers \& Selhime (1975), na variedade Hamlin, na Flórida, EUA. A emergência dos adultos geralmente tende a aumentar, a partir de abril até junho, com as maiores populações sendo verificadas de agosto a dezembro, apesar de ocorrerem praticamente durante o ano todo. Em determinados anos, não foram encontrados adultos em fevereiro e 
março. Os autores observaram ainda que os picos de emergência ocorrem com altas temperaturas, precedidas de elevadas precipitações pluviométricas.

A oviposição de $N$. cervinus foi estudada em campo, por Coats \& McCoy (1990), no EUA, em citros acondicionados em gaiolas teladas, isoladas do solo, devido à espécie efetuar posturas nesse substrato, em um pré-teste. Concentraram-se nos frutos $82,6 \%$ dos ovos, sendo que mais de $99,0 \%$ desses ovos são colocados sob o cálice; $16,2 \%$ são postos nas folhas e raramente são encontradas posturas nos ramos. A oviposição cresceu em todos os substratos a medida que aumentou o número de insetos, variando de 60,0 a $90,0 \%$ dos ovos nos frutos, para 10 insetos/planta. 


\section{IDENTIFICAÇÃO E OCORRÊNCIA DOS CURCULIONÍDEOS-DAS-RAÍZES DOS CITROS EM SÃO PAULO E MINAS GERAIS}

Resumo

O objetivo do trabalho foi descrever as espécies de curculionídeos-das-raízes que ocorrem nos citros e fornecer uma chave para sua identificação; com tais informações definiu-se sua ocorrência e distribuição na área citrícola dos estados de São Paulo e Minas Gerais. São registradas quatorze espécies de Entiminae, Naupactini, que ocorrem em Citrus nos estados de São Paulo e Minas Gerais, Brasil. Dessas espécies, onze pertencem ao gênero Naupactus Dejean, sendo elas, Naupactus ambiguus Boheman, Naupactus bellus Boheman, Naupactus cervinus Boheman, Naupactus cinerosus Boheman; Naupactus curtus Boheman, Naupactus decorus (Fabricius), Naupactus navicularis Boheman, Naupactus rivulosus (Olivier), Naupactus tarsalis Boheman, Naupactus versatilis Hustache e Naupactus virens Boheman; uma ao gênero Teratopactus Heller, Teratopactus nodicollis (Boheman); uma ao gênero Parapantomorus Emden, Parapantomorus fluctuosus (Boheman) e uma ao gênero Symmathetes (gênero revalidado), Symmathetes kollari Schoenherr. Os curculionídeos-dasraízes foram encontrados em todas as regiões citrícolas dos estados de São Paulo e Minas Gerais, sendo a região centro-sul do estado de São Paulo a que apresentou maior número de espécies. $\boldsymbol{N}$. tarsalis, P. fluctuosus e $\boldsymbol{N}$. versatilis ocorreram em maior número de municípios indicando uma possível adaptação dessas espécies aos citros. 


\section{Summary}

This research was carried out to describe the citrus root weevils that occur in citrus groves, to provide a key to species identification and also to study the occurrence and distribution in São Paulo and Minas Gerais states. Fourteen species of broad nosed weevils belonging to Entiminae, Naupactini, are recorded as harmful to roots of citrus in São Paulo and Minas Gerais states, Brazil. Most species belong to Naupactus Dejean; Naupactus ambiguus Boheman, Naupactus bellus Boheman, Naupactus cervinus Boheman, Naupactus cinerosus Boheman; Naupactus curtus Boheman, Naupactus decorus (Fabricius), Naupactus navicularis Boheman, Naupactus rivulosus (Olivier), Naupactus tarsalis Boheman, Naupactus versatilis Hustache and Naupactus virens Boheman; one to Teratopactus Heller, Teratopactus nodicollis (Boheman); one to Parapantomorus Emden, Parapantomorus fluctuosus (Boheman) and one to Symmathetes (a genus herein reinstated), Symmathetes kollari Schoenherr. The citrus root weevils are distributed in very citrus grove in São Paulo and Minas Gerais States, mainly in the São Paulo center-south region. $N$. tarsalis, P. fluctuosus and $N$. versatilis were present in a higher number of cities, showing a possible adaptation of the species to citrus.

\subsection{Introdução}

Os citros apresentam grande importância econômica para a região Sudeste, porém sua produção apresenta diversos problemas fitossanitários. Dentre estes, os ácaros e os insetos-praga, podem limitar a produção e elevar os custos de controle, reduzindo sua competitividade. Segundo Gravena (1997), entre essas pragas, destacam-se as cigarrinhasda-CVC; o bicho-furão, Ecdytolopha aurantiana (Lima); o minador-das-folhas Phyllocnistis citrella Stainton; o ácaro-da-leprose Brevipalpus phoenicis (Geijskes) e o ácaro-da-ferrugem Phillocoptruta oleivosa (Ashmead), além dos curculionídeos-das-raízes dos citros.

Os curculionídeos-das-raízes, embora relatados há muitos anos como pragas secundárias da cultura dos citros, nos últimos anos têm aumentado sua importância nas 
diferentes regiões produtoras dos estados de São Paulo e Minas Gerais, tanto pelas dificuldades de controle (devido ao desconhecimento da sua bioecologia), quanto pela sua expansão para novas áreas cultivadas (Guedes et al., 2002), proporcionando assim, a elevação dos níveis populacionais da praga e do custo do controle.

A importância desse grupo de insetos está relacionada principalmente às larvas, que dependendo dos danos produzidos nas raízes, podem causar o declínio precoce das plantas e facilitar a disseminação de patógenos, tais como Phytophthora spp. agente causal da gomose dos citros. Em menor escala, os danos podem ser causados também pelos adultos que consomem folhas e apresentam importância para plantas jovens.

Os estudos sobre curculionídeos-das-raízes têm relatado a ocorrência de várias espécies conjuntamente (complexos) em culturas como citros, alfafa e pastagens. Esses agrupamentos freqüentemente ultrapassam dez espécies, embora também ocorram casos de uma ou poucas espécies por cultura, como na videira, macieira, feijoeiro, soja e essências florestais.

Este trabalho teve por objetivo descrever espécies de curculionídeos-das-raizes encontradas nos citros, elaborar uma chave de identificação das mesmas e estudar a sua ocorrência e distribuição na área citrícola dos estados de São Paulo e Minas Gerais.

\subsection{Material e Métodos}

O levantamento das espécies de curculionídeos-das-raízes foi realizado na área citrícola do estado de São Paulo e de Minas Gerais. Os insetos adultos foram coletados em fazendas de 33 municípios das regiões citrícolas, onde a ocorrência foi diagnosticada através de um questionário (Guedes et al., 2002) e nas áreas com histórico de danos (Munuera, 1992; Gravena et al., 1992; Pinto et al., 1996). A ocorrência foi avaliada nos seguintes municípios do estado de São Paulo: Américo Brasiliense, Analândia, Araras, Barretos, Bauru, Bebedouro, Boa Esperança do Sul, Borborema, Botucatu, Casa Branca, Cafelândia, Cosmorama, Descalvado, Divinópolis, Guaraci, Guarantã, Indiaporã, Itapetininga, Itápolis, 
José Bonifácio, Limeira, Matão, Monte Azul Paulista, Olímpia, Pederneiras, Piracicaba, Pongaí, Ribeirão Bonito, Santa Rita do Passa Quatro, Ubarana e Votuporanga; no estado de Minas Gerais em Frutal e Uberaba.

Durante a época de maior ocorrência dos adultos (outubro a março dos anos de 2001 ou 2002) foi feita uma amostragem por local (fazenda). A amostragem consistiu da coleta dos insetos em 40 plantas, através de um pano-de-batida branco medindo 4,0 × 4,0 $\mathrm{m}$, colocado sob a copa. Após as plantas serem sacudidas sobre o pano, os insetos eram coletados e levados ao Laboratório de Biologia de Insetos do Departamento de Entomologia, Fitopatologia e Zoologia Agrícola da ESALQ/USP.

Para a identificação dos insetos, sua descrição baseou-se nos caracteres morfológicos dorsais e em outras estruturas externas como: tegumento e revestimento, cabeça, pronoto, élitros e asas, pernas e ovipositor. Para o estudo da parte terminal das genitálias e das espermatecas das fêmeas, os exemplares foram colocados em câmara úmida por 12 horas; o abdome foi destacado e imerso em solução de $\mathrm{KOH}$ saturada, por 24 horas; em seguida, as partes foram observadas em microscópio esteroscópico. Foram realizadas ilustrações com auxílio de câmara clara, da cabeça, pronoto, pernas e espermatecas; a parte terminal das genitálias foi fotografada, seguindo metodologia adaptada de Lanteri et al. (1994). Para confirmação específica, os exemplares foram enviados à Dra. Analía A. Lanteri do Museo de La Plata, em La Plata, Argentina.

Foram elaborados uma chave de identificação e um mapa de distribuição das espécies de curculionídeos-das-raízes que ocorreram em, no mínimo, dois locais (municípios) da área citrícola estudada dos estados de São Paulo e Minas Gerais.

\subsection{Resultados e Discussão}

Foi registrada a ocorrência de 14 espécies pertencentes a quatro gêneros de curculionídeos-das-raízes da subfamília Entininae, tribo Naupactini, em citros, nos estados de São Paulo e Minas Gerais, Brasil. Das 14 espécies, onze delas pertencem ao gênero 
Naupactus Dejean, ou seja, Naupactus ambiguus Boheman, Naupactus bellus Boheman, Naupactus cervinus Boheman, Naupactus cinerosus Boheman; Naupactus curtus Boheman, Naupactus decorus (Fabricius), Naupactus navicularis Boheman, Naupactus rivulosus (Olivier), Naupactus tarsalis Boheman, Naupactus versatilis Hustache e Naupactus virens Boheman; uma ao gênero Teratopactus Heller, Teratopactus nodicollis (Boheman); uma ao gênero Parapantomorus Emden, Parapantomorus fluctuosus (Boheman) e uma ao gênero Symmathetes (gênero revalidado), Symmathetes kollari Schoenherr. Na presente pesquisa, a exemplo dos trabalhos de Lanteri et al. (1994) em alfafa na Argentina e de Alzugaray et al. (1998) em pastagens no Uruguai, além daqueles realizados em citros por Woodruff (1985) nas Antilhas e na Flórida (EUA) e por Munuera (1992) e Pinto et al. (1996) no Brasil, ocorrem populações, geralmente com mais de dez espécies na mesma cultura. Algumas das espécies como $N$. cervinus, $N$. ambiguus e $P$. fluctuosus foram encontradas nos citros e também em outras culturas fora do Brasil, demonstrando sua ampla distribuição e adaptação a outros cultivos, além das rutáceas. Sete das 14 espécies verificadas nesse trabalho tinham sido relatadas por Munuera (1992), em citros no estado de São Paulo, porém sem especificar os locais de coleta enquanto que quatro foram encontradas por Pinto et al. (1996) em levantamento em Bebedouro e Ribeirão Bonito, SP e em Comendador Gomes, MG.

As espécies de curculionídeos-das-raízes dos citros caracterizam-se por apresentar rostro curto percorrido por um sulco mediano longitudinal e mandíbulas com um apêndice distal que se solta após a emergência (Ripa, 1986; Lanteri et al., 1994); medem de 5 a $20 \mathrm{~mm}$ de comprimento da extremidade do rostro ao ápice do élitro. Os maiores espécimens encontrados foram as fêmeas de $N$. rivulosus, $N$. tarsalis e $T$. nodicollis e os menores foram os machos de S. kollari. O tegumento dos adultos em geral é castanho ou preto e apresenta-se total ou parcialmente revestido por escamas de tamanho e coloração variados, opacas ou iridiscentes.

Segundo Lanteri et al. (1994) o gênero Naupactus inclui espécies medianas a grandes (maiores que $10 \mathrm{~mm}$ ) com antenas longas, "ombros" salientes, asas metatorácicas desenvolvidas e populações bissexuais. Pantomorus, em contrapartida, apresenta formas 
pequenas (menores que $10 \mathrm{~mm}$ ), antenas medianas a curtas, "ombros" ausentes, asas metatorácicas não desenvolvidas e população formada somente por fêmeas partenogenéticas. Entretanto, recentemente, considera-se que o gênero Naupactus Dejean em sentido amplo, pode incluir também espécies que estavam no gênero Pantomorus Schoenherr (Lanteri, 2002, inf. pessoal). Esse entendimento, somado aos aspectos morfológicos e fisiológicos que dificultam a separação dos dois gêneros, orientou a colocação das espécies de "Pantomorus típicos" também no gênero Naupactus, pois algumas espécies apresentam características intermediárias, tornando a separação difícil.

\subsubsection{Chave de identificação dos curculionídeos-das-raízes dos citros}

1 - Pronoto com um par de tubérculos medianos nas laterais. "Ombros" com um par de tubérculos dentiformes laterais. Uma fileira de dentículos na face interna dos três pares de tíbias. Ovipositor sem estilos terminais com hemiesternitos fortemente esclerosados e em forma de unha (Figura 3i)................ Teratopactus nodicollis (Boheman) (Figura 1a)

1' - Pronoto e "ombros" sem tubérculos dentiformes laterais. Tíbias anteriores com ou sem uma fileira de dentículos na face interna; tíbias médias e posteriores sem dentículos. Ovipositor com estilos terminais, hemiesternitos levemente esclerosados (Figura $3 \mathrm{~h}$ ).... 2

2 - Espécies grandes com 15 a 23 mm de comprimento. Base dos élitros sinuosa. "Ombros" muito salientes. Asas metatorácicas desenvolvidas. 3

2' - Espécies medianas e pequenas, com 6 a $13 \mathrm{~mm}$ de comprimento. Base dos élitros reta. "Ombros" salientes ou ausentes. Asas metatorácicas desenvolvidas, reduzidas ou ausentes

3 - Olhos muito convexos (Figura 3a). Pronoto com borda anterior curvada e com um sulco mediano longitudinal. Pronoto + élitros com listras compostas por escamas de coloração vermelha, amarela, laranja ou esverdeadas..... Naupactus rivulosus (Olivier) (Figura 1b) 
3' - Olhos pouco convexos (Figura 3b). Pronoto com borda anterior reta, sulco mediano longitudinal ausente. Pronoto + élitros com um par de listras com escamas, de coloração branca ou verde iridiscente, interrompidas ou não, com ou sem pulverulência amarela nas laterais. Naupactus tarsalis Boheman (Figura 1c)

4 - Pronoto globoso muito convexo dorsalmente (Figura 3c). Fêmures anteriores robustos e muito maiores do que os médios e posteriores. Tíbias anteriores muito grossas com o extremo distal curvado para dentro, com uma fileira de dentículos muito fortes na face interna (Figura 3e) Naupactus curtus Boheman (Figura 1d)

4' - Pronoto subcilíndrico com a superfície dorsal plana ou levemente convexa. Fêmures anteriores pouco maiores do que os médios e posteriores. Tíbias anteriores delgadas e levemente curvadas internamente no extremo apical sem dentículos ou com uma fileira de dentículos na face interna (Figura 3d) 5

5 - Pronoto quase tão comprido quanto largo. Élitros alongados e estreitos (naviculares) com um par de tubérculos terminais pequenos.

Naupactus navicularis Boheman (Figura 1e)

5' - Pronoto geralmente mais curto do que largo. Élitros ovais sem tubérculos terminais 6

6 - Antenas longas. "Ombros" desenvolvidos. Asas presentes ou não ........................... 7

$6^{\prime}$ - Antenas medianas ou curtas. "Ombros" não desenvolvidos. Asas ausentes ................ 10

7 - Revestimento castanho com manchas esverdeadas iridiscentes. Pronoto com dois pares de manchas. Élitros com três pares de manchas esverdeadas iridiscentes e uma mancha na sutura elitral. Asas metatorácicas desenvolvidas. Espinho das tíbias anteriores (mucro) muito desenvolvido Naupactus bellus Boheman (Figura 1f) 
$7^{\prime}$ - Revestimento verde ou cinza, uniforme ou com um par de listras laterais mais claras no pronoto e nos élitros. Espinho (mucro) pouco desenvolvido 8

8 - Élitros não deprimidos, com a base levemente sinuosa. Escapo antenal não ultrapassa a borda posterior do olho Naupactus virens Boheman (Figura 1g)

$8^{\prime}$ - Élitros deprimidos, com a base reta. Escapo antenal ultrapassa a borda posterior do olho

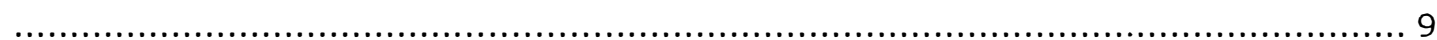

9 - Revestimento escuro sem um par de listras mais claras nas laterais. Pronoto aproximadamente 1,5 mais largo que comprido. Élitros aproximadamente 1,5 vezes mais comprido do que largo ......................... Naupactus versatilis Hustache (Figura $1 \mathrm{~h}$ )

9' - Revestimento escuro com um par de listras mais claras nas laterais. Pronoto aproximadamente 1,2 mais largo que comprido. Élitros aproximadamente 1,8 vezes mais comprido do que largo Naupactus decorus (Fabricius) (Figura 2a)

10 - Extremo distal das tíbias posteriores dilatado, com corbícula ampla e fendida no meio. Revestimento muito denso. Antenas muito curtas, com os antenitos funiculares 1 e 2 subiguais e os seguintes tão compridos quanto largos

Symmathetes kollari Schoenherr (Figura 2b)

10' - Extremo distal das tíbias posteriores não dilatado, corbícula ausente ou muito estreita. Revestimento pouco denso. Antenas curtas, com o antenito funicular 2 igual ou pouco maior que o 1 e os seguintes mais compridos que largos

11 - Coxas anteriores separadas. Corbículas estreitas

Parapantomorus fluctuosus (Boheman) (Figura 2c)

$11^{\prime}$ - Coxas anteriores contíguas. Corbículas ausentes 
12 - Pronoto muito convexo lateralmente. Élitros curtos e globosos. Pronoto com uma listra castanho escura no centro e élitros com listras castanho escuras transversais, na metade e no ápice. Setas eretas em toda a superfície do pronoto e dos élitros

Naupactus ambiguus Boheman (Figura 2d)

$12^{\prime}$ - Pronoto levemente convexo lateralmente. Élitros ovais alongados. Pronoto sem uma listra castanho escura central; élitros sem listras castanho escuras transversais

13 - Revestimento castanho uniforme, com um par de listras castanho nas laterais do pronoto e um par de listras oblíquas brancas nas laterais dos élitros

Naupactus cervinus Boheman (Figura 2e)

13' - Revestimento castanho não uniforme, com uma listra branca longitudinal no centro do pronoto, prolongada sobre a sutura elitral .... Naupactus cinerosus Boheman (Figura 2f)

\subsubsection{Caracterização das espécies de Curculionidae - Naupactini}

\section{1 - Naupactus ambiguus Boheman}

Naupactus ambiguus Boheman 1840

Asynonychus postfasciatus Hustache 1947

Pantomorus postfasciatus, Wibmer \& O'Brien, 1986

Fêmea (Figura 2d) com comprimento de 6 a $9 \mathrm{~mm}$. Revestimento do pronoto + élitros denso, composto de escamas com manchas castanho escuras próximas aos "ombros", na parte mediana e no ápice dos élitros. Setas eretas em toda a superfície do pronoto e élitros. Cabeça: olhos medianamente convexos; antenas medianas com o antenito 2 aproximadamente duas vezes maior que o antenito 1; clava oval. Pronoto: muito convexo lateralmente. Asas: élitros curtos e globosos com base reta; "ombros" ausentes. Asas metatorácicas não desenvolvidas. Pernas: coxas anteriores contíguas; tíbias anteriores com 
uma fileira de dentículos na face interna. Ovipositor: com estilos terminais; hemiesternitos em forma de placa e pouco esclerosados (Figura $3 \mathrm{~h}$ ).

\section{2 - Naupactus bellus Boheman}

Fêmea (Figura 1f) com comprimento de 12 a $14 \mathrm{~mm}$. Tegumento castanho escuro coberto por escamas arredondadas ou alongadas castanhas e azul-esverdeadas iridiscentes nas manchas. Pronoto com duas manchas azul-esverdeadas iridiscentes na margem anterior e duas da parte mediana até a borda posterior. Élitros com sete manchas azul-esverdeadas iridiscentes, quatro nas interestrias 1 a 4 e três a partir da interestria 5. Cabecaa: olhos convexos; antenas longas com o antenito 2 aproximadamente duas vezes maior que o antenito 1; clava fusiforme. Pronoto: subcilíndrico com as margens anterior e posterior curvadas. Asas: élitros ovais com base moderadamente sinuosa e estrias marcadas; "ombros" moderadamente proeminentes. Asas metatorácicas desenvolvidas. Pernas: coxas anteriores contíguas; tíbias anteriores com uma fileira de espinhos na face interna e um espinho longo (mucro) na extremidade distal. Ovipositor: com estilos terminais; hemiesternitos em forma de placa e pouco esclerosados (Figura $3 \mathrm{~h}$ ).

\section{3 - Naupactus cervinus Boheman}

Naupactus cervinus Boheman 1840

Asynonychus godmani Crotch 1867

Aramigus fulleri Horn 1876

Naupactus simplex Pascoe 1881

Pantomorus olindae Perkins 1900

Fêmea (Figura 2e) com comprimento de 7 a $9 \mathrm{~mm}$. Revestimento do pronoto + élitros de coloração castanho com duas manchas brancas oblíquas medianas. Duas manchas laterais castanhas mais claras no pronoto. Setas levemente eretas no ápice elitral. Cabeca: olhos medianamente convexos; antenas longas com o antenito 2 aproximadamente 1,5 vezes maior que o antenito 1 ; clava oval. Pronoto: subcilíndrico com as laterais curvadas. Asas: 
élitros ovais com base reta; "ombros" ausentes. Asas metatorácicas não desenvolvidas. Pernas: coxas anteriores contíguas; tíbias anteriores com uma fileira de dentículos na sua face interna. Ovipositor: com estilos terminais; hemiesternitos em forma de placa e pouco esclerosados (Figura 3h).

\section{4 - Naupactus cinerosus Boheman}

Pantomorus cinerosus Boheman 1833

Naupactus marginalis Boheman 1833

Pantomorus parsevali Costa-Lima 1936

Pantomorus inimicus Marshal 1938

Pantomorus subbimaculatus Hustache 1947

Pantomorus roseomicans Hustache 1947

Pantomorus ursius Kuschel 1955

Fêmea (Figura 2f) com comprimento de 7 a $9 \mathrm{~mm}$. Revestimento de coloração cinza ou castanho claro; pronoto com uma mancha mediana estreita e um par de manchas irregulares laterais, largas, castanho claras; élitros com as laterais predominantemente castanho claros e uma mancha mediana irregular, larga e castanho clara. Cabeça: rostro com carenas muito marcadas; olhos convexos; antenas medianas com 0 antenito 2 aproximadamente 1,5 vezes maior que o antenito 1 ; clava fusiforme. Pronoto: subcilíndrico muito estreito e alongado com as laterais curvadas. Asas: élitros ovais com a base reta; "ombros" ausentes. Asas metatorácicas não desenvolvidas. Pernas: coxas anteriores contíguas; tíbias anteriores com uma fileira de dentículos na face interna. Ovipositor: com estilos terminais; hemiesternitos em forma de placa e pouco esclerosados.

\section{5 - Naupactus curtus Boheman}

Naupactus curtus Boheman 1833

Naupactus unicolor Boheman 1833 
Fêmea (Figura 1d) com comprimento de 10 a $12 \mathrm{~mm}$. Tegumento coberto por escamas esbranquiçadas pouco densas. Listra sutural esbranquiçada que se prolonga no pronoto. Duas listras laterais da base ao ápice do élitro, que se projetam obliquamente para cima, de coloração esbranquiçada. Cabeca: olhos medianamente convexos; antenas longas com o antenito 2 aproximadamente duas vezes maior que o antenito 1; clava oval. Pronoto: subcilíndrico, globoso e muito convexo dorsalmente (Figura 3c). Asas: élitros ovais com base reta; "ombros" ausentes. Asas metatorácicas não desenvolvidas. Pernas: coxas anteriores contíguas; fêmures anteriores robustos e muito maiores do que os médios e posteriores. Tíbias anteriores muito grossas e curvadas para dentro no extremo terminal, com uma fileira de dentículos muito fortes na face interna (Figura 3e); corbículas delgadas. Ovipositor: com estilos terminais; hemiesternitos em forma de placa e pouco esclerosados (Figura $3 \mathrm{~h}$ ).

\section{6 - Naupactus decorus (Fabricius)}

Curculio decorus Olivier 1775

Leptocerus decorus Germar 1824

Fêmea (Figura 2a) com comprimento de 10 a $13 \mathrm{~mm}$. Tegumento preto coberto com revestimento pouco denso formado de escamas delgadas ou alongadas e setas microscópicas de coloração acinzentada ou cobre. Pronoto com duas listras longitudinais de coloração castanho claro nas laterais. Cabeca: olhos medianamente convexos; antenas longas com o antenito 2 aproximadamente duas vezes maior que o antenito 1 ; clava fusiforme. Pronoto: subcilindrico. Asas: élitros ovais com base moderadamente sinuosa; "ombros" pouco proeminentes. Asas metatorácicas não desenvolvidas. Pernas: coxas anteriores contíguas; tíbias anteriores com uma fileira de espinhos na face interna; corbículas ausentes. Ovipositor: com estilos terminais; hemiesternitos em forma de placa e pouco esclerosados (Figura $3 \mathrm{~h}$ ).

\section{7 - Naupactus navicularis Boheman}

Fêmea (Figura 1e) com comprimento de 10 a $13 \mathrm{~mm}$. Revestimento denso, castanho rosado iridiscente, com escamas arredondadas, brancas, amarelas e castanho 
esverdeadas. Listras longitudinais branco-amareladas que se prolongam no pronoto. Mancha mediana glabra no pronoto. Cabeça: olhos muito convexos; antenas medianas com o antenito 2 aproximadamente duas vezes maior que o antenito 1 ; clava oval. Pronoto: subcilíndrico e tão comprido quanto largo. Asas: élitros com base reta e "ombros" reduzidos, ovais e estreitos, com um par de tubérculos terminais pequenos. Asas metatorácicas não desenvolvidas. Pernas: coxas anteriores contíguas; tíbias anteriores com uma fileira de dentículos pequenos na face interna; corbículas presentes. Ovipositor: com estilos terminais; hemiesternitos em forma de placa e pouco esclerosados (Figura $3 \mathrm{~h}$ ).

\section{8 - Naupactus rivulosus (Olivier)}

Curculio rivulosus Olivier 1790

Naupactus rivulosus Dejean 1821

Fêmea (Figura 1b) com comprimento de 15 a $23 \mathrm{~mm}$. Revestimento do pronoto + élitros praticamente glabro, com listras de coloração vermelha, amarela, laranja ou esverdeada, compostas de escamas. Élitros com listras longitudinais sobre as interestrias 2 e 4, unidas na base e listras curtas entre as interestrias 8 a 10. Cabeca: olhos muito convexos; antenas longas com o antenito 2 aproximadamente duas vezes maior que o antenito 1 ; clava fusiforme. Pronoto: subtrapezoidal com laterais curvadas com um sulco mediano longitudinal e uma listra mediana longitudinal e listras transversais anterior e posterior interrompidas. Asas: élitros ovais e alongados com base bisinuada; "ombros" muito salientes. Asas metatorácicas desenvolvidas. Pernas: coxas anteriores contíguas; dentículos reduzidos na face interior do primeiro par de tíbias; corbículas presentes no terceiro par de tíbias. Ovipositor: com estilos terminais; hemiesternitos em forma de placa e pouco esclerosados (Figura 3h).

\section{9 - Naupactus tarsalis Boheman}

Naupactus tarsalis Boheman 1840

Naupactus albidiventris Hustache 1947 
Naupactus glaucivittatus Blanchard 1847

Fêmea (Figura 1c) com comprimento de 15 a $18 \mathrm{~mm}$. Tegumento preto praticamente glabro, coberto por escamas e setas microscópicas esbranquiçadas. Pronoto + élitros com um par de listras com escamas, de coloração branca ou verde iridiscente, com ou sem pulverulência amarela nas laterais e nas interestrias 4 a 6 . Cabeca: olhos levemente convexos; antenas longas com o antenito 2 aproximadamente duas vezes maior que o antenito 1; clava fusiforme. Pronoto: subtrapezoidal com laterais curvadas. Asas: élitros ovais e alongados com base bisinuada; "ombros" muito salientes. Asas metatorácicas desenvolvidas. Pernas: coxas anteriores contiguas; dentículos reduzidos na face interior do primeiro par de tíbias; corbículas não definidas (difusa). Ovipositor: com estilos terminais; hemiesternitos em forma de placa e pouco esclerosados (Figura 3h).

\section{0 - Naupactus versatilis Hustache}

Fêmea (Figura 1h) comprimento de 10 a $12 \mathrm{~mm}$. Tegumento preto coberto com revestimento pouco denso composto de escamas delgadas ou alongadas e setas microscópicas de coloração acinzentada, cobre ou esverdeada. Cabeça: olhos medianamente convexos; antenas longas com o antenito 2 aproximadamente duas vezes maior que o antenito 1; clava fusiforme. Pronoto: subcilindrico. Asas: élitros ovais com base moderadamente sinuosa; "ombros" moderadamente proeminentes. Asas metatorácicas não desenvolvidas. Pernas: coxas anteriores juntas; tíbias anteriores com uma fileira de espinhos na face interna; corbículas ausentes. Ovipositor: com estilos terminais; hemiesternitos em forma de placa e pouco esclerosados (Figura $3 \mathrm{~h}$ ).

\section{1 - Naupactus virens Boheman}

Fêmea (Figura 1g) com comprimento de 13 a $16 \mathrm{~mm}$. Tegumento preto coberto com revestimento verde claro, pouco denso, composto de escamas. Parte mediana da cabeça (sulco) preta sem escamas; laterais do pronoto sem revestimento; listras pretas nas laterais dos élitros, da base até o ápice; interestrias próximas à sutura elitral com 
revestimento pouco denso ou nuas, de cor preta. Cabeca: olhos medianamente convexos; antenas medianas com o antenito 2 aproximadamente duas vezes maior que o antenito 1 ; clava fusiforme. Pronoto: subcilíndrico com a margem posterior curvada. Asas: élitros deprimidos com a base moderadamente sinuosa e estrias marcadas; "ombros" moderadamente proeminentes. Asas metatorácicas desenvolvidas. Pernas: coxas anteriores contíguas; tíbias anteriores sem espinhos; corbículas ausentes. Ovipositor: com estilos terminais; hemiesternitos em forma de placa e pouco esclerosados (Figura $3 \mathrm{~h}$ ).

\section{2 - Teratopactus nodicollis (Boheman)}

Naupactus perpastus Boheman 1840

Teratopactus perpastus Kuschel in Wibmer \& O'Brien, 1986

Fêmea (Figura 1a) com comprimento de 13 a 20 mm. Revestimento do pronoto + élitros castanho ou acinzentado com uma mancha difusa em cada lado do pronoto e dos élitros; interestrias glabras. Cabeca: olhos convexos (Figura 3b); antenas longas com o antenito 2 aproximadamente três vezes maior que o antenito 1 ; clava fusiforme. Pronoto: subcilíndrico com um par de tubérculos medianos laterais. Asas: élitros ovais e alongados com base reta; "ombros" salientes com um par de tubérculos dentiformes. Asas metatorácicas não desenvolvidas. Pernas: coxas anteriores separadas; dentículos desenvolvidos na face interior dos três pares de tíbias e muito desenvolvidos no primeiro par; corbículas presentes no terceiro par de tíbias. Ovipositor: sem estilos terminais e com hemiesternitos em forma de unha e fortemente esclerosados (Figura 3i).

\section{3 - Parapantomorus fluctuosus (Boheman)}

Naupactus fluctuosus Boheman 1840

Pseudopantomorus sharpi Heller 1921

Parapantomorus sharpi, Emden 1936

Parapantomorus fluctuosus, Hustache 1947 
Fêmea (Figura 2c) com comprimento de 7 a $9 \mathrm{~mm}$. Revestimento denso composto de escamas e setas escamiformes de coloração castanha. Duas listras laterais no pronoto e três listras transversais de coloração castanho claro na base na parte mediana e no ápice dos élitros. Cabeca: olhos medianamente convexos (Figura 3b); antenas medianas com o antenito 2 aproximadamente duas vezes maior que o antenito 1 ; clava oval. Pronoto: subcilíndrico. Asas: élitros ovais com base reta; "ombros" ausentes. Asas metatorácicas não desenvolvidas. Pernas: coxas anteriores separadas (Figura $3 \mathrm{~g}$ ); tíbias anteriores com uma fileira de dentículos na face interna. Ovipositor: com estilos terminais; hemiesternitos em forma de placa e pouco esclerosados (Figura $3 \mathrm{~h}$ ).

\section{4 - Symmathetes kollari Schoenherr}

\section{Symmathetes kollari Schoenherr 1847}

Pantomorus kollari Dalla Torre, Emden \& Emden 1936

Fêmea (Figura 2b) com comprimento de 7,5 a $10 \mathrm{~mm}$. Revestimento do pronoto + élitros denso composto de escamas lisas de coloração branca, palha e castanha, poliédricas e contiguamente arranjadas; com estrias bem marcadas. Listras marginais de coloração palha nas interestrias 7 e 8 . Coloração amarela predominante do pronoto ao ápice elitral com uma listra sutural preta cobrindo as interestrias 1 a 3 . Cabeca: olhos medianamente convexos; antenas curtas com os antenitos 1 e 2 subiguais, escapo antenal fortemente dilatado em direção a extremidade; clava globosa. Pronoto: subcilíndrico. Asas: élitros ovais com base reta; "ombros" ausentes. Asas metatorácicas não desenvolvidas. Pernas: coxas anteriores contíguas; tíbias anteriores com uma fileira de dentículos na face interna; extremo distal das tíbias posteriores com pente apical e dorsal separados por uma concavidade pronunciada, pente distal mais saliente que a borda da tíbia (Figura3f). Ovipositor: com estilos terminais; hemiesternitos em forma de placa e pouco esclerosados (Figura 3h). Machos muito menores que as fêmeas, medindo $5 \mathrm{~mm}$ aproximadamente. 

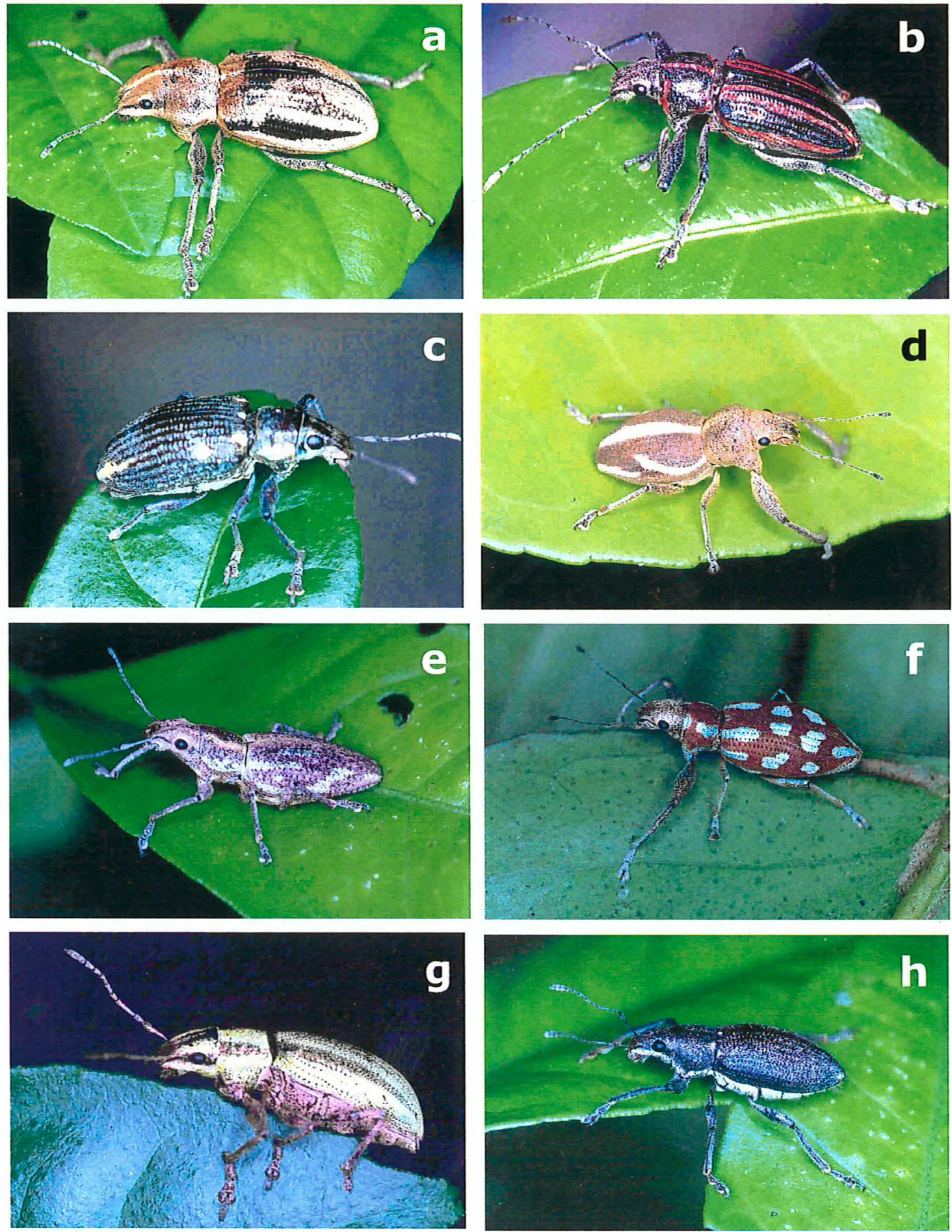

Figura 1 - Vista dorsal dos adultos dos curculionídeos-das-raízes dos citros: a) Teratopactus nodicollis; b) Naupactus rivulosus; c) Naupactus tarsalis; d) Naupactus curtus; e) Naupactus navicularis; f) Naupactus bellus; g) Naupactus virens e h) Naupactus versatilis. 

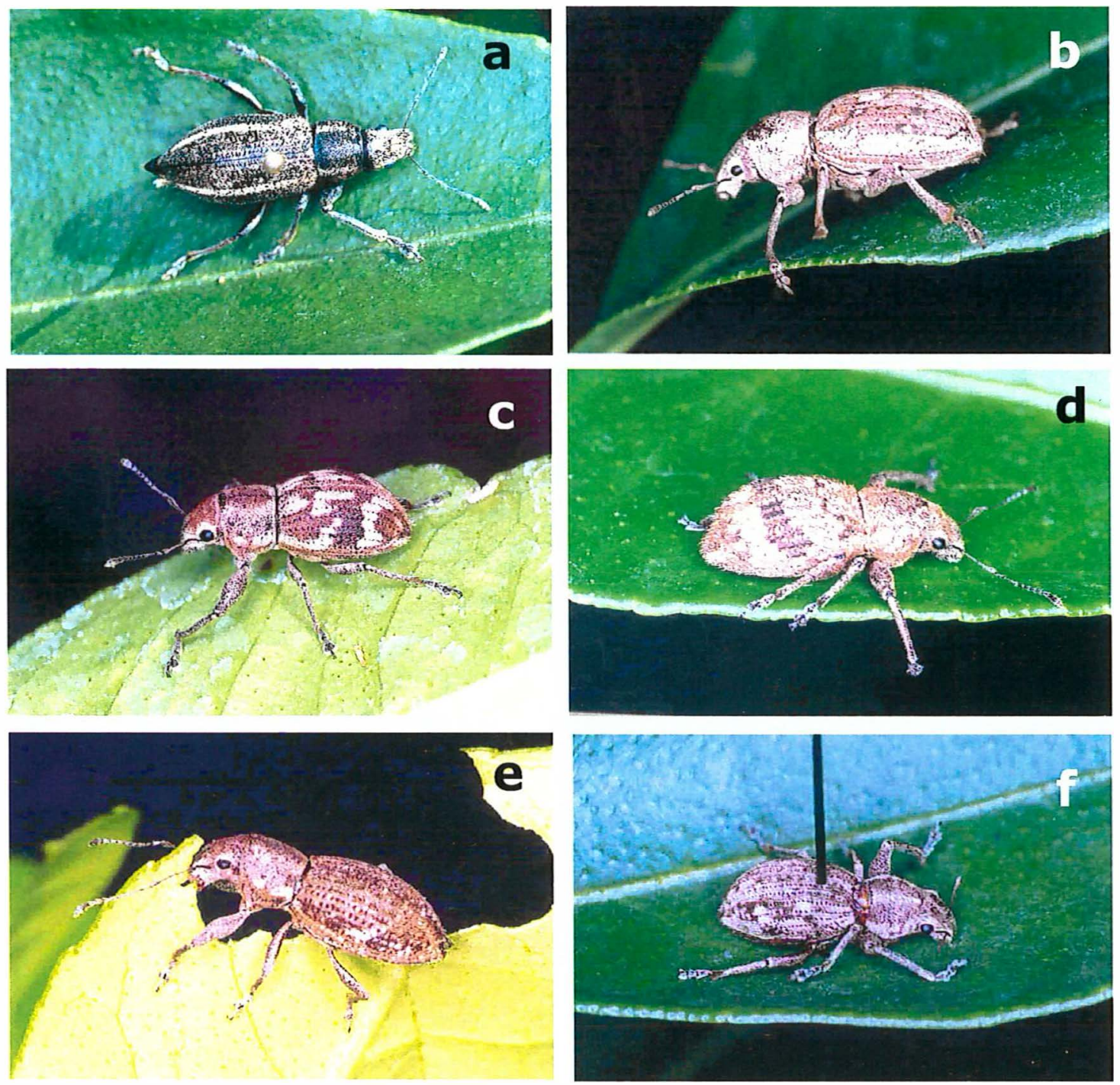

Figura 2 - Vista dorsal dos adultos dos curculionídeos-das-raízes dos citros: a) Naupactus decorus; b) Symmathetes kollari; c) Parapantomorus fluctuosus; d) Naupactus ambiguus; e) Naupactus cervinus e f) Naupactus cinerosus. 

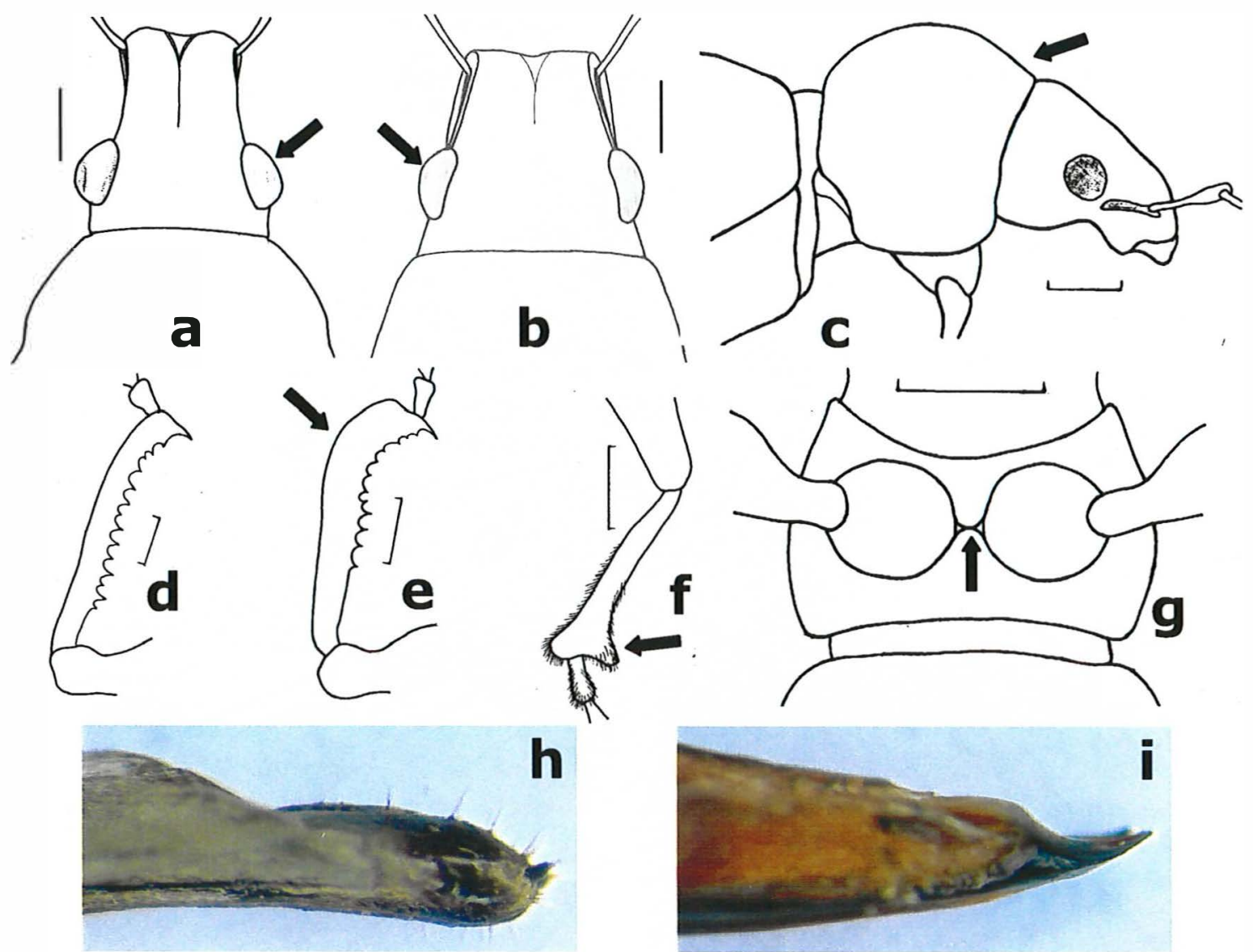

Figura 3 - a) Olhos muito convexos, Naupactus tarsalis; b) Olhos medianamente convexos, Teratopactus nodicollis; c) Pronoto globoso muito convexo dorsalmente, Naupactus curtus; d) Tíbia com linha de dentículos na superfície interna e pouco curvada, Naupactus virens; e) Tíbia com linha de dentículos muito fortes e curvada na extremidade distal, Naupactus curtus; f) Extremidade dilatada do terceiro par de tíbias, Simmathetes kollari; g) Coxas anteriores separadas, Parapantomorus fluctuosus; h) Ovipositor com estilos terminais e hemiesternitos pouco esclerosados, Naupactus sp.; i) Ovipositor sem estilos terminais com hemiesternitos esclerosados em forma de unha, Teratopactus nodicollis. (Escala $1 \mathrm{~mm})$.

\subsubsection{Ocorrência e distribuição de espécies de curculionídeos-das-raízes dos citros}

Dentre as 14 espécies de curculionídeos-das-raízes dos citros verificadas nas regiões citrícolas de São Paulo e Minas Gerais, N. tarsalis, P. fluctuosus e N. versatilis 
ocorreram em maior número de municípios, sendo verificadas em respectivamente 24,23 e 14 localidades da área avaliada. Um segundo agrupamento de espécies ocorreu de quatro a seis localidades da área amostrada, representado pelas espécies $N$. ambiguus, N. bellus, $N$. cervinus, $N$. decorus, $N$. rivulosus, $T$. nodicollis e $S$. kollari, além do grupo composto pelas espécies: $\boldsymbol{N}$. cinerosus, $\boldsymbol{N}$. curtus, $\boldsymbol{N}$. navicularis e $\boldsymbol{N}$. virens, que foram verificadas em apenas dois ou três municípios (Figura 4). A ocorrência de uma espécie em um maior número de municípios possivelmente indique sua maior capacidade de adaptação edáfica e climática, como verificado para $N$. tarsalis, $P$. fluctuosus e $N$. versatilis, sem garantir no entanto que uma dada espécie seja mais importante para a cultura, por ser mais freqüente. Dentre as três espécies mencionadas, $P$. fluctuosus e $N$. versatilis apresentam populações partenogenéticas, característica atribuída por Lanteri \& Normark (1995) para o sucesso que as espécies sul-americanas de Naupactini tiveram ao colonizar outros continentes. A ocorrência de espécies com reprodução partenogenética, em diferentes locais da área estudada, pode explicar a maior capacidade de distribuição das mesmas, pois no grupo com ocorrência em quatro a seis localidades estão as demais espécies com essa característica reprodutiva.

Os curculionídeos-das-raízes dos citros foram encontrados em 32 dos 33 municípios amostrados. Não foram encontrados Naupactini em Uberaba, MG, embora tenham sido verificados danos nas folhas, sendo relatada sua ocorrência na região, por informações de técnicos e por Pinto et al. (1996) que verificaram a ocorrência de $T$. nodicollis, $P$. fluctuosus, $N$. rivulosus e $N$. tarsalis em Comendador Gomes, município vizinho aos amostrados, na presente pesquisa, no Triângulo Mineiro. A observação visual dos Naupactini nos pomares cítricos, pelo agricultor, somente se dá em anos com níveis populacionais elevados, que possivelmente esteja relacionado às práticas de controle adotadas para outras pragas, bem como às condições climáticas favoráveis, por anos seguidos. O uso de pano-debatida, entretanto, é capaz de detectar pequenas populações dos curculionídeos-das-raízes, mesmo em épocas de baixa ocorrência. Pode-se inferir, portanto, que os curculionídeos-dasraízes ocorrem em praticamente toda a área cultivada com citros nos estados de São Paulo e 
parte do Triângulo Mineiro, em Minas Gerais (Figura 4), confirmando constatação feita por Guedes et al. (2002) que levantaram a ocorrência dos curculionídeos-das-raízes através de um questionário enviado e respondido por técnicos e citricultores das diferentes regiões citrícolas dos estados de São Paulo e Minas Gerais.

Da área citrícola estudada, as regiões centro e sul do estado de São Paulo apresentaram maior número de espécies de curculionídeos-das-raizes, em relação à região norte do estado de São Paulo e parte do Triângulo Mineiro, em Minas Gerais. Dentre os municípios com maior diversidade de curculionídeos-das-raízes, destacaram-se Ribeirão Bonito, Itapetininga, Américo Brasiliense, Santa Rita do Passa Quatro, Piracicaba e Guarantã, todos com mais de cinco espécies por localidade (Figura 5). A maior diversidade de espécies de Naupactini nesses locais, pode estar relacionada a vários fatores não estudados; entretanto, é provável que condições climáticas com temperaturas mais amenas e chuvas mais bem distribuídas, o menor tempo de cultivo de citros e a maior diversidade de hospedeiros nativos ainda existente, tenha favorecido a sobrevivência de um maior número de espécies, presentes nesses locais antes da expansão do cultivo de citros.

Por sua vez, o controle químico adotado visando a redução desses curculionídeos e de outras espécies-praga, pode ter diminuído as populações e a sua diversidade; a redução dos inimigos naturais com produtos químicos não seletivos, pode ter favorecido o crescimento populacional de espécies mais tolerantes ou com aspectos comportamentais e/ou fisiológicos beneficiados pelas práticas de controle. O comportamento de variedades e de porta-enxertos com relação aos curculionídeos devem ser pesquisados.

A ocorrência de várias espécies de curculionídeos-das-raízes em um mesmo local, possivelmente não indique relação entre elas e sim, seja um reflexo da capacidade dessas espécies sobreviverem nas distintas sucessões culturais verificadas nas últimas décadas nas regiões atualmente cultivadas com citros. Outra hipótese para a ocorrência desse grupo de insetos nos citros, é que eles tenham se mantido próximos aos cultivos, em matas e/ou áreas marginais não cultivadas e que com a introdução de citros tenham recolonizado as áreas e aumentando seus níveis populacionais. 
Os curculionídeos-das-raízes pertencentes a Tribo Naupactini foram encontrados em todas as regiões amostradas, indicando sua ampla distribuição na área cultivada com citros nos estados de São Paulo e Minas Gerais. A maioria das espécies pertence ao gênero Naupactus, que junto com Parapantomorus, ocorreu em maior número de localidades, caracterizando a adaptação das espécies à cultura e seu sucesso na colonização em citros. Esses aspectos, associados à reprodução partenogenética de $\boldsymbol{N}$. versatilis e $P$. fluctuosus permitem inferir que essas espécies apresentam maior potencial de tornarem-se pragas ainda mais importantes de citros.

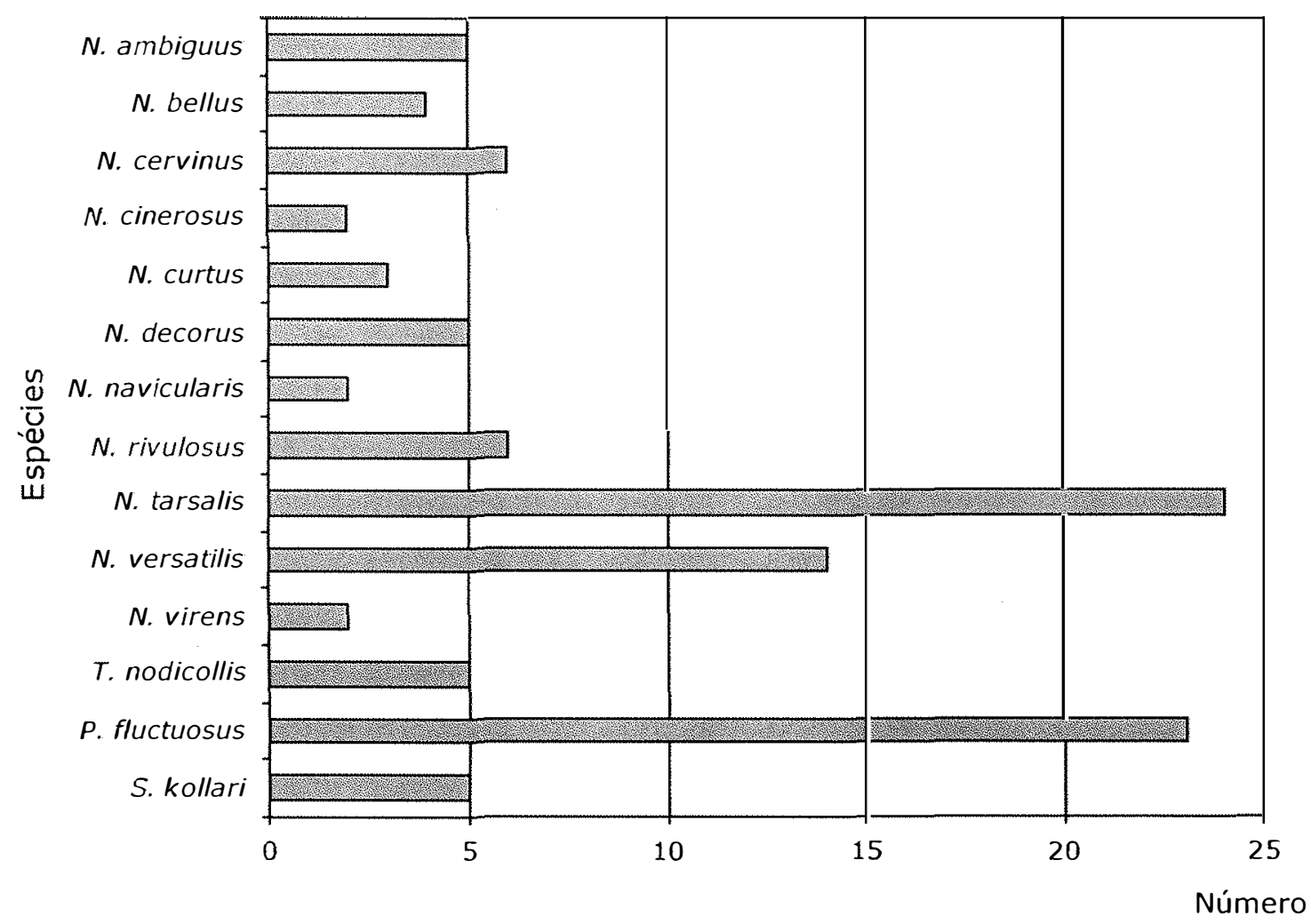

Figura 4 - Municípios com ocorrência de espécies de curculionídeos-das-raízes da área citrícola dos estados de São Paulo e Minas Gerais, em levantamento realizado em 2001/02. 


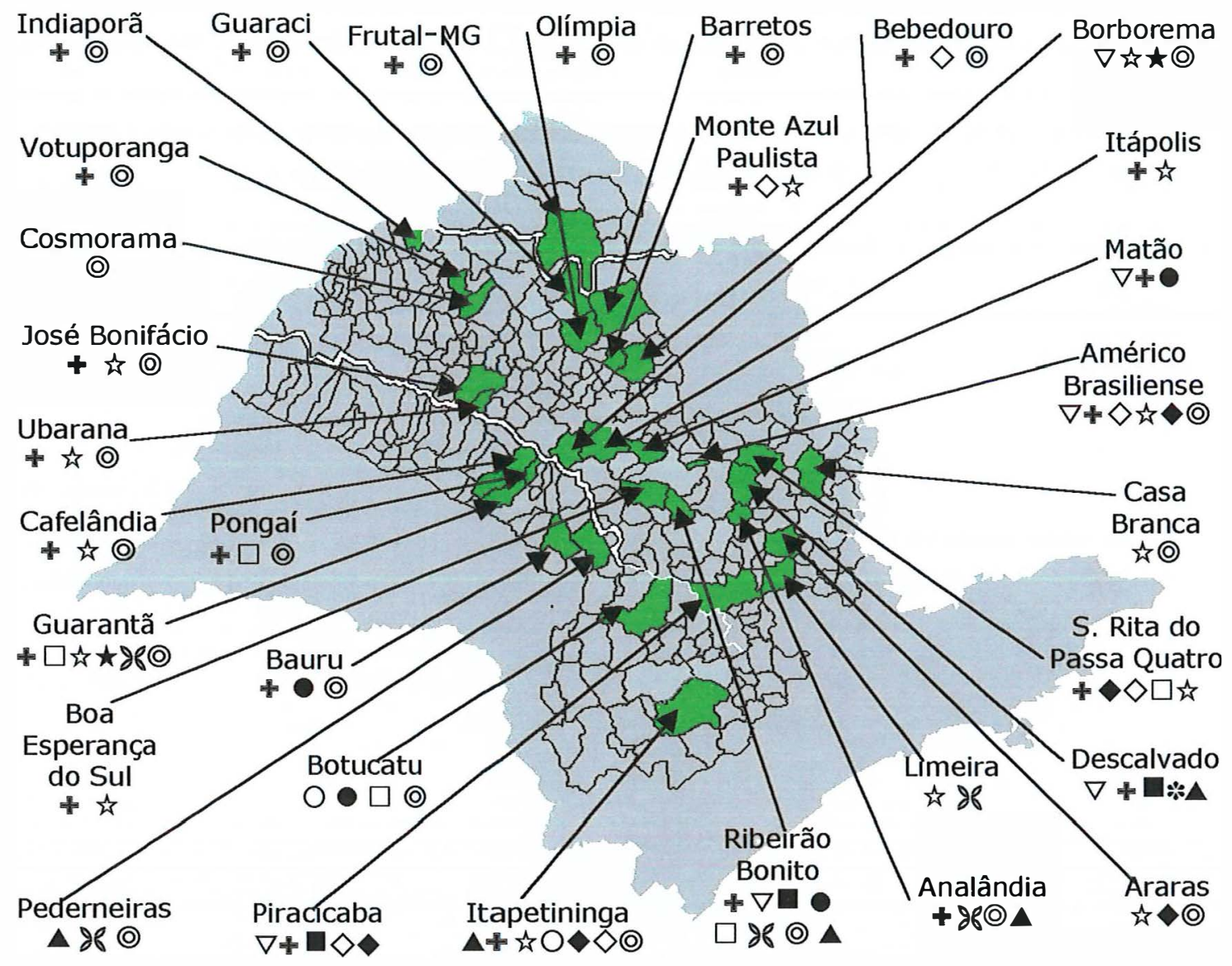

Haupactus versatilis

O Naupactus navicularis

- Naupactus ambiguus

$\diamond$ Naupactus cervinus

$\star$ Naupactus cinerosus

\& Simmathetes kollari

() Parapantomorus fluctuosus

Figura 5 - Distribuição das espécies de curculionídeos-das-raízes nos municípios da área citrícola dos estados de São Paulo e Minas Gerais, em levantamento realizado em 2001/02.

\subsection{Conclusões}

- São registradas quatorze espécies de Naupactini em citrus nos estados de São Paulo e Minas Gerais, Brasil. Onze pertencem ao gênero Naupactus Dejean, sendo elas, 
Naupactus ambiguus Boheman, Naupactus bellus Boheman, Naupactus cervinus Boheman, Naupactus cinerosus Boheman; Naupactus curtus Boheman, Naupactus decorus (Fabricius), Naupactus navicularis Boheman, Naupactus rivulosus (Olivier), Naupactus tarsalis Boheman, Naupactus versatilis Hustache e Naupactus virens Boheman; uma ao gênero Teratopactus Heller, Teratopactus nodicollis (Boheman); uma ao gênero Parapantomorus Emden, Parapantomorus fluctuosus (Boheman) e uma ao gênero Symmathetes (gênero revalidado), Symmathetes kollari Schoenherr;

- Os curculionídeos-das-raizes são encontrados em todas as regiões citrícolas dos estados de São Paulo e Minas Gerais e apresentam maior diversidade nos municípios da região centro-sul do estado de São Paulo;

- As condições climáticas da região centro-sul do estado de São Paulo, com temperaturas mais amenas e chuvas mais bem distribuidas, podem favorecer a ocorrência e a diversidade dos curculionídeos-das-raízes dos citros;

- N. tarsalis, P. fluctuosus e N. versatilis ocorrem em maior número dos municípios estudados. 


\section{BIOLOGIA DOS CURCULIONÍDEOS-DAS-RAÍZES DOS CITROS}

\section{Resumo}

O objetivo deste trabalho foi estudar algumas caracteristicas das fases de ovo, larva, pupa e adulta de três espécies de curculionídeos-das-raízes dos citros e aspectos da oviposição do grupo. Os insetos foram coletados em citros em Itapetininga, SP, levados ao Laboratório de Biologia de Insetos da ESALQ/USP, em Piracicaba, SP, onde foram mantidas as espécies Naupactus cervinus Boheman, Naupactus versatilis Hustache e Parapantomorus fluctuosus (Boheman), das quais foi avaliada duração e a viabilidade da fase de ovo e calculados o limite térmico inferior de desenvolvimento $(\mathrm{Tb})$ e a constante térmica $(\mathrm{K})$. A oviposição de $N$. cervinus, $N$. versatilis, Naupactus tarsalis Boheman, P. fluctuosus e Teratopactus nodicollis (Boheman) foi estudada em laboratório. A duração do período larvapupa e o número de ínstares larvais de $N$. cervinus e de $N$. versatilis foram avaliados, em telado. Da fase adulta de $N$. cervinus e $N$. versatilis foram avaliados: a longevidade, tempo de alimentação, período de pré-oviposição, oviposição, número de posturas e de ovos, além do consumo de folhas de citros. As espécies de curculionídeos-das-raízes dos citros apresentaram diferenças nas características biológicas, no comportamento de oviposição e no potencial de danificar os citros. A fase de ovo dos Naupactini variou de 13,8 a 40,4 dias dependendo da temperatura e da espécie. Os limiares térmicos inferiores de desenvolvimento dessa fase foram de $8,1,8,3$ e $9,9^{\circ} \mathrm{C}$ com constante térmica foi $397,7,385,7$ e 294,1 graus dia (GD), respectivamente, para $N$. cervinus, $N$. versatilis e $P$. fluctuosus. No laboratório, a oviposição dos curculionídeos-das-raízes dos citros foi feita em frutos, em fendas estreitas, sob o cálice do mesmo, independente da sua cor (estágio de maturação), e também em 
resíduos vegetais e no solo. O porta-enxerto influenciou a duração do período larva-pupa de N. cervinus, que foi de 143 dias em limão cravo e de 200 dias em Citrumelo Swingle. O período larva-pupa de $N$. versatilis foi de 229 dias em limão cravo. O período ovo-adulto de N. cervinus foi de 162 a 240 dias e de 250 a 269 dias para N. versatilis. Ambos as espécies são univoltinas e apresentaram cinco ínstares larvais. A espécie $N$. versatilis é potencialmente mais prejudicial aos citros, pois coloca um número maior de ovos ( 214,6 ovos) do que $N$. cervinus (120,9 ovos), apresenta maior longevidade (30,9 × 25,2 dias) e consome maior área foliar $\left(31,0 \times 15,0 \mathrm{~cm}^{2}\right)$.

\section{Summary}

The goal of this work was to study some characteristics of the egg, larva, pupa and adult stages of three species of citrus root weevils and aspects of the oviposition of the group. The insects were collected from citrus in Itapetininga, SP, taken to the Insect Biology Laboratory of ESALQ/USP, in Piracicaba, SP, keeping species Naupactus cervinus Boheman, Naupactus versatilis Hustache and Parapantomorus fluctuosus (Boheman), of which one evaluated the duration and viability of the egg stage and the lower temperature threshold (Tb) and thermal constant (K). The oviposition of $N$. cervinus, $N$. versatilis, Naupactus tarsalis Boheman, P. fluctuosus and Teratopactus nodicollis (Boheman) was studied in laboratory. The duration of the larva-pupa period and the number of larval instars of $N$. cervinus and $N$. versatilis were evaluated on a screen. Regarding the adult stage of $N$. cervinus and $N$. versatilis one evaluated longevity, feeding time, pre-oviposition period, oviposition, number of egg-laying and eggs, in addition to the consumption of the citrus leaf. The species of citrus root weevils showed different biological characteristics, oviposition behavior and potential to damage the citrus. The Naupactini egg stage ranged from 13.8 to 40.4 days according to temperature and species. The temperature thresholds of this stage

were $8.1,8.3$, and $9.9^{\circ} \mathrm{C}$ at thermal constant of 385.7 and 294.1 degree-days (DD), 
respectively, for $N$. cervinus, $N$. versatilis and $P$. fluctuosus. In the laboratory the oviposition of the citrus root weevils occurred in fruit slits, under the fruit calyx, regardless of the color (maturation stage), in plant litter and in the soil. The rootstock influenced the duration of the larva-pupa stage of $N$. cervinus, of 143 days in 'Rangpur' lime and 200 days in Swingle citrumelo. The larva-pupa period of $N$. versatilis took 229 days in 'Rangpur' lime. The eggadult period of $N$. cervinus took 162-240 days and 250-269 days for $N$. versatilis. Both are univoltine species and had five larval instars. Species $N$. versatilis is potentially more injurious to citrus, for it lays a larger number of eggs (214.6 eggs) than $N$. cervinus (120.9 eggs), has a higher longevity (30.9 x 25.2 days) and consumes a larger leaf area (31.0 $\mathrm{x}$ $\left.15.0 \mathrm{~cm}^{2}\right)$.

\subsection{Introdução}

A citricultura é uma das atividades agrícolas da maior importância econômica para a região Sudeste do Brasil, apresentando um excelente nivel de competitividade e levando o país a ser o maior produtor de frutos e o maior exportador mundial de suco concentrado de laranja. A cultura, no entanto, apresenta uma série de problemas fitossanitários, que podem

limitar e comprometer a produção nacional, destacando-se os ácaros e os insetos-praga (Gravena, 1997).

Em algumas regiões produtoras dos estados de São Paulo e de Minas Gerais, os curculionídeos-das-raízes dos citros são considerados pragas primárias da cultura, em virtude dos danos diretos causados pelas larvas ao sistema radicular das plantas e pelos ferimentos que facilitam a entrada de patógenos, tais como Phytophthora spp. (Guedes et al., 2002), causador da gomose.

As espécies de curculionídeos-das-raizes dos citros apresentam ciclos de vida semelhantes (McCoy, 1994). Assim, os adultos recém emergidos, migram para a copa das plantas, onde se alimentam das folhas. As fêmeas ovipositam sob o cálice dos frutos e no solo. As larvas eclodem e se desenvolvem no solo onde consomem radicelas, raízes finas e a 
casca das raízes mais grossas, até passarem à fase de pupa, ainda no solo. A seguir transformam-se em adultos, completando o ciclo anual dos curculionídeos (Gravena et al., 1992; Guedes, 2001).

No entanto, faltam estudos sobre aspectos biológicos dos curculionídeos que ocorrem em citros no Brasil, aspectos essenciais ao manejo racional e econômico desse grupo. Na falta dessas informações, o controle desses insetos é feito de forma inadequada, demandando custos elevados, com resultados pouco satisfatórios e contribuindo para o agravamento do problema, em virtude dos desequilíbrios biológicos causados.

O objetivo do trabalho foi estudar algumas características das fases de ovo, larva, pupa e adulta das principais espécies de curculionídeos-das-raízes dos citros.

\subsection{Material e Métodos}

Os insetos utilizados na criação estoque dos curculionídeos-das-raízes foram coletados em pomares de citros, na Empresa Citrovita, em Itapetininga-SP, com o auxílio de um pano-de-batida $(4,0 \times 4,0 \mathrm{~m})$, em março e abril de 2000 . As fêmeas de Naupactus cervinus Boheman, Naupactus versatilis Hustache e Parapantomorus fluctuosus (Bohemann) foram levadas para o Laboratório de Biologia de Insetos do Departamento de Entomologia, Fitopatologia e Zoologia Agrícola da ESALQ/USP, em Piracicaba-SP, onde foram mantidas em caixas plásticas $(10,0 \times 20,0 \times 30,0 \mathrm{~cm}$ de comprimento, com as laterais teladas) com o fundo revestido com papel de filtro umedecido (Figura 1.a). Para alimentação, diariamente eram fornecidas folhas de citros, após serem limpas, trocando-se e umedecendo-se o papel de filtro do fundo da gaiola. As caixas foram mantidas em uma sala com temperatura de $25 \pm$ $2^{\circ} \mathrm{C}, 60 \pm 20 \%$ de UR e fotofase de 14 horas.

As posturas foram obtidas em um substrato artificial feito com papel, parafinado a quente, cortado em tiras de $9,0 \times 2,5 \mathrm{~cm}$ e dobrado de $1,5 \mathrm{em} 1,5 \mathrm{~cm}$, compondo uma "sanfona" de seis dobras $(1,5 \times 3,0 \mathrm{~cm})$ (Figura 1.b). Essa "sanfona" foi mantida fechada com 
fita crepe e oferecida às fêmeas para oviposição. Cada caixa plástica continha 50 fêmeas e eram oferecidas dez "sanfonas" para cada grupo, por 24 horas. Após esse período, o substrato era retirado das gaiolas e as posturas descoladas da parafina e colocadas numa placa de Petri, contendo sulfato de cobre $\left(\mathrm{CuSO}_{4}\right)$ a $2 \%$ onde eram mantidas por quatro minutos, para descontaminação externa.

No estudo da fase de ovo foram avaliadas as espécies $N$. cervinus, $N$. versatilis e P. fluctuosus. Após a descontaminação externa das posturas, foi realizada a contagem do número de ovos e a seguir foram dispostas em placas de Petri com o fundo coberto com papel de filtro umedecido com água destilada. O experimento foi instalado em delineamento inteiramente casualizado com cinco repetições (placa), sendo que cada placa continha entre 60 e 80 ovos. As placas foram fechadas com uma fita de filme transparente (parafilme ${ }^{\circledR}$ ) e fita adesiva. A seguir foram mantidas em câmaras climatizadas (BOD), reguladas nas temperaturas de $18,20,22,25,28,30$ e $32 \pm 1^{\circ} \mathrm{C}, 80 \pm 10 \%$ de UR e fotofase de 14 horas.

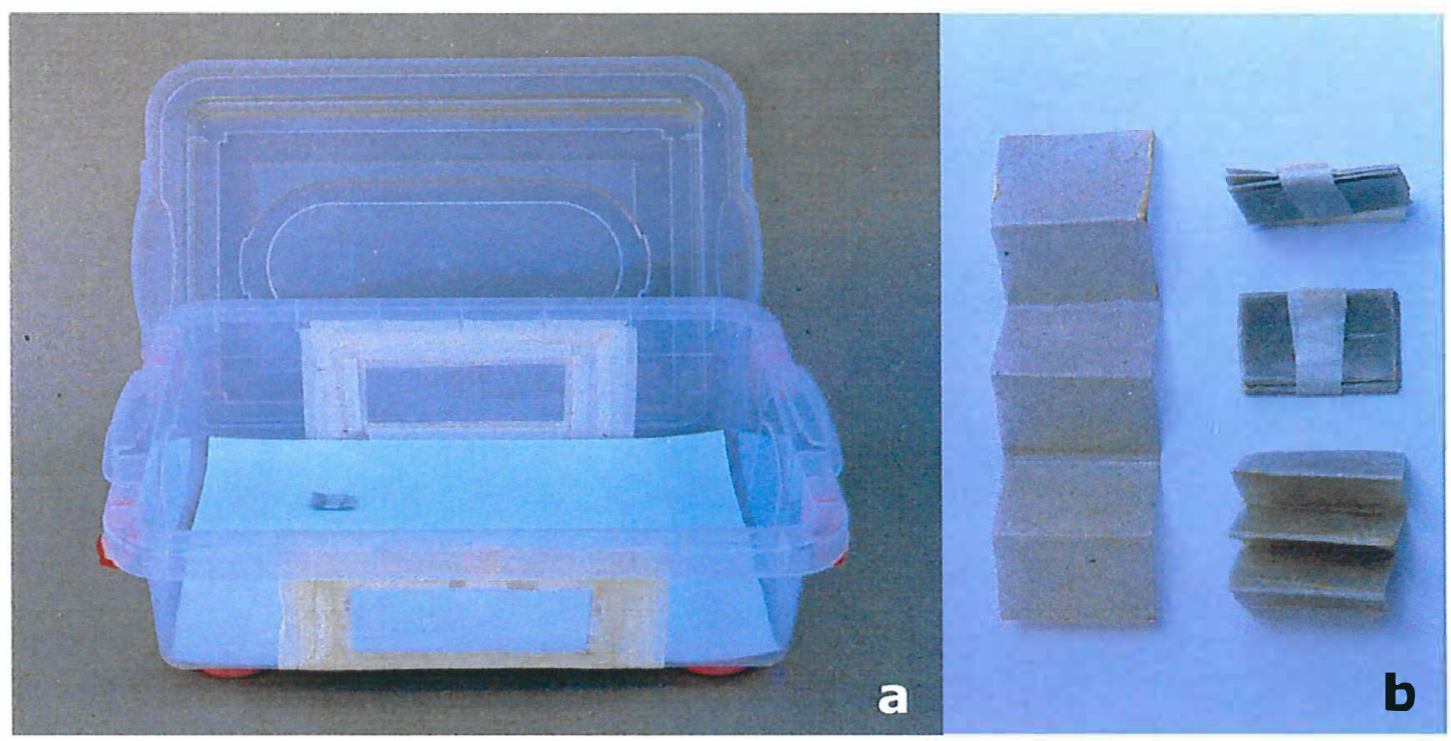

Figura 1 - a) Recipiente para criação dos curculionídeos-das-raízes; b) Substratos de papel parafinado para oviposição ("sanfonas").

Após a início da eclosão das larvas, diariamente foi contado e anotado o número de larvas (para determinação da viabilidade). Com os resultados de duração, foi determinado 
o limite térmico inferior de desenvolvimento ( $\mathrm{Tb}$ ) e a constante térmica $(K)$ para a fase de ovo pelo método da hipérbole (Haddad et al., 1999).

O substrato de oviposição para os curculionídeos-das-raízes dos citros foi estudado no Laboratório de Biologia de Insetos do Departamento de Entomologia, Fitopatologia e Zoologia Agrícola da ESALQ/USP. Foi analisada a oviposição das espécies $N$. cervinus, $N$. versatilis, Naupactus tarsalis Boheman, P. fluctuosus e Teratopactus nodicollis (Boheman). Os insetos e os substratos vegetais utilizados (frutos, folhas, ramos, solo e resíduos) foram coletados em pomares de laranja com 12 anos de idade, em Itapetininga, SP, em março e abril de 2000 (Experimentos A, B, C D1 e D2) e em outubro de 2001 (Experimento E). Nos experimentos de laboratório, as caixas plásticas foram mantidas em câmara climatizada regulada à temperatura de $25 \pm 1^{\circ} \mathrm{C}, 60 \pm 10 \%$ de UR e fotofase de 14 horas.

No Experimento A, com livre escolha, a oviposição de $N$. cervinus e $P$. fluctuosus foi avaliada em folhas (dois grupos de duas folhas sobrepostas, unidas pelo pedúnculo), dois frutos (cada um com cálice e pedúnculo) e duas "sanfonas" de papel parafinado (Figura 1.b), dispostos sobre o fundo da caixa, coberto com papel pardo. Cada repetição constava de uma caixa plástica (Figura 1.a), onde foram colocados 12 insetos de idade desconhecida, por 48 horas.

No Experimento $B$, sem chance de escolha, cada estrutura (Experimento $A$ ) foi coberta com um copo plástico de $10,0 \mathrm{~cm}$ de altura e continha dois insetos com as mesmas características do Experimento A. Ambos os experimentos ( $\mathrm{A}$ e B) foram conduzidos no delineamento inteiramente casualizado, com cinco repetições (Figura 2a).

No Experimento C, com livre escolha, a oviposição de $N$. cervinus, $N$. versatilis e $P$. fluctuosus foi avaliada em frutos de três colorações (verde, verde amarelado e amarelo), dispostos sobre o fundo coberto com papel pardo. As repetições e a avaliação foram idênticas às do Experimento B. Ambos os experimentos foram conduzidos no delineamento inteiramente casualizado com sete repetições.

No Experimento D1, com livre escolha, a oviposição de $N$. cervinus, $N$. versatilis e P. fluctuosus foi avaliada em frutos com três distâncias da casca ao cálice [aderido, 
intermediário $(\leq 1,5 \mathrm{~mm})$ e distante $(\geq 1,5 \mathrm{~mm})$ ], dispostos sobre um fundo de isopor coberto com papel pardo. As repetições e a avaliação foram idênticas às do Experimento A (Figuras 2c, 2d, 2e e 2f). No Experimento D2, sem chance de escolha, foram utilizadas as mesmas metodologias dos Experimento D1 e B2, com sete repetições (Figuras 2c, 2d, 2e e 2g).

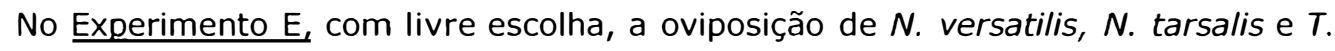
nodicollis foi avaliada em quatro substratos: folha (dois grupos de duas folhas sobrepostas, unidas pelo pedúnculo), dois frutos (cada uma com cálice, pedúnculo e folha), solo umedecido (placa de petri plástica com $6,0 \mathrm{~cm}$ de diâmetro) e resíduos vegetais de gramíneas (placa de petri plástica com $6,0 \mathrm{~cm}$ de diâmetro), dispostos sobre o fundo coberto com papel pardo (Figura 2b). O experimento foi conduzido no delineamento inteiramente casualizado com oito repetições constando de uma caixa plástica (Figura 1a) onde foram colocados 16 insetos de idade desconhecida por 48 horas. Após a exposição, foi feita a contagem dos ovos e análise dos resultados.

O estudo da fase larval dos curculionídeos-das-raízes, visando conhecer a duração e o número de ínstares, foi conduzido em mudas de citros cultivadas em sacos plásticos mantidos em telado. As larvas de $N$. cervinus e de $N$. versatilis, foram obtidas de acordo com o método descrito no estudo da fase de ovo, de posturas coletadas em 07/03/01 e 28/02/01, posteriormente mantidas em câmara climatizada à temperatura de $28 \pm 1^{\circ} \mathrm{C}, 80 \pm 10 \%$ de UR e fotofase de 14 horas. Logo após a eclosão, as larvas foram transferidas para as mudas até a emergência dos adultos. Dessa forma foi possivel determinar o período larva-pupa.

As mudas de limão cravo e Citrumelo Swingle foram obtidas de sementes e inicialmente cultivadas na Empresa Citrovita, em Itapetininga-SP. As plântulas foram transplantadas para sacos plásticos de $2,5 \ell$ contendo solo arenoso, peneirado e adubado, oriundo da área citrícola da fazenda Olho D'Água da referida Empresa. Aos 120 dias após o transplante, as plantas (com 0,50 m de altura, aproximadamente) foram transferidas para uma área telada do setor de Biologia de Insetos do Departamento de Entomologia, Fitopatologia e Zoologia Agrícola da ESALQ/USP, em Piracicaba. No telado, 240 mudas de limão cravo e 120 de Citrumelo Swingle foram infestadas (25 larvas/saco) com larvas de $\mathbf{N}$. 
cervinus em limão cravo e em Citrumelo Swingle (25/03/01), e com larvas de $N$. versatilis em limão cravo (30/03/01). Após a infestação das plantas, os sacos plásticos foram cobertos com plástico transparente (com orifícios para ventilação), para evitar a fuga de adultos, após a emergência. As mudas foram adubadas com solução nutritiva e regularmente irrigadas no transcorrer do experimento.
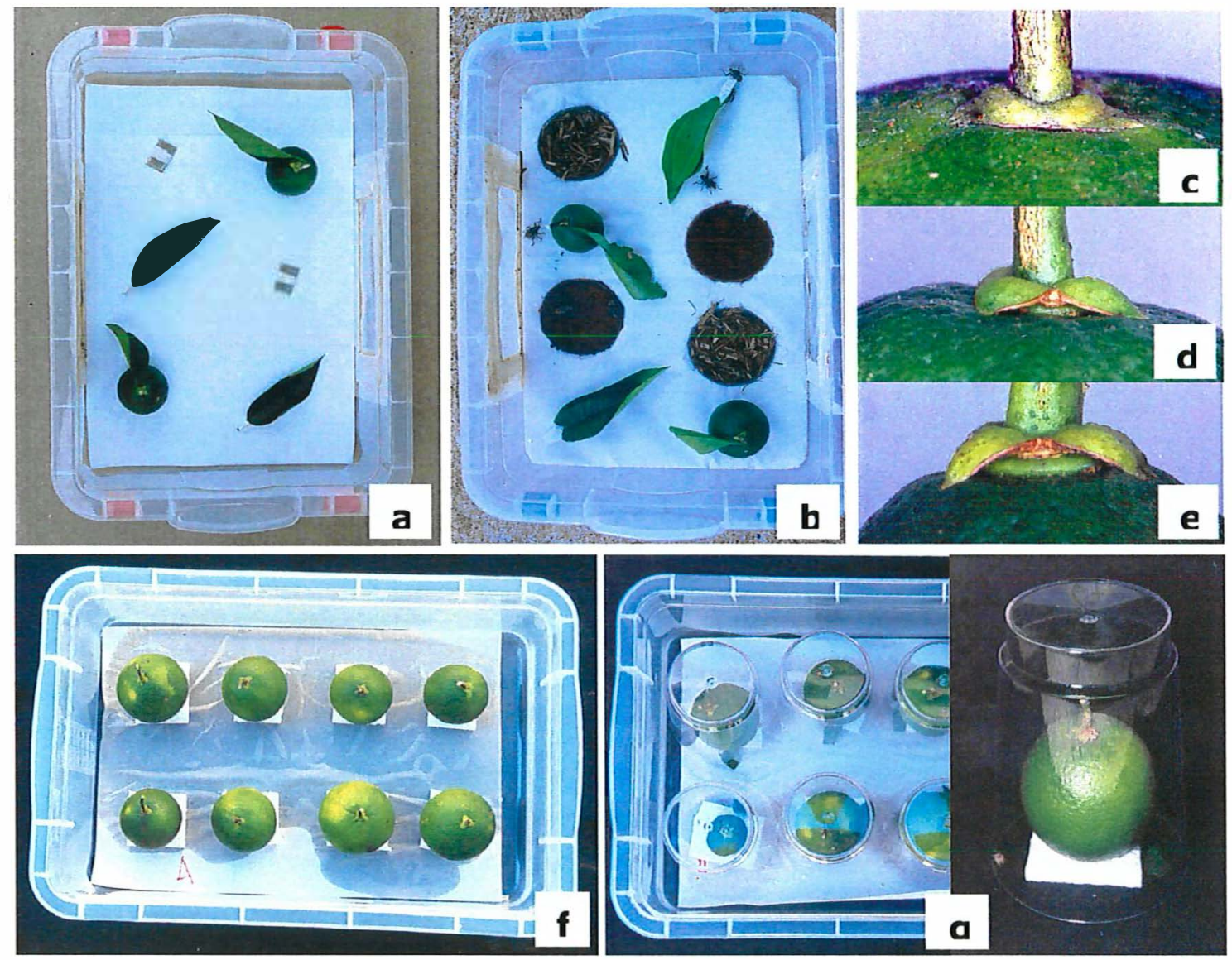

Figura 2 - Recipientes e materiais utilizados no estudo da oviposição dos curculionídeos-dasraízes dos citros em laboratório: a) Experimento $B$, caixa plástica com folhas, frutos e "sanfonas" de papel parafinado b) Experimento $E$, caixa plástica com folhas, frutos, resíduos vegetais e solo c) Cálice aderido, d) Cálice intermediário, e) Cálice distante, f) Experimento D1, caixa plástica com frutos, com chance de escolha g) Experimento D2, caixa plástica com frutos, sem chance de escolha e detalhe do fruto coberto com copo plástico. 
Durante o desenvolvimento do experimento, de abril de 2001 a fevereiro de 2002, quinzenalmente foram separadas cinco amostras de cada um dos três tratamentos e peneiradas três vezes seguidas (peneiras de malha de $2 \mathrm{~mm}$ ). As larvas, pupas e adultos encontrados foram contados. Nessas avaliações, também foi verificada a emergência de adultos nas amostras não peneiradas. As larvas obtidas foram mantidas em álcool $70 \%$; para a medição das cápsulas cefálicas foi utilizada uma ocular micrométrica (Wild MMS 235) acoplada a um microscópio estereoscópico. O número de ínstares foi determinado com a utilização da curva multimodal de freqüências da largura das cápsulas cefálicas, para a formação de hipóteses, que foram testadas no modelo linearizado da regra de Dyar, com auxílio do programa Mobae (Haddad et al., 1995).

Para estudo das características da fase adulta de $N$. cervinus e $N$. versatilis as fêmeas foram coletadas imediatamente após a emergência nas gaiolas de emergência em campo (item 5.2.4) na Empresa Citrovita, em Itapetininga-SP. No mesmo dia, os insetos foram levados ao Laboratório de Biologia de Insetos (ESALQ/USP), onde foram separadas e avaliadas 100 fêmeas de cada espécie. Foram feitas observações da longevidade, tempo de alimentação, período de pré-oviposição, oviposição, número de posturas e total de ovos por fêmea, além do consumo diário e consumo total de folhas de citros. As fêmeas foram individualizadas em placas de plástico de $6,0 \mathrm{~cm}$ de diâmetro, mantidas em câmara climatizada regulada a $25 \pm 1{ }^{\circ} \mathrm{C}$, UR de $80 \pm 10 \%$ e fotofase de 14 horas. Diariamente, até a morte das fêmeas, era fornecido um disco foliar de citros de $1,5 \mathrm{~cm}^{2}$ de diâmetro por placa, substituido a cada 24 horas. O material não consumido foi medido, com um medidor de área foliar (CI-203, marca CID Incorporation), chegando-se à área consumida por diferença, entre a área inicial e final do disco fornecido.

Para a quantificação da oviposição foi fornecida a "sanfona" anteriormente referida (item 4.2), com seis dobras $(1,5 \times 3,0 \mathrm{~cm})$ de papel parafinado, por placa. Esse substrato foi substituído diariamente sendo feita a contagem do número de posturas e de ovos por fêmea. Os dados foram registrados e os resultados submetidos à análise da variância, sendo as médias comparadas pelo teste de Tukey ao nível de $5 \%$ de probabilidade. 


\subsection{Resultados e Discussão}

\subsubsection{Fase de ovo e oviposição em laboratório}

A duração do período embrionário dos curculionídeos-das-raízes dos citros variou com a temperatura e com a espécie estudada, entre 13,8 dias $\left(30\right.$ e $32^{\circ} \mathrm{C}$ ) e 40,4 dias $\left(18^{\circ} \mathrm{C}\right)$ (Tabela 1). Em geral, na faixa de temperaturas entre 18 a $32^{\circ} \mathrm{C}$, as durações da fase de ovo diferiram estatisticamente para cada temperatura. Como esperado, houve um decréscimo do período embrionário para as três espécies, na faixa de estudo. A duração da fase de ovo foi muito semelhante para Naupactus cervinus Boheman e Naupactus versatilis Hustache, nas mesmas temperaturas, embora a primeira espécie não tenha se desenvolvido a 30 e $32^{\circ} \mathrm{C}$, e a segunda apenas a $32^{\circ} \mathrm{C}$. Parapantomorus fluctuosus (Bohemann), por outro lado, apresentou desenvolvimento mais rápido do que Naupactus spp., em todas as temperaturas testadas. Se a tendência de apresentar menor período embrionário, repetir-se nas demais fases do ciclo biológico de $P$. fluctuosus ou seja, serem mais curtas, como observado para $N$. cervinus (Figura 10), existiria a possibilidade da ocorrência de mais de uma geração por ano para essa espécie, sendo no entanto, necessária tal comprovação com novas pesquisas nessa direção. A ocorrência de mais de uma geração por ano, associada à ampla distribuição de $P$. fluctuosus na área citrícola do estado de São Paulo e no Triângulo Mineiro, MG, além da ampla faixa de desenvolvimento embrionário da espécie (Tabela 1) pode ter facilitado sua adaptação às diferentes regiões. Aliado a tudo isso, às características biológicas e reprodutivas (partenogênese), o desenvolvimento mais rápido podem permitir a essa espécie, destacar-se entre as demais, como praga mais importante para os citros, como foi constatado na pesquisa de distribuição das espécies de curculionídeos dos citros (item 3.3.3).

A viabilidade do período embrionário variou entre 43,4 e $79,6 \%$, com diferentes respostas das espécies estudadas. Enquanto a viabilidade da fase de ovo de $N$. cervinus aumentou nas temperaturas extremas $\left(62,5\right.$ e $79,6 \%$ para 18 e $30^{\circ} \mathrm{C}$, respectivamente), as de $N$. versatilis e de $P$. fluctuosus diminuíram e não diferiram nas temperaturas avaliadas 
(Tabela 2). A viabilidade média da fase de ovo das espécies foi $56,2 \%$ para $P$. fluctuosus, $59,4 \%$ para $N$. versatilis e de $67,8 \%$ para $N$. cervinus. Considerando-se que em laboratório, sob condições que se aproximam das ideais ao desenvolvimento embrionário, as espécies apresentaram uma viabilidade média próxima a $60,0 \%$, possivelmente em condições de campo, com umidade relativa do ar mais baixa e outros fatores abióticos adversos, esses valores estejam muito abaixo de $50 \%$ dos ovos depositados, o que poderia explicar as baixas populações do inseto em alguns anos nas diferentes regiões citrícolas do estado de São Paulo.

Os limiares térmicos inferiores da fase de ovo dos curculionídeos-das-raízes foi de $8,1,8,3$ e $9,9^{\circ} \mathrm{C}$, respectivamente para $N$. versatilis, $N$. cervinus e $P$. fluctuosus; para as

Tabela 1. Duração da fase de ovo de três espécies de curculionídeos-das-raízes dos citros (Coleoptera: Curculionidae) em sete temperaturas. UR de $80 \pm 10 \%$ e fotofase de 14 horas.

\begin{tabular}{|c|c|c|c|}
\hline \multirow{3}{*}{$\begin{array}{c}\begin{array}{c}\text { Temperatura } \\
\left({ }^{\circ} \mathrm{C}\right)\end{array} \\
18\end{array}$} & \multicolumn{3}{|c|}{ Espécies } \\
\hline & Naupactus versatilis & Naupactus cervinus & $\begin{array}{c}\text { Parapantomorus } \\
\text { fluctuosus }\end{array}$ \\
\hline & $\begin{array}{c}38,7 \pm 0,5 a \\
(37-40)^{*}\end{array}$ & $\begin{array}{c}40,4 \pm 0,8 a \\
(38-43)\end{array}$ & $\begin{array}{c}35,0 \pm 0,7 a \\
(33-37)\end{array}$ \\
\hline 20 & $\begin{array}{c}36,2 \pm 0,7 a \\
(34-38)\end{array}$ & $\begin{array}{c}36,5 \pm 0,6 b \\
(34-38)\end{array}$ & $\begin{array}{c}31,2 \pm 0,6 b \\
(28-32)\end{array}$ \\
\hline 22 & $\begin{array}{c}27,4 \pm 1,4 b \\
(24-33)\end{array}$ & $\begin{array}{c}25,8 \pm 0,4 c \\
(25-27)\end{array}$ & $\begin{array}{c}23,8 \pm 0,6 c \\
(22-25)\end{array}$ \\
\hline 25 & $\begin{array}{c}23,5 \pm 0,9 c \\
(22-27)\end{array}$ & $\begin{array}{c}22,4 \pm 0,6 d \\
(20-24)\end{array}$ & $\begin{array}{c}19,7 \pm 1,1 \mathrm{~d} \\
(17-23)\end{array}$ \\
\hline 28 & $\begin{array}{c}20,0 \pm 0,2 c \\
(19-21)\end{array}$ & $\begin{array}{c}19,1 \pm 0,7 \mathrm{e} \\
(16-20)\end{array}$ & $\begin{array}{c}16,4 \pm 0,1 \mathrm{e} \\
(15-17)\end{array}$ \\
\hline 30 & --- & $\begin{array}{c}18,6 \pm 0,3 \mathrm{e} \\
(17-19)\end{array}$ & $\begin{array}{c}13,8 \pm 0,1 \mathrm{e} \\
(13-14)\end{array}$ \\
\hline 32 & --- & -- & $\begin{array}{c}13,8 \pm 0,3 \text { e } \\
(12-14)\end{array}$ \\
\hline
\end{tabular}

* Intervalo de variação. Médias seguidas de letras iguais na coluna, não diferem entre si, pelo teste Tukey, ao nivel de $5 \%$ de probabilidade. 
Tabela 2. Viabilidade da fase de ovo de três espécies de curculionídeos-das-raízes dos citros (Coleoptera: Curculionidae) em sete temperaturas. UR de $80 \pm 10 \%$ e fotofase de 14 horas.

\begin{tabular}{|c|c|c|c|}
\hline \multirow{3}{*}{$\begin{array}{c}\text { Temperatura } \\
\left({ }^{\circ} \mathrm{C}\right)\end{array}$} & \multicolumn{3}{|c|}{ Espécies } \\
\hline & Naupactus versatilis & Naupactus cervinus & $\begin{array}{c}\text { Parapantomorus } \\
\text { fluctuosus }\end{array}$ \\
\hline & \multicolumn{3}{|c|}{ Viabilidade (\%) } \\
\hline 18 & $\begin{array}{c}54,2 \pm 6,8^{*} a \\
(29-68)\end{array}$ & $\begin{array}{c}62,5 \pm 9,0 a b \\
(38-84)\end{array}$ & $\begin{array}{c}73,8 \pm 2,3 a \\
(67-80)\end{array}$ \\
\hline 20 & $\begin{array}{c}62,4 \pm 9,5 a \\
(31-78)\end{array}$ & $\begin{array}{c}51,4 \pm 7,2 b \\
(32-73)\end{array}$ & $\begin{array}{c}59,6 \pm 11,8 a \\
(16-84)\end{array}$ \\
\hline 22 & $\begin{array}{c}62,4 \pm 3,89 a \\
(55-76)\end{array}$ & $\begin{array}{c}63,8 \pm 3,6 a b \\
(58-78)\end{array}$ & $\begin{array}{c}61,0 \pm 8,6 a \\
(41-84)\end{array}$ \\
\hline 25 & $\begin{array}{c}52,0 \pm 5,7 a \\
(46-76)\end{array}$ & $\begin{array}{c}65,4 \pm 4,6 a b \\
(48-73)\end{array}$ & $\begin{array}{c}43,4 \pm 4,4 a \\
(33-55)\end{array}$ \\
\hline 28 & $\begin{array}{c}67,9 \pm 4,6 a \\
(47-72)\end{array}$ & $\begin{array}{c}77,8 \pm 7,3 a b \\
(51-96)\end{array}$ & $\begin{array}{c}59,2 \pm 7,7 a \\
(40-85)\end{array}$ \\
\hline 30 & $\cdots$ & $\begin{array}{c}79,7 \pm 4,6 a \\
(65-96)\end{array}$ & $\begin{array}{c}52,7 \pm 3,7 a \\
(37-58)\end{array}$ \\
\hline 32 & -- & $\cdots$ & $\begin{array}{c}43,4 \pm 5,7 a \\
(27-56)\end{array}$ \\
\hline Média & 59,4 & 67,7 & 56,1 \\
\hline
\end{tabular}

* Intervalo de variação. Médias seguidas de letras iguais na coluna, não diferem entre si, pelo teste Tukey, ao nivel de $5 \%$ de probabilidade.

mesmas espécies, as constantes térmicas foram de 397,7, 385,7 e 294,1 GD, resultados semelhantes aos obtidos para outras espécies de Naupactus (Lakin \& Morse, 1989 e Tarrant \& McCoy, 1989). Por outro lado, P. fluctuosus apresentou constante térmica menor do que as obtidas para as espécies de Naupactus (Tabela 3 e Figura 3). Para $N$. cervinus, Tarrant \& McCoy (1989) observaram constante térmica e temperatura base da fase de ovo como sendo de $267 \mathrm{GD}$, e $10,8^{\circ} \mathrm{C}$; respectivamente; tal valor de Tb está muito próximo ao obtido no presente trabalho, embora tenha havido uma discrepância com relação à constante térmica obtida nas duas pesquisas (Lakin \& Morse, 1989 e Tarrant \& McCoy, 1989). Essa discrepância pode ser explicada pela diferente combinação entre umidade e temperatura utilizada nos dois 
trabalhos, pois Lakin \& Morse (1989) obtiveram, para N. cervinus, constantes térmicas de 251 a 351 GD, dependendo da UR utilizada.

Tabela 3. Temperatura base ( $\mathrm{Tb})$, constante térmica $(K)$ e coeficiente de determinação $\left(R^{2}\right)$ da fase de ovo de espécies de curculionideos-das-raizes dos citros (Coleoptera: Curculionidae). UR de $80 \pm 10 \%$ e fotofase de 14 horas.

\begin{tabular}{lcccc}
\hline \multicolumn{1}{c}{ Espécie } & $\begin{array}{c}\text { Temperatura } \\
\text { Base }\left({ }^{\circ} \mathrm{C}\right)\end{array}$ & $\begin{array}{c}\text { Constante } \\
\text { térmica (GD) }\end{array}$ & $\begin{array}{c}\text { Equação } \\
(1 / D)\end{array}$ & $\begin{array}{c}R^{2 *} \\
(\%)\end{array}$ \\
\hline Naupactus versatilis & 8,11 & 397,68 & $\mathrm{Y}=0,0025 \mathrm{X}-0,0204$ & 98,00 \\
Naupactus cervinus & 8,31 & 385,72 & $\mathrm{Y}=0,0026 \mathrm{X}-0,0215$ & 96,30 \\
Parapantomorus fluctuosus & 9,93 & 294,07 & $\mathrm{Y}=0,0034 \mathrm{X}-0,0338$ & 98,32 \\
\hline
\end{tabular}

*Coeficiente de determinação.

O número de ovos/fêmea das espécies $N$. cervinus e $P$. fluctuosus sem chance de escolha (Exp. B), em papel, folhas e frutos cítricos, não foi significativo para espécies $(F=0,06)$ e para espécies $\times$ substratos $(F=0,24)$. Entretanto, no experimento com chance de escolha (Exp. A), foi significativo para espécies $(F=6,40)$, substratos $(F=70,54)$ e espécies $x$ substratos $(F=6,40)$. Quando não foi dada oportunidade de escolha do local de oviposição, não ocorreu diferença entre as espécies $N$. cervinus e $P$. fluctuosus; entretanto, ambas as espécies ovipositaram igualmente nos frutos e na "sanfona" de papel (Figura 4). Em laboratório, as espécies não ovipositaram nas folhas de citros, comprovando as observações de campo. No teste de livre escolha do substrato de oviposição, tanto $N$. cervinus quanto $P$. fluctuosus preferiram frutos cítricos a papel para oviposição em laboratório; $P$. fluctuosus também não fizeram posturas nas folhas, a despeito de se alimentarem delas (Figura 5). comportamento dos curculionídeos-das-raizes dos citros de ovipositarem sobre papel parafinado, colocado nas gaiolas de criação em laboratório, permitiu o uso da "sanfona" para a coleta de ovos de $N$. cervinus, $N$. versatilis e $P$. fluctuosus. Essa técnica havia sido estudada e adotada por Lakin \& Morse (1989) e por Coats \& McCoy (1990) para N. cervinus; assim, mostrou-se eficiente também para os curculionídeos que ocorrem nos citros e possivelmente aplicável para outros Naupactini. 

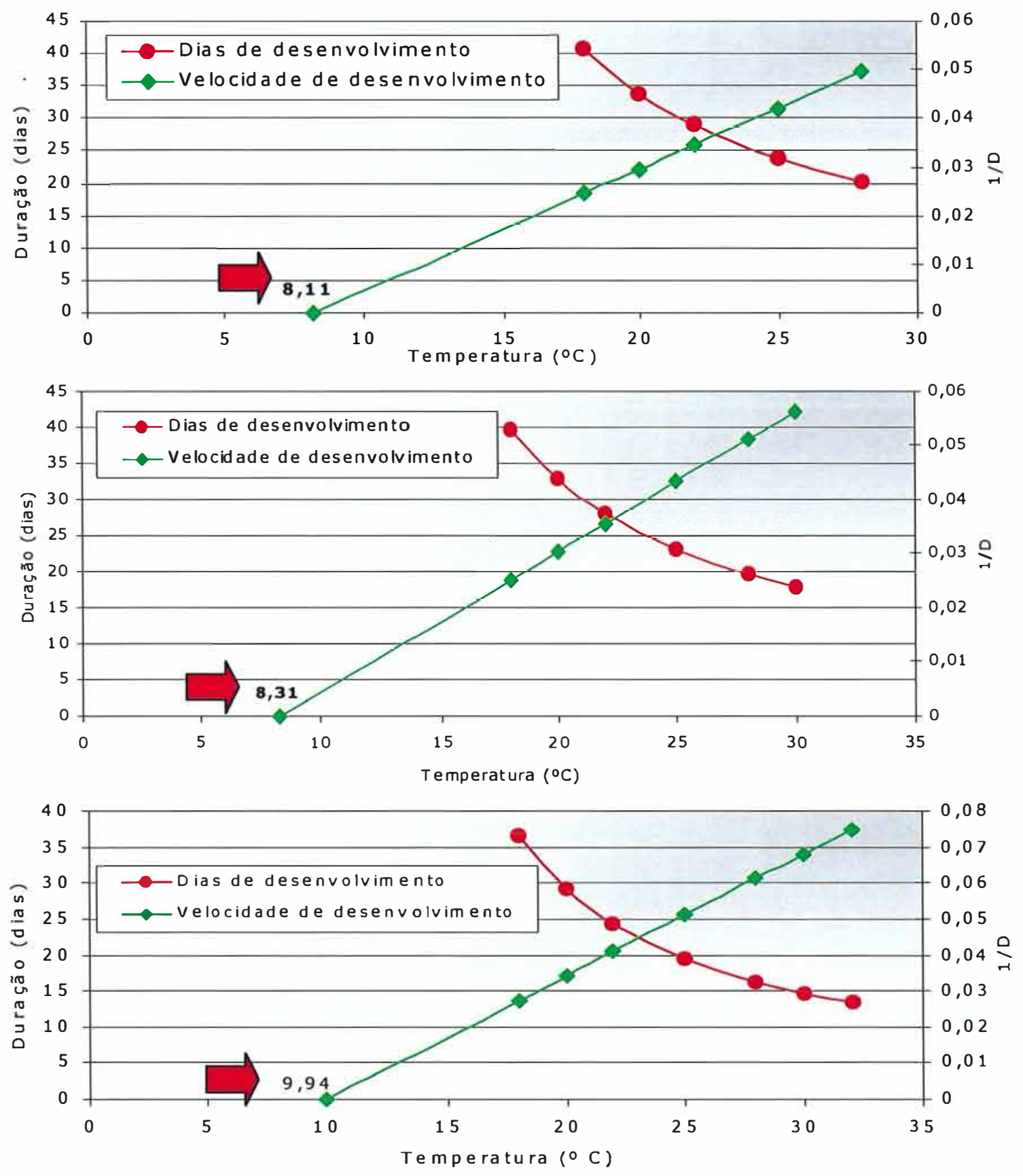

Figura 3. Curva de velocidade de desenvolvimento da fase de ovo de Naupactus versatilis, Naupactus cervinus e Parapantomorus fluctuosus em diferentes temperaturas, com os respectivos limites térmicos inferiores de desenvolvimento (Tb). UR $80 \pm$ $10 \%$ e fotofase de $14 \mathrm{~h}$. 


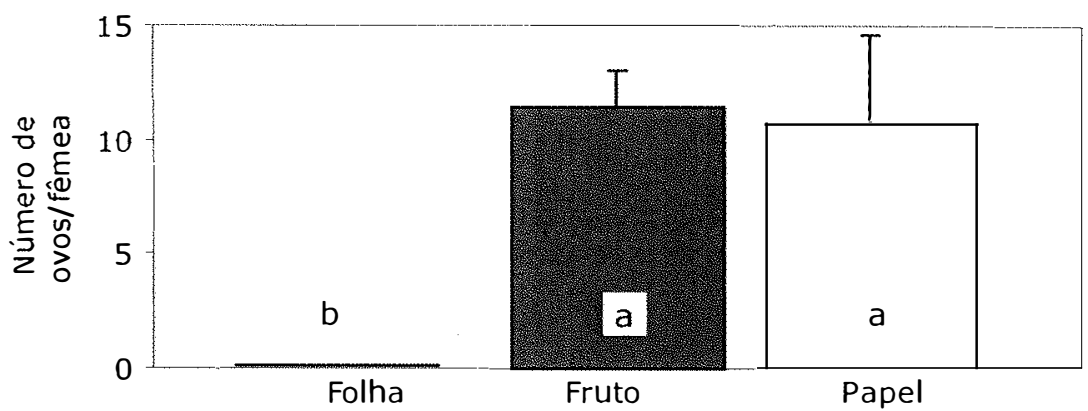

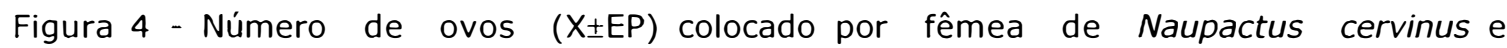
Parapantomorus fluctuosus, sem chance de escolha em três substratos: folha, fruto e papel. Médias seguidas de letras diferentes diferem entre si pelo teste de Tukey, ao nivel de $5 \%$ de probabilidade.

Verificou-se que a cor do fruto usado como substrato (Exp. C) em relação ao número de ovos/fêmea das espécies $N$. cervinus, $N$. versatilis e $P$. fluctuosus, com livre escolha, não foi significativo para substratos $(F=0,18)$ e para espécies $x$ substratos $(F=0,87)$. A escolha do local de oviposição, independe da cor do fruto, devendo estar diretamente relacionada à presença de fendas (Guedes, 2001 obs. pessoal) (Figura 6). Entre as espécies, P. fluctuosus ovipositou mais (15 ovos/fêmea/48h) do que $N$. cervinus e $N$. versatilis (4,9 e 3,4 ovos/fêmea/48h, respectivamente) em laboratório, indicando que a maior capacidade reprodutiva de $P$. fluctuosus, associada a sua distribuição no estado de São Paulo (4.3.1), colocam a espécie como uma das mais importantes entre os curculionídeos dos citros.

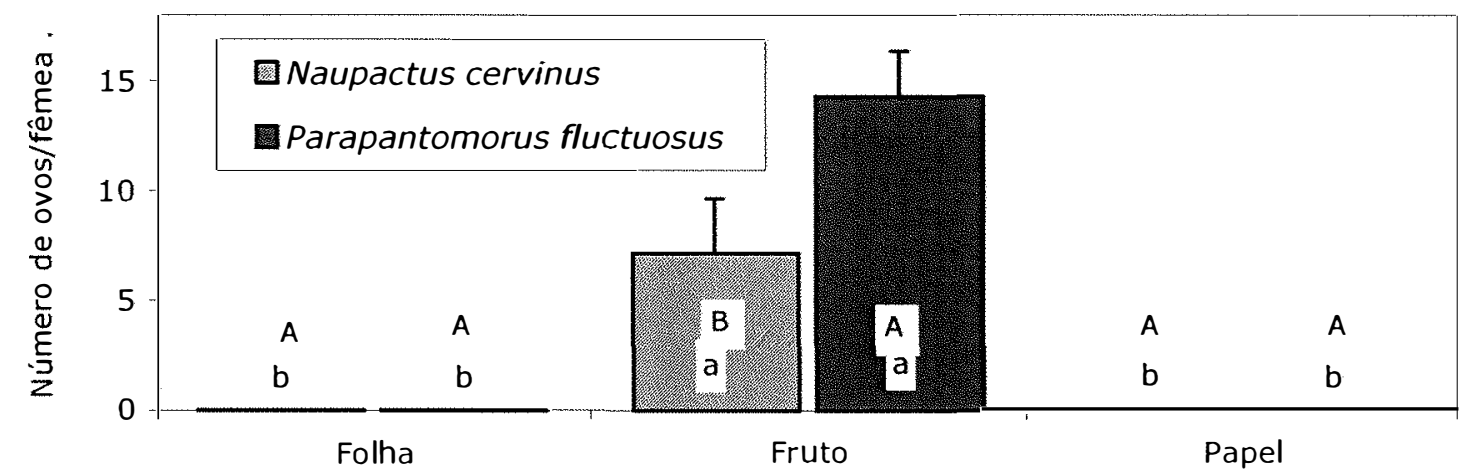

Figura 5 - Número de ovos $(X \pm E P$ ) colocado por fêmea de $N$. cervinus e $P$. fluctuosus em experimento com livre escolha em três substratos: folha, fruto e papel. Médias seguidas por letras minúsculas diferentes (espécie) e maiúsculas (substrato) diferem entre si pelo teste de Tukey a $5 \%$ de probabilidade. 


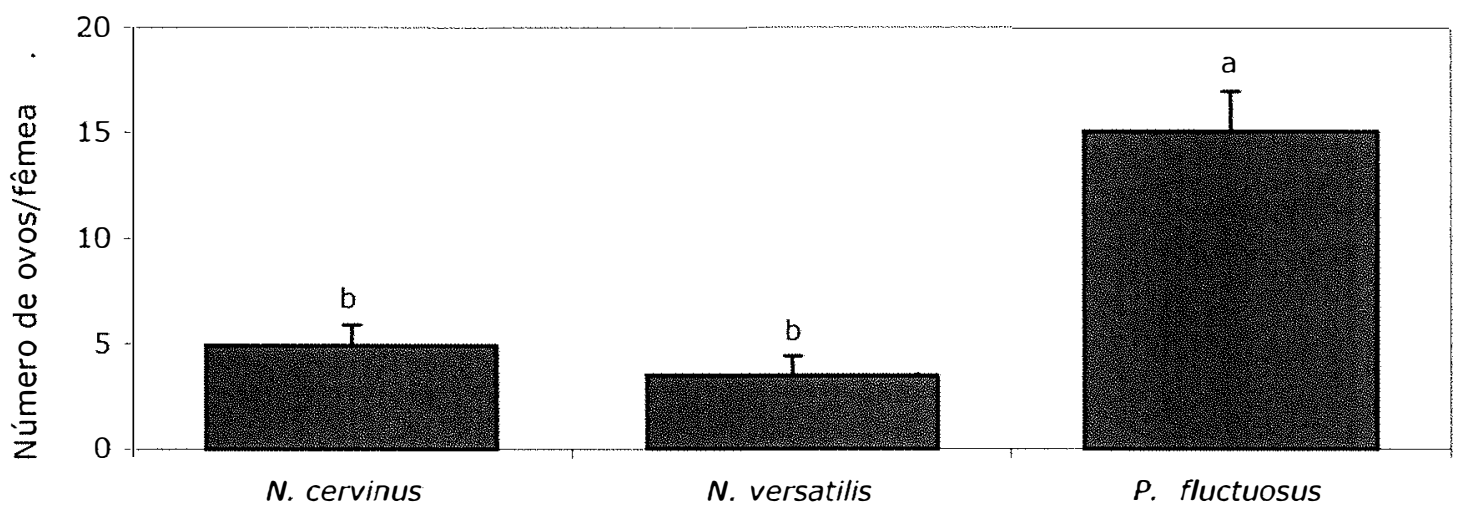

Figura 6 - Número de ovos (X士EP) colocados por fêmea de Naupactus cervinus, N. versatilis e Parapantomorus fluctuosus em experimento com livre escolha de frutos de diferentes cores. Médias seguidas por letras iguais não diferem entre si pelo teste de Tukey a $5 \%$.

Nos experimentos visando avaliar o efeito da distância do cálice à superfície do fruto na oviposição dos curculionídeos-das-raízes dos citros, tanto no teste sem chance de escolha como no de livre escolha, as diferenças foram significativas para espécie e para distância. No experimento sem livre escolha, embora sem apresentar diferença quanto ao número de ovos por fêmea, $N$. cervinus não realizou e $N$. versatilis raramente colocou ovos em frutos com o pedúnculo afastado. As maiores médias de ovos/fêmea, foram observadas para pedúnculo aderido e intermediário. $P$. fluctuosus ovipositou preferencialmente em frutos com distância intermediária do cálice à superfície do fruto, embora a espécie também tenha feito posturas em frutos com cálice aderido e afastado (Figura 7). No experimento de livre escolha, as respostas das espécies foram semelhantes ao teste sem chance de escolha, porém somente P. fluctuosus fez postura em frutos com o cálice afastado da casca do fruto, caracterizando habilidade da espécie para ovipositar em fendas de diferentes tamanhos (Figura 8). A alteração da distância entre o cálice e a superfície do fruto envolve dois fatores principais. A característica da variedade em apresentar um cálice grande e aderido, torna a fenda adequada à oviposição de alguns Naupactini que ocorrem em citros. Embora a média do número de ovos/fêmea não tenha mostrado diferença entre alturas/distâncias, provavelmente em função da grande variação das mesmas, foi clara a preferência de $N$. 
cervinus, $N$. versatilis e $P$. fluctuosus em ovipositar em fendas mais estreitas, ou seja, quando o cálice estava mais próximo à casca do fruto. Embora os Naupactini prefiram fendas estreitas (cálice aderido), essas devem ser amplas, o suficiente para permitir que a fêmea introduza o ovipositor distendido, e não serem demasiadamente afastadas a ponto de exporem a postura à dessecação e aos inimigos naturais.

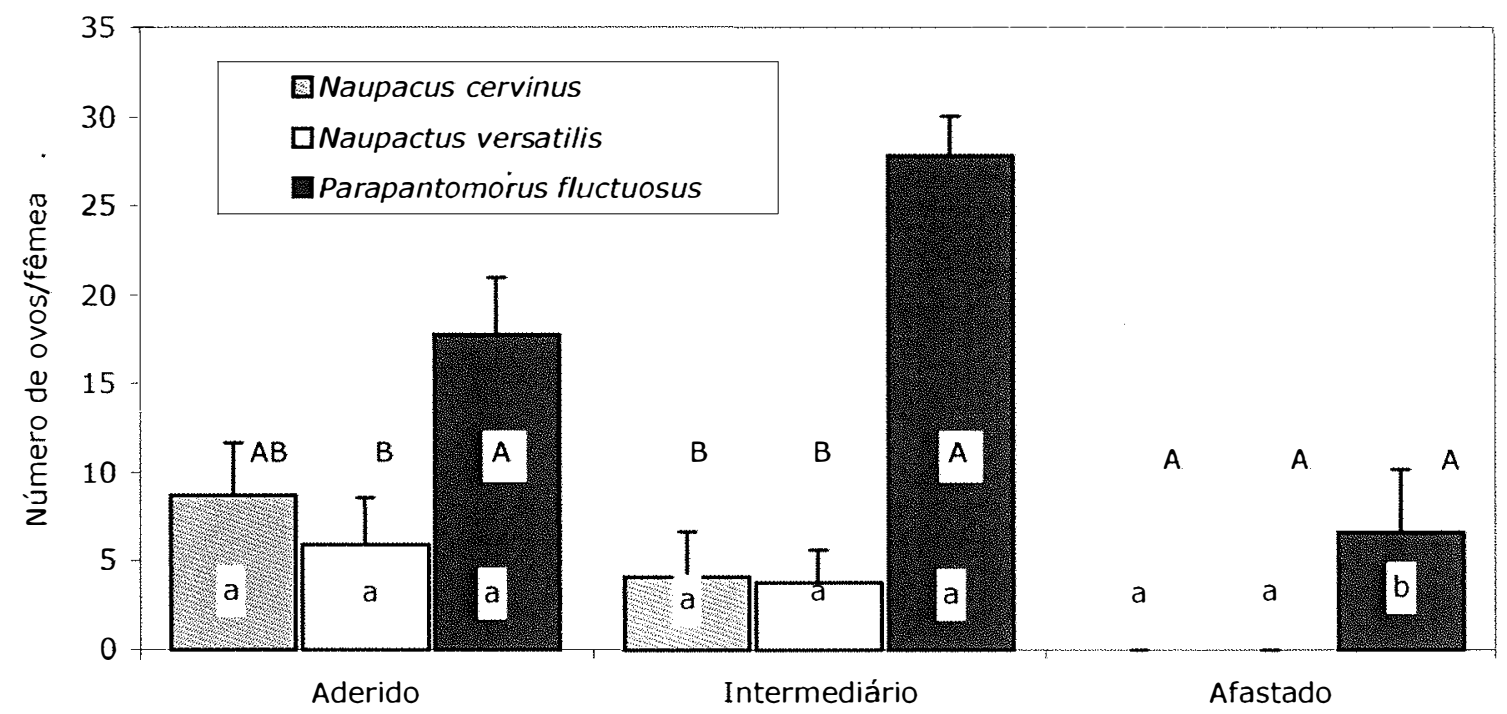

Figura 7 - Número de ovos (X士EP) colocado por fêmea de $N$. cervinus, $N$. versatilis e $P$. fluctuosus em experimento sem chance de escolha com três distâncias de cálice: aderido, intermediário e afastado. Médias seguidas por letras minúsculas diferentes (espécie) e maiúsculas diferentes (distância) diferem entre si pelo teste de Tukey a 5\% de probabilidade.

Quanto ao tipo de substrato, $N$. versatilis, Naupactus tarsalis Boheman e Teratopactus nodicollis (Boheman) preferiram ovipositar no solo e em resíduos vegetais (Figura 9), quando comparados aos frutos, que são estruturas preferidas pelas espécies de porte pequeno, como $N$. cervinus e $P$. fluctuosus. Dentre as espécies que ovipositaram no solo, $\boldsymbol{N}$. versatilis e $\boldsymbol{N}$. tarsalis depositam massas de ovos envoltas por substância adesiva e T. nodicollis coloca seus ovos isoladamente e sem substância adesiva. A ausência de substância adesiva limita a oviposição, pois os ovos não aderem ao substrato e possivelmente por isso não ocorram na parte aérea da planta. 


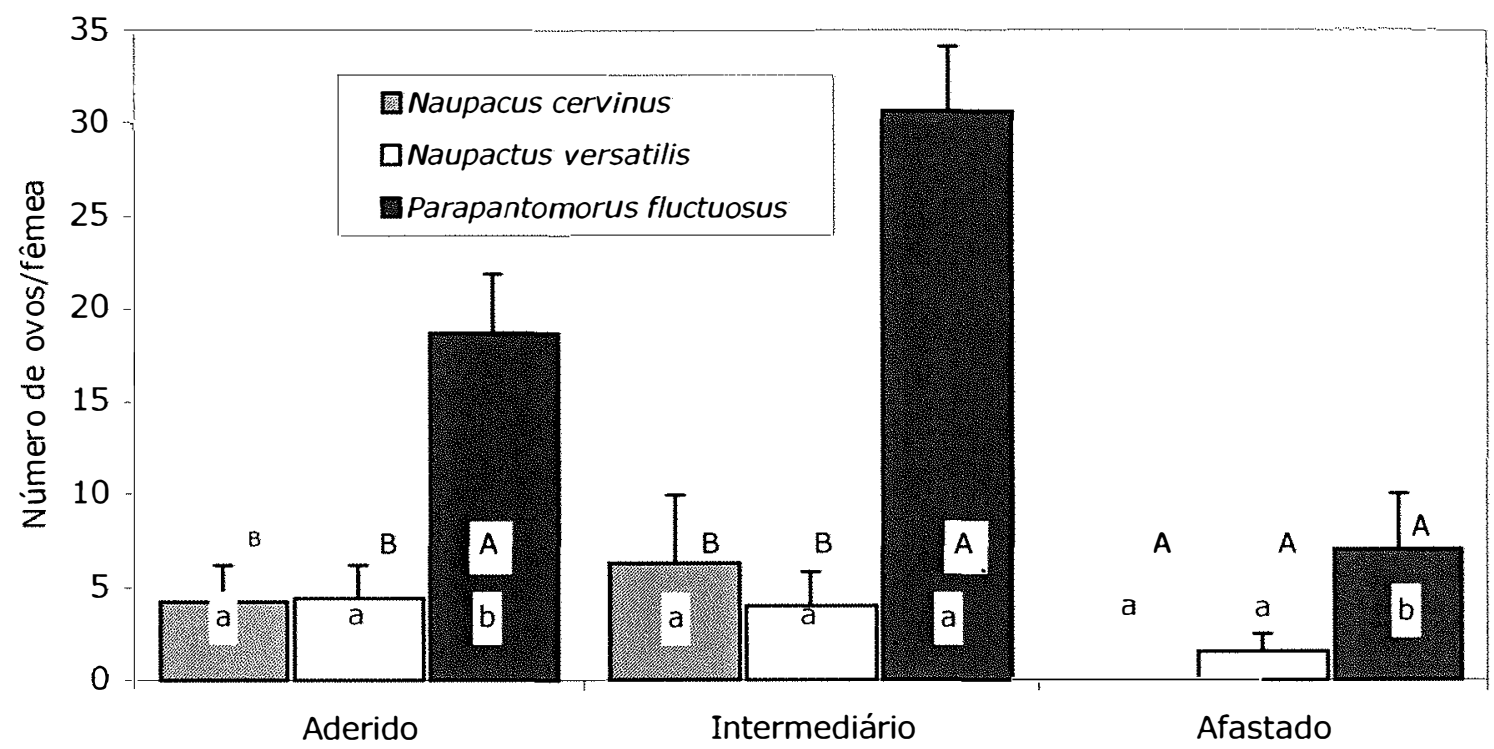

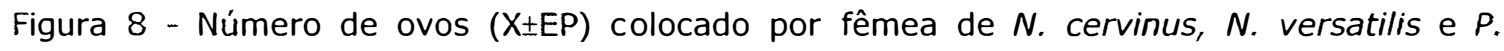
fluctuosus em experimento com livre escolha em três distâncias de cálice: aderido, intermediário e afastado. Médias seguidas por letras minúsculas diferentes (espécie) e maiúsculas diferentes (distância) diferem entre si pelo teste de Tukey a $5 \%$ de probabilidade.

Segundo Loiácono \& Malvardi (1994) e Marvaldi (1999) algumas espécies de Naupactini colocam os ovos no solo ou na base da planta, porém devido às dificuldades metodológicas de se amostrar o solo, sua ocorrência nesse local e características, raramente foram estudadas. A ocorrência de posturas no solo deve estar relacionada à falta na planta, de locais adequados à postura, como fendas; um outro fator que determinaria a oviposição no solo possivelmente esteja ligado ao tamanho das espécies, pois espécies grandes não dificilmente conseguiriam ovipositar nos frutos, pelos motivos expostos anteriormente.

Desse modo, a oviposição na parte aérea da planta cítrica deve estar ligada não somente ao tipo de ovipositor (Lanteri et al, 1994), como também ao porte do inseto, uma vez que as espécies maiores, como $\boldsymbol{N}$. tarsalis, preferiram fazer suas postura no solo e nos resíduos, mesmo apresentando ovipositor pouco esclerosado (3.3.2), embora Coats \& McCoy (1990) tenham observado que $N$. cervinus também oviposita no solo, junto à planta. 


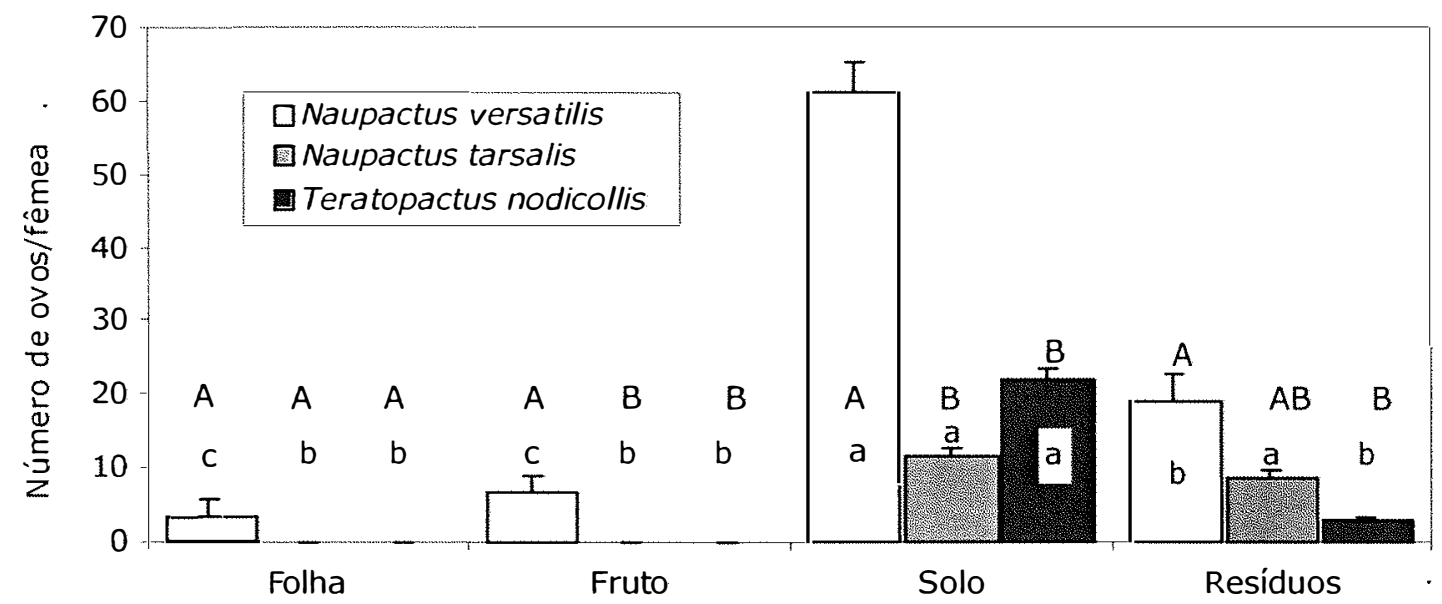

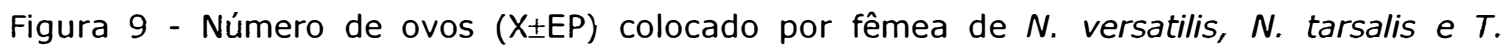
nodicollis com livre escolha em quatro tipos de substratos: folha, fruto, solo e resíduo. Médias seguidas por letras minúsculas diferentes (espécie) e maiúsculas diferentes (substrato) diferem entre si pelo teste de Tukey a $5 \%$ de probabilidade.

\subsubsection{Período larva-pupa}

Das plantas de limão cravo, infestadas com larvas recém eclodidas de $N$. cervinus, emergiram 64 adultos; tal emergência ocorreu a partir dos 110 dias após a infestação das plantas, durante 98 dias, até os 208 DAI. A duração média do período larva-pupa foi de 143 dias em limão cravo. Emergiram 45 adultos de $N$. cervinus das plantas de Citrumelo Swingle, com início aos 131 DAI, durante 121 dias, até os 252 dias após a infestação, com um período médio larva-pupa foi de 200 dias (Figura 10). Em limão cravo, o período de emergência de $N$. cervinus foi menor do que em Citrumelo Swingle, permitindo inferir que as raízes de limão cravo são mais adequadas ao desenvolvimento desses curculionídeos-dasraízes dos citros. Apesar da infestação ter sido feita com larvas oriundas da mesma população de fêmeas, de mesma idade e as plantas mantidas no telado, sob as mesmas condições climáticas, os adultos de $N$. cervinus emergiram durante longos períodos em ambos os porta-enxertos utilizados para o desenvolvimento larva-pupa. Esses resultados 
podem explicar, em parte, a emergência escalonada dos adultos dessa espécie, observada a partir dos meses mais quentes e chuvosos no estado de São Paulo (item 5.3.4).

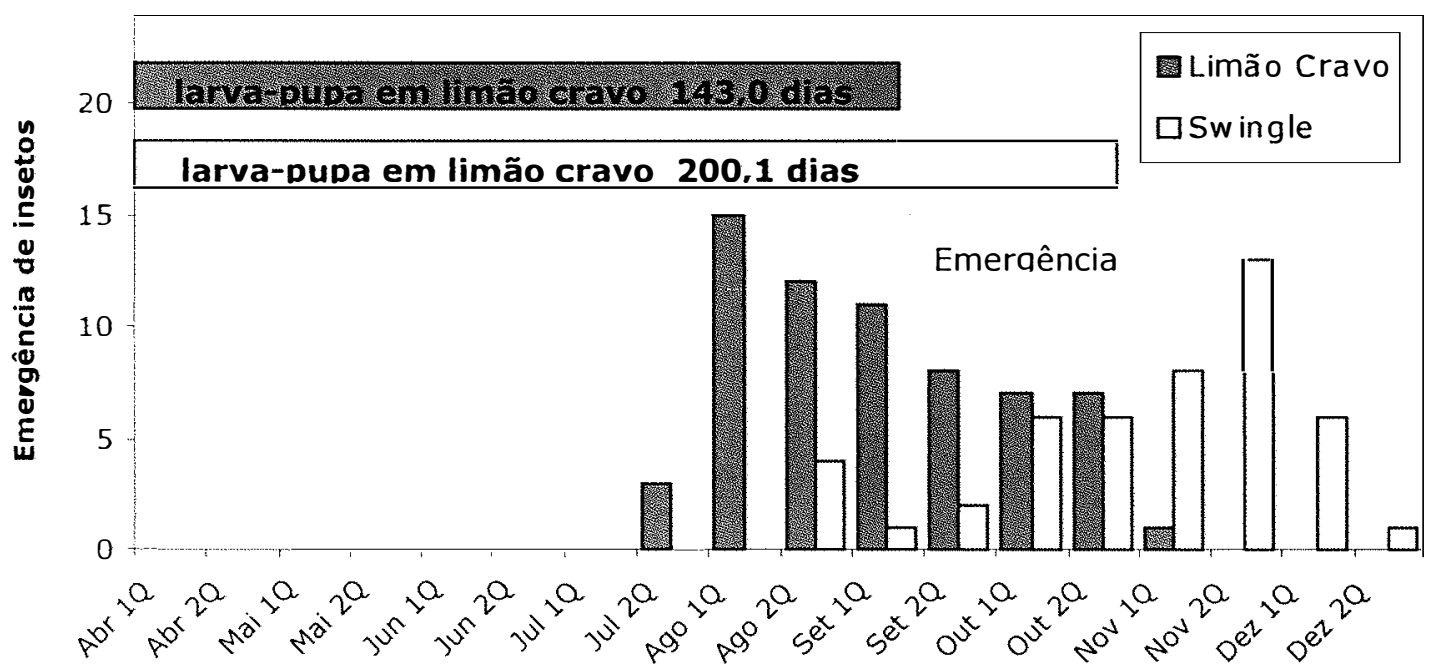

Figura 10 - Emergência de adultos por quinzena e duração média do período larva-pupa de Naupactus cervinus criados em porta-enxertos, em telado. Piracicaba, SP, no período de 04/2001 a 12/2001. (1Q = primeira quinzena).

Das plantas de limão cravo infestadas com as larvas recém eclodidas de $N$. versatilis emergiram 65 adultos, com inicio 147 dias até 213 dias após a infestação das plantas, emergindo durante aproximadamente 170 dias. Nesse período ocorreram dois picos de emergência, como foi observado por Ripa (1992), para Naupactus xantographus (Germar), em videira, no Chile. O Autor caracterizou esse comportamento como um recurso da espécie para aumentar a possibilidade de encontrar condições climáticas favoráveis na superfície (Figura 11).

A duração média do período larva-pupa de N. versatilis foi de 229 dias (Figura 11). Comparando o desenvolvimento das duas espécies em limão cravo, tanto a duração média do período larva-pupa, quanto o tempo de emergência dos adultos foi maior para $N$. versatilis do que para $N$. cervinus, demonstrando que a primeira espécie apresenta ciclo biológico mais longo. A emergência escalonada da população permitiria aos adultos encontrarem diferentes variações climáticas na superfície, aumentando as chances de sobrevivência da espécie. 


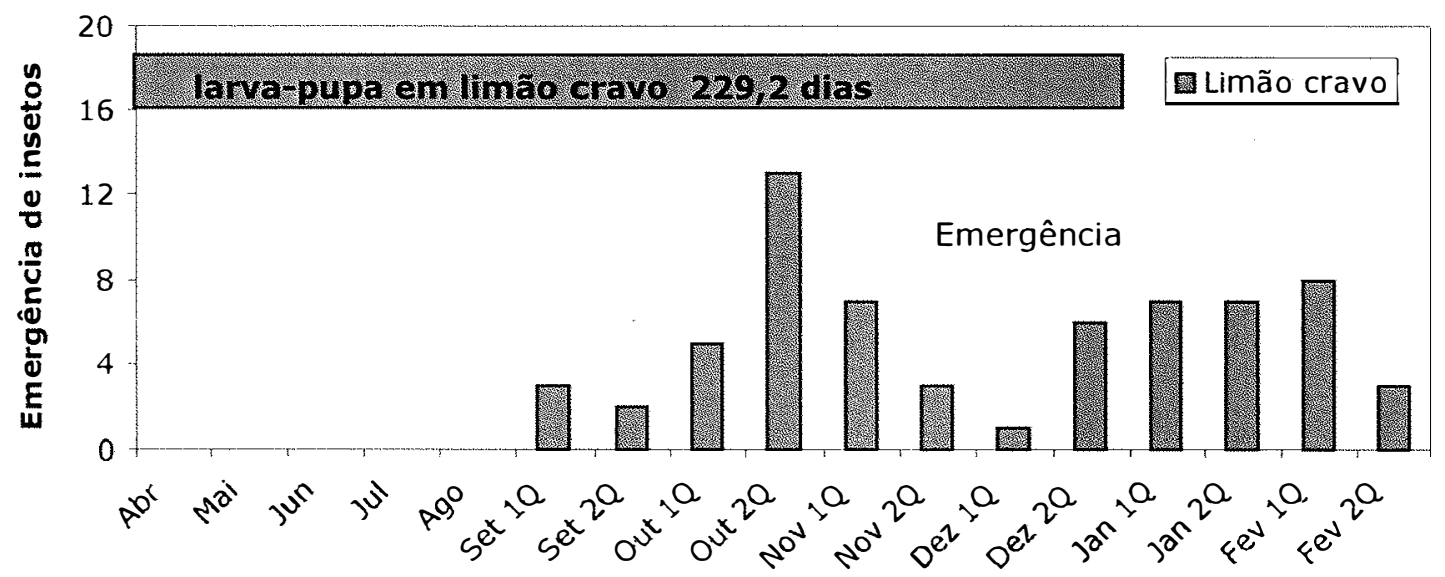

Figura 11 - Emergência de adultos por quinzena e duração média do período larva-pupa de Naupactus versatilis criados em plantas de limão cravo, em telado. Piracicaba, SP, no período de 04/2001 a 02/2002. (1Q = primeira quinzena).

Considerando-se que o limão cravo é o porta-enxerto predominante da citricultura paulista, esse fator pode ter favorecido o crescimento populacional dos curculionídeos-dasraízes no estado de São Paulo. Uma vez comprovado que o limão cravo favorece o desenvolvimento de $N$. cervinus e/ou de outras espécies de Naupactini, a escolha do porta enxerto poderá ser uma técnica cultural a ser adotada visando reduzir a importância desse grupo de insetos. A morte súbita, doença recém constatada no estado de São Paulo e que seria transmitida por afídeos, poderá levar à substituição dos porta-enxertos dos citros, especialmente do limão cravo que é predominante no estado. Esta substituição poderá levar à diminuição da ocorrência dos curculionídeos, caso seja confirmada a hipótese, levantada na presente pesquisa.

Nas avaliações do desenvolvimento larval foram encontradas 35 pupas de $N$. cervinus, em limão cravo, durante um período de 97 dias, permitindo estimar uma fase larval média de 135 dias, que subtraído do período larva-pupa de 143 dias do período larva-pupa, resulta em uma fase pupal muito curta, com sete dias aproximadamente. Como as pupas avaliadas não foram as que originaram os adultos do estudo do período larva-pupa de $N$. cervinus, em limão cravo, possivelmente, o período pupal esteja subestimado, uma vez que Edwards et al. (1993) observaram fase pupal de mais de 40 dias para a espécie. Foram 
coletadas 22 pupas de $\boldsymbol{N}$. cervinus em Citrumelo Swingle durante 136 dias, com um período larval médio de 182 dias, que subtraído dos 200 dias observados para o período larva-pupa, possibilitam inferir uma duração 18 dias para a fase pupal da espécie. Foram observadas 36 pupas de $N$. versatilis durante um período de 167 dias, resultando em uma fase larval média de 181 dias, que subtraída dos 229 dias do período larva-pupa, permite uma estimativa de 48 dias para a fase pupal. Considerando-se somente a duração estimada das fases de pupa de $N$. versatilis e de $N$. cervinus em Citrumelo Swingle, chega-se a uma média de 33 dias, valor próximo ao normalmente referido para os Naupactini sulamericanos (Lanteri et al., 1994; Ripa, 1992) e diferente daquele observado para Artipus floridanus Horn,, praga dos citros nos EUA que apresenta um período pupal de 14 a 20 dias (McCoy et al., 1985) demonstrando portanto, a grande variação da fase pupal para esse grupo.

Foram coletadas 273 larvas de $N$. cervinus em limão cravo e 229 larvas de $N$. cervinus das plantas de Citrumelo Swingle, além de 212 larvas de $\boldsymbol{N}$. versatilis do limão cravo para medição da largura da cápsula cefálica. Para N. cervinus, nos dois porta-enxertos avaliados, as larvas apresentaram cinco ínstares bem definidos; no entanto, para N. versatilis foram testadas as hipóteses de cinco, seis e sete ínstares, optando-se pela hipótese de cinco ínstares, em função do maior valor para a Constante de Dyar (Tabela 4) e a maior distância entre os valores das larguras de cápsula cefálica observada nos últimos ínstares. Para a maioria dos insetos estudados, a duração dos instares e os intervalos de valores ficam maiores a medida que os insetos crescem (Parra, 2002 - inf. pessoal). Nesse sentido, Gough \& Brown (1991) observaram que a distância entre os "picos" de freqüência de largura das cápsulas cefálicas de Naupactus leucoloma Boheman também aumentaram com o desenvolvimento larval do inseto.

Embora tenha ocorrido uma grande distribuição das medidas da largura da cápsula cefálica de $N$. cervinus e $N$. versatilis, criados em limão cravo (Figura 12a e 12c), foi possível discriminar algumas concentrações de larguras, permitindo afirmar que existe grande possibilidade de terem ocorrido cinco ínstares larvais. De forma semelhante, as larvas de $N$. cervinus, criadas em Citrumelo Swingle apresentaram larguras e distribuição das 
concentrações de larguras de cápsula cefálica similares as dos curculionídeos criados em limão cravo (Figura 12b), de modo que é possível afirmar que o alimento não interferiu no números de ínstares das espécies de Naupactus avaliadas, embora seja conhecido que o número de ínstares pode variar com a temperatura, alimento, forma de criação e fatores genéticos (Parra \& Haddad, 1989).

Tabela 4. Constante de Dyar e coeficiente de determinação para as hipóteses do número de instares para duas espécies de curculionídeos-das-raízes criados em dois portaenxertos de citros. Piracicaba, SP de 04/2001 a 02/2002.

\begin{tabular}{lccccc}
\hline Espécie & $\begin{array}{c}\text { Número de } \\
\text { instares }\end{array}$ & $\begin{array}{c}\text { Constante de } \\
\text { Dyar (K) }\end{array}$ & $\mathrm{R}^{2^{*}}$ & $\begin{array}{c}\text { Número } \\
\text { de larvas }\end{array}$ & Porta-enxerto \\
\hline Naupactus cervinus & 5 & 1,41 & 1,00 & 273 & Limão cravo \\
Naupactus cervinus & 5 & 1,39 & 1,00 & 273 & $\begin{array}{c}\text { Citrumelo } \\
\text { Swingle }\end{array}$ \\
Naupactus versatilis & 5 & 1,50 & 0,99 & 208 & Limão cravo \\
Naupactus versatilis & 6 & 1,36 & 0,99 & 208 & Limão cravo \\
Naupactus versatilis & 7 & 1,27 & 0,99 & 208 & Limão cravo \\
\hline * Coeficiente de determinação. & & & & &
\end{tabular}



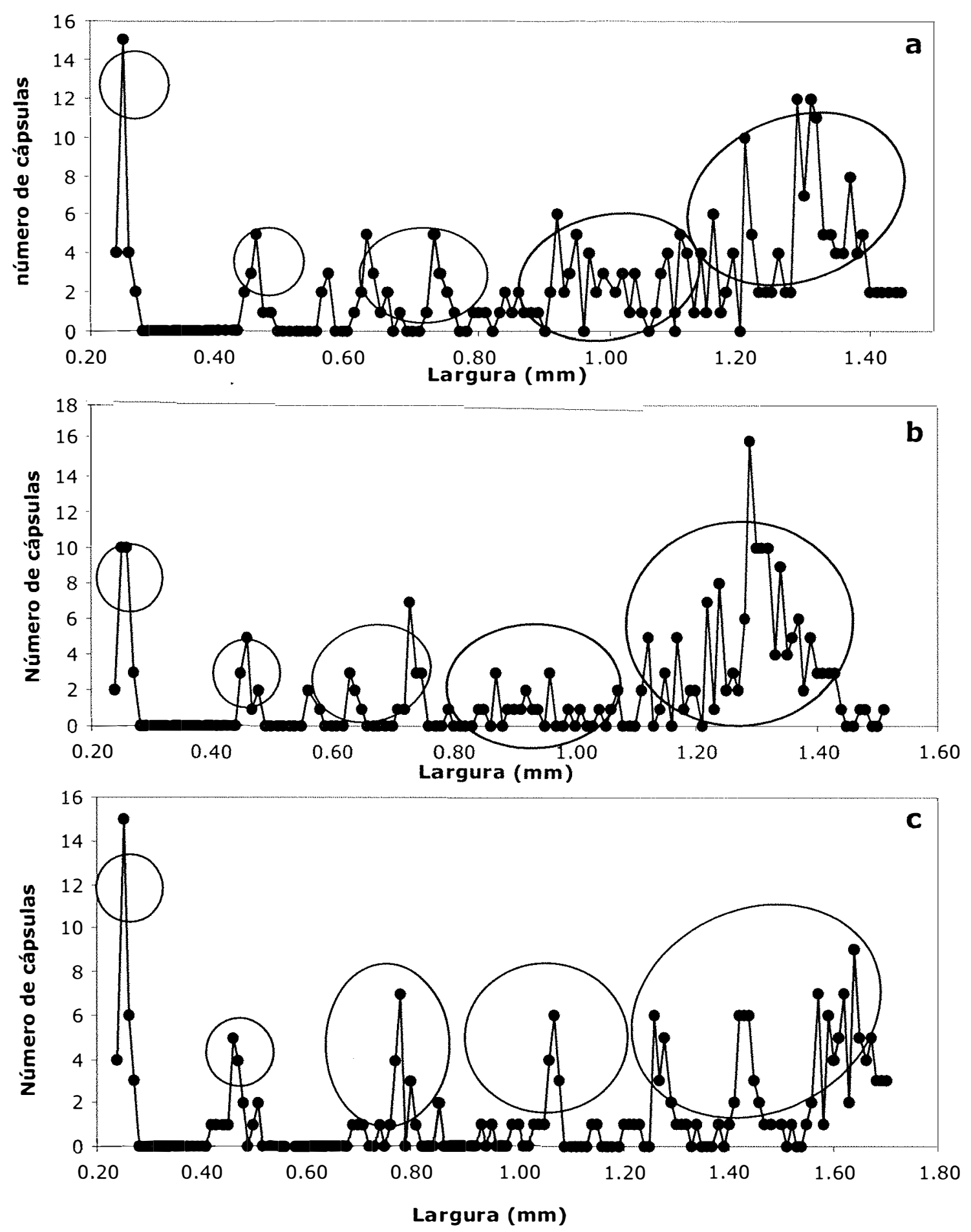

Figura 12 - Curva de distribuição de freqüência de largura de cápsulas cefálicas de a) Naupactus cervinus criado em limão cravo, b) $N$. cervinus em Citrumelo Swingle e c) $N$. versatilis em limão cravo, em telado. Piracicaba-SP, de 04/2001 a $12 / 2001$. 


\subsubsection{Fase adulta}

A longevidade dos adultos dos curculinídeos-das-raízes dos citros e o tempo de alimentação foi diferente para as duas espécies estudadas, sendo que $N$. versatilis viveu 30,9 dias, sendo, portanto, mais longevo do que $N$. cervinus, que apresentou uma longevidade de 25,2 dias. O tempo de alimentação foi também maior para $N$. versatilis do que para $N$. cervinus, com tendência semelhante à longevidade, ou seja, em média dois dias a menos. Como na fase adulta, os insetos não se alimentaram, logo após a emergência e no período que antecedeu a sua morte, o tempo de alimentação aproximou-se da longevidade dos mesmos (Figura 13). Segundo Lanteri et al. (1994), o início da alimentação dos Naupactini depende da perda de um apêndice presente na parte terminal da mandíbula. A perda de tal apêndice é fundamental para o inseto se alimentar e não morrer de inanição. Ottens \& Todd (1979) estudaram o efeito do alimento utilizado pelos adultos de Naupactus peregrinus (Buchanan) sobre a sua longevidade, observando que essa variou de 58 dias, quando se alimentaram de sorgo e de 170 dias, quando o alimento foi abóbora, demonstrando variações para a mesma espécie em função do alimento ingerido. Outras espécies de Naupactus são

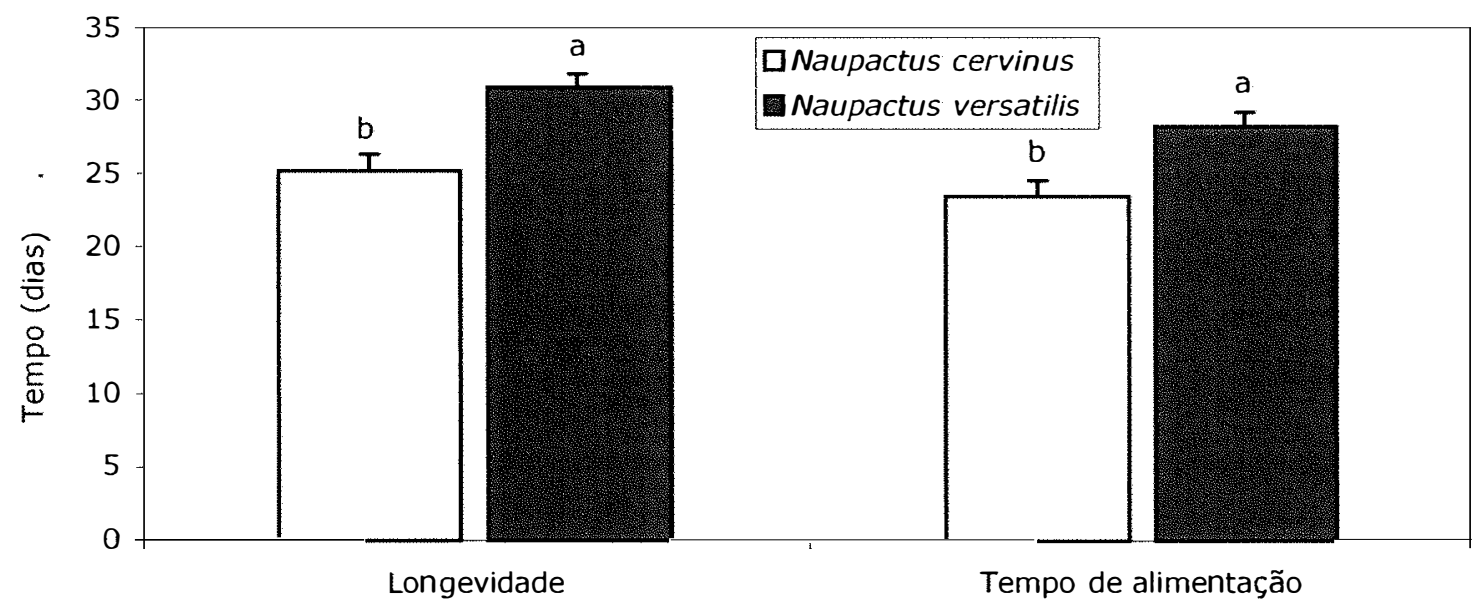

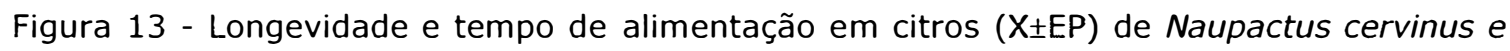
$N$. versatilis. Temperatura $25 \pm 1^{\circ} \mathrm{C}$, UR $80 \pm 10 \%$ e fotofase de $14 \mathrm{~h}$. Médias seguidas por letras desiguais diferem entre si, pelo teste Tukey ao nível de $5 \%$ de probabilidade. 
mais longevas do que $N$. cervinus e $N$. versatilis, como $N$. xantographus, que segundo Gonzalez (1982), vive de um a três meses, em condições de campo e até oito meses, em laboratório.

O período de pré-oviposição de $N$. cervinus foi mais longo $(11,6$ dias $)$ do que o de $N$. versatilis $(6,7$ dias $)$. Com o período de oviposição ocorreu o oposto, pois $N$. versatilis ovipositou durante 17,8 dias e $N$. cervinus somente durante 9,7 dias (Figura 14); independentemente da espécie, o somatório desses dois períodos pode ter aplicação prática no manejo das espécies. Isoladamente, o período de pré-oviposição é o espaço de tempo no qual é possível intervir para impedir a oviposição. Esse período, somado ao período embrionário, é o tempo, em dias, disponível para intervenções antes da eclosão das larvas, sendo a sua duração um importante fator para a ação dos inimigos naturais e para a adoção de práticas de manejo dos curculionídeos-das-raízes dos citros, em condições de campo. Nesse período, que ultrapassa 20 dias para $N$. cervinus e para $N$. versatilis, além da ação dos inimigos naturais, dentre as práticas passíveis de adoção, a pulverização com produtos esterilizantes de fêmeas ou com ovicidas poderia reduzir a infestação das raizes das plantas cítricas com larvas recém eclodidas. Assim, com a determinação da época de emergência das diferentes espécies e forem aplicados os conhecimentos referentes à biologia de tais espécies

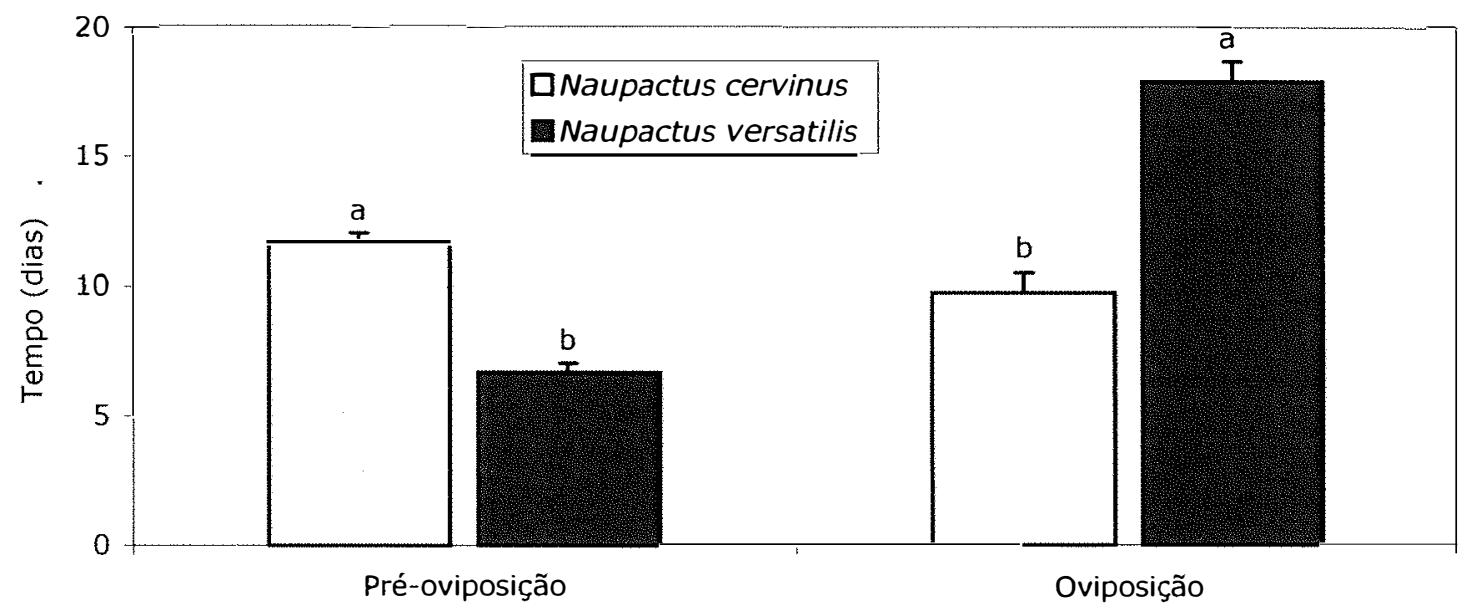

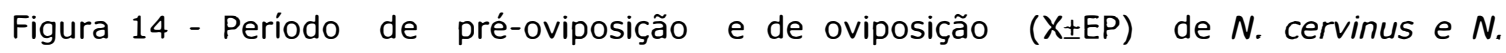
versatilis. Temperatura $25 \pm 1^{\circ} \mathrm{C}$, UR $80 \pm 10 \%$ e fotofase de $14 \mathrm{~h}$. Médias seguidas por letras desiguais diferem entre si, pelo teste Tukey ao nivel de $5 \%$ de probabilidade. 
será possivel racionalizar o controle desses curculionídeos. O período de pré- oviposição de $A$. floridanus, praga dos citros na Califórnia (EUA), varia de 11 a 27 dias, sendo maior para fêmeas virgens (McCoy et al., 1985).

A metodologia utilizada no trabalho não permitiu determinar o tempo de permanência dos curculionídeos-das-raízes no solo, após a sua emergência. Entretanto, Gonzalez (1982) e Ripa (1992) fazem referência a esse comportamento de N. xantographus, cujos adultos permaneceriam no solo de 25 a mais de 100 dias, antes de saírem à superfície. Possivelmente, esse período, esteja relacionado a diversos fatores, incluindo estrutura, textura, compactação e umidade do solo, profundidade de pupação e da ocorrência de condições climáticas adequadas na superfície (observações de campo indicam que os curculionídeos-das-raízes dos citros aparecem na superfície do solo após os primeiros períodos de chuvas, indicando uma estreita relação com a umidade do solo). A não determinação desse período de permanência no solo, na presente pesquisa, poderia resultar em períodos de pré-oviposição e de longevidade subestimados. De forma análoga, poderia explicar a menor longevidade observada para os curculionídeos estudados na presente pesquisa, comparados a de outras espécies, como N. xantographus (Gonzalez, 1982; Ripa, 1992) e N. peregrinus (Ottens \& Todd, 1979).

Em laboratório, as fêmeas de $N$. versatilis realizaram, em média, 6,6 posturas totalizando 214,6 ovos, enquanto que as fêmeas de $N$. cervinus fizeram 4,2 posturas, num total de 120,9 ovos, número bem inferior à primeira espécie, o que poderia parcialmente ser explicado pelo maior volume corporal de $N$. versatilis. McCoy (1994) afirmou que $N$. cervinus coloca entre 70 e 100 ovos, valor pouco aquém daquele observado no presente trabalho (Figura 15). Para $N$. peregrinus tem sido registrada uma grande variação no número de ovos dependendo do alimento utilizado na fase adulta (Ottens \& Todd, 1979). Comparadas a outras espécies de Naupactus, $N$. versatilis e $N$. cervinus oriundas dos citros colocam um número menor de ovos, pois segundo May (1977), N. leucoloma alimentado com folhas de amendoim, oviposita mais de 1600 ovos e $N$. xantographus, em videira, tem uma capacidade de postura superior a 1000 ovos (Ripa, 1983). 

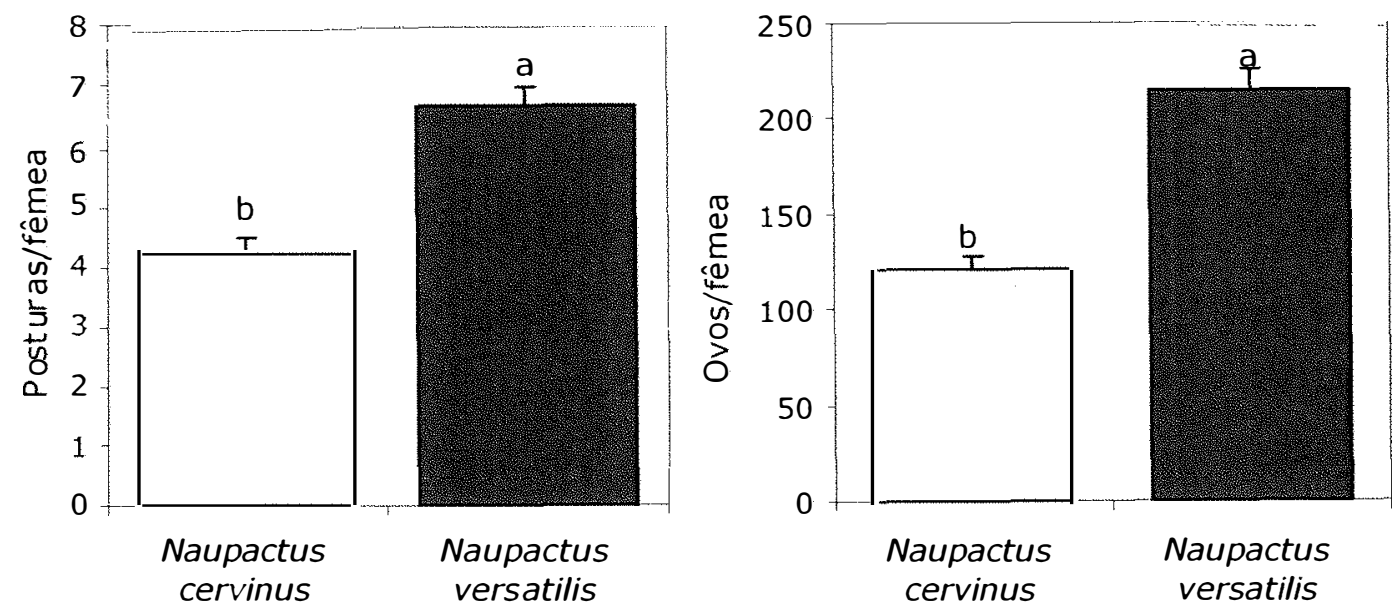

Figura 15 - Número de posturas e número de ovos/fêmea $(X \pm E P)$ de $N$. cervinus e $N$. versatilis. Temperatura $25 \pm 1^{\circ} \mathrm{C}$, UR $80 \pm 10 \%$ e fotofase de $14 \mathrm{~h}$. Médias seguidas por letras desiguais diferem entre si, pelo teste Tukey ao nivel de $5 \%$ de probabilidade.

O consumo foliar diário dos curculionídeos-das-raízes dos citros variou com a espécie estudada e possivelmente esteja associado ao tamanho do inseto, pois $N$. versatilis consumiu $0,80 \mathrm{~cm}^{2} /$ dia enquanto que $N$. cervinus consumiu $0,58 \mathrm{~cm}^{2} /$ dia, sendo essa espécie a de menor tamanho corporal. O consumo total seguiu o mesmo padrão, com $N$. versatilis totalizando mais de $31,0 \mathrm{~cm}^{2}$ de área foliar destruída, enquanto que $N$. cervinus não passou de $15,0 \mathrm{~cm}^{2}$ de folhagem consumida, valores esses resultantes tanto do menor consumo diário de $N$. cervinus como da sua menor longevidade (Figura 16). O consumo das folhas dos citros pelos Naupactini tem sido pouco estudado, possivelmente pelo fato dos danos mais importantes serem causados pelas larvas às raízes. O consumo entre 15,0 e $30,0 \mathrm{~cm}^{2}$ pode representar pouco para a planta cítrica, exceto no caso de plantas jovens por apresentarem reduzida área foliar ou em populações muito elevadas dos Naupactini dos citros. Em pomares adultos, as plantas replantadas, portanto também jovens, sentem mais o desfolhamento causado pelos curculionídeos, em virtude da sua menor área foliar levando a uma maior perda de água e redução da atividade fotossintetizadora (Sylvertsen \& McCoy, 1985). 

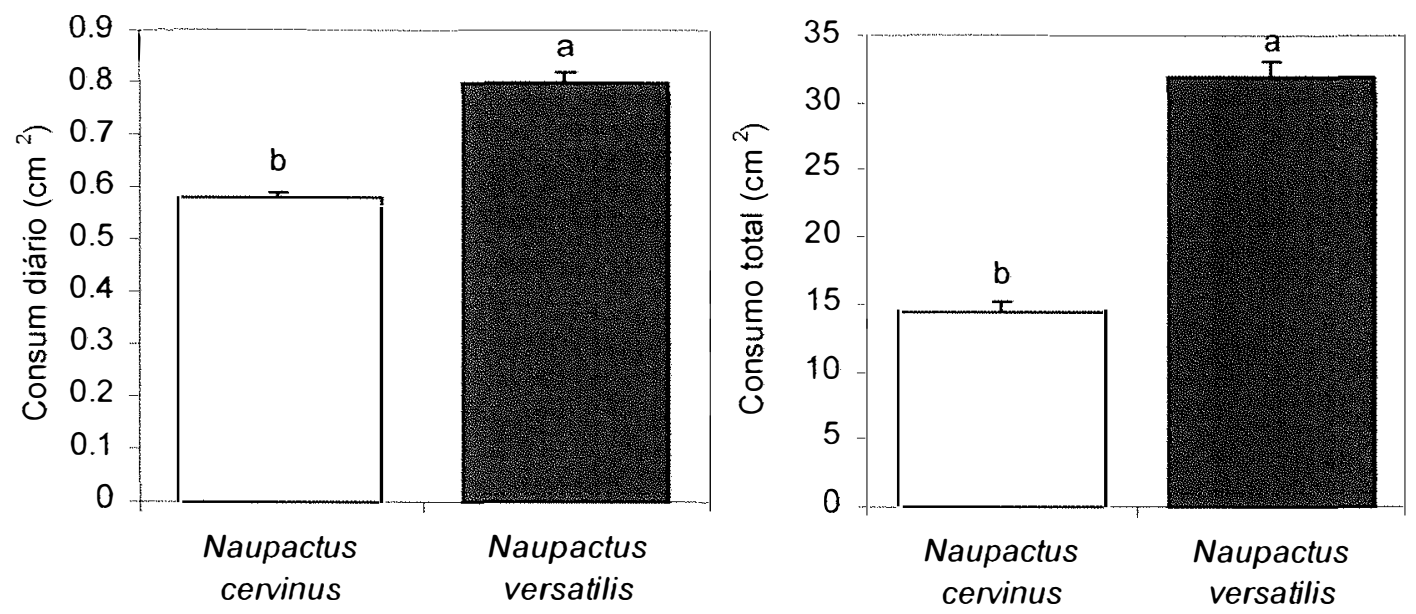

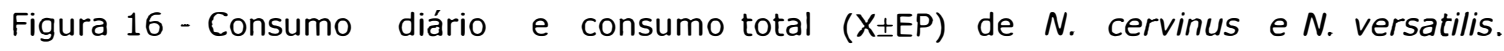
Temperatura $25 \pm 1^{\circ} \mathrm{C}$, UR $80 \pm 10 \%$ e fotofase de $14 \mathrm{~h}$. Médias seguidas por letras desiguais diferem entre si, pelo teste Tukey ao nivel de $5 \%$ de probabilidade.

\subsubsection{Ciclo biológico}

O ciclo completo das espécies de curculionídeos-das-raízes, variou de seis a 10 meses. N. cervinus apresentou a fase de ovo variável de 19 a 40 dias e um período larvapupa de 143 a 200 dias, dependendo do porta-enxerto utilizado como hospedeiro, totalizando um período de ovo a adulto de 162 a 240 dias; os adultos viveram em média 25 dias. Para $N$. versatilis, a fase de ovo durou de 20 a 39 dias e o período larva-pupa 230 dias, totalizando um período de ovo a adulto de 250 a 269 dias; os adultos dessa espécie viveram em média, 31 dias (Figura 17). Essas durações de ciclos não permitem assegurar a ocorrência de duas gerações por ano, permitindo inferir que tanto $N$. cervinus quanto $N$. versatilis são univoltinos, como a maioria dos Naupactini que ocorrem na Argentina (Lanteri et al., 1994), no Uruguai (Alzugaray et al., 1998), nos EUA (Flórida) e nas Antilhas, Woodruff (1985). Entretanto, entre os Naupactini foram observadas diferentes durações de ciclo, até mesmo para a mesma espécie, como por exemplo $N$. leucoloma, que dependendo do clima da região de ocorrência pode ser bivoltino ou univoltino (Hardwick \& Prestidge, 1994); por outro lado, 
nas regiões tropicais e subtropicais podem ocorrer espécies de Naupactus com duas gerações por ano (Lanteri et al., 2002). De outro lado, A. floridanus apresenta um período de ovo a adulto de 101 dias em média (McCoy et al., 1985), bastante abaixo do verificado para a maioria dos Naupactini da América do Sul, comprovando assim a variação existente no grupo.

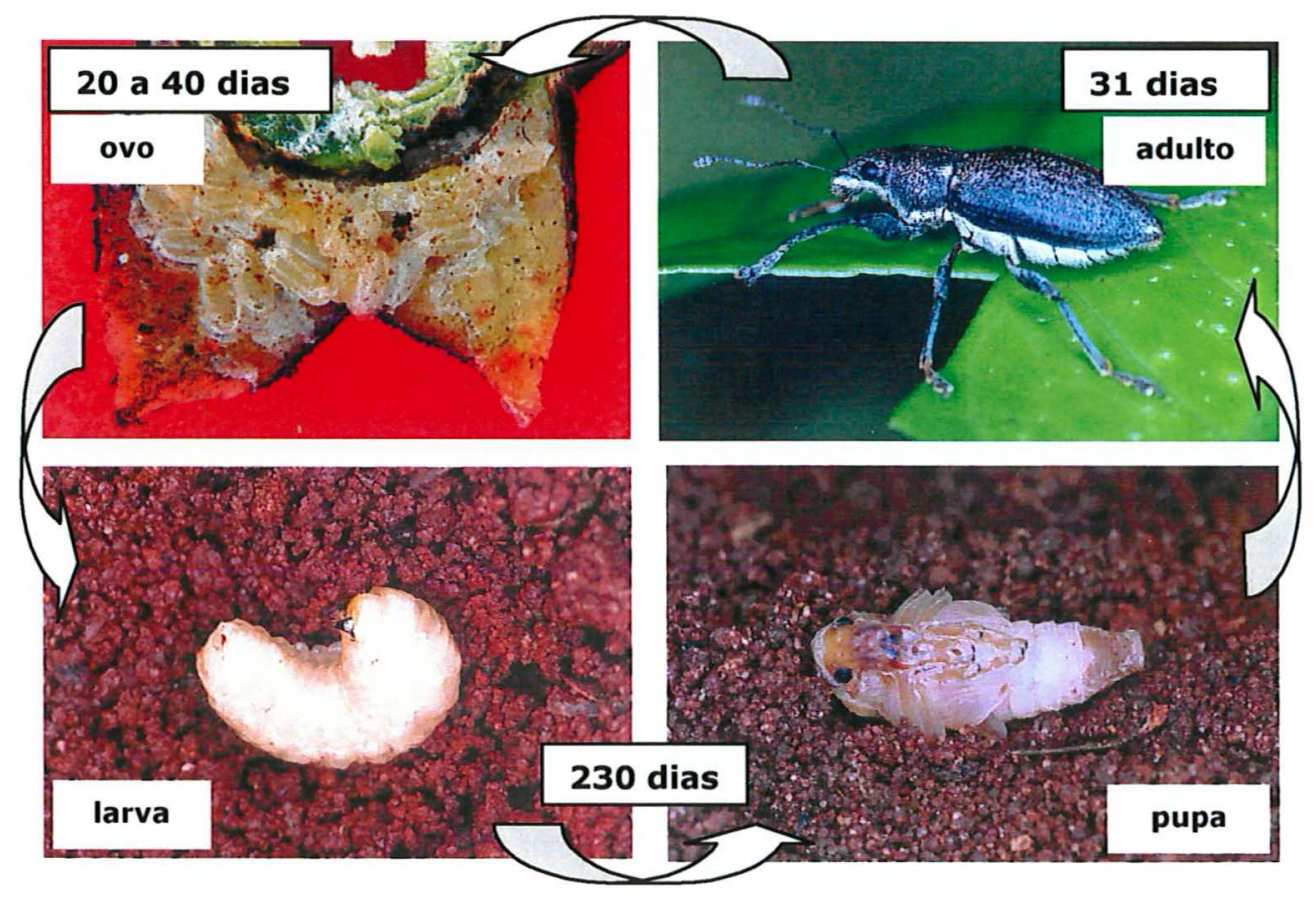

Figura 17 - Duração das fases e ciclo biológico de Naupactus versatilis em citros.

\subsection{Conclusões}

- As espécies de curculionídeos-das-raízes dos citros apresentam diferenças nas características biológicas, no comportamento de oviposição e no potencial de danificar os citros;

- Os limiares térmicos inferiores de desenvolvimento e respectivas constantes térmicas variam com a espécie; 
- A postura dos curculionídeos-das-raízes dos citros é realizada em fendas estreitas, sob o cálice do fruto, independente da sua cor, e também em resíduos vegetais e no solo;

- O porta-enxerto influencia na duração do período larva-pupa de Naupactus cervinus Boheman, sendo mais longo em Citrumelo Swingle;

- Naupactus versatilis Hustache e $N$. versatilis e são univoltinos e apresentaram cinco ínstares larvais, com um ciclo mais longo para a primeira espécie;

- A espécie $N$. versatilis é potencialmente mais prejudicial aos citros, pois coloca maior número de ovos, apresenta maior longevidade e consome maior área foliar do que $\mathbf{N}$. cervinus. 


\section{FLUTUAÇÃO POPULACIONAL DOS CURCULIONÍDEOS-DAS-RAÍZES DOS CITROS}

\section{Resumo}

O objetivo deste trabalho foi estudar a flutuação populacional dos curculionídeos-das-raízes dos citros e a distribuição das posturas na planta das principais espécies coletadas em São Paulo. Foram feitas amostragens quinzenais das fases de ovo, larva, pupa e adulta, em quatro fazendas de citros, em Itapetininga-SP, no período de março de 2000 a fevereiro de 2002. A emergência de adultos foi quantificada em gaiolas sob a copa das plantas e a população de adultos, na copa das plantas com pano-debatida; a fase de ovo foi avaliada nos frutos e as larvas e pupas em trincheiras abertas no solo, sob a copa das plantas. A distribuição das posturas foi avaliada em frutos de diferentes partes da copa da planta. Com base em sua flutuação populacional, os insetos são univoltinos. A maioria dos adultos emergiu de outubro a abril, com picos no início de período.. As espécies Naupactus cervinus Boheman e Naupactus versatilis Hustache foram as mais freqüentes em Itapetininga, SP, embora com picos em épocas diferentes. Em campo, as posturas foram encontradas nos frutos, entre o cálice e a casca do fruto, em maior número, no interior e nos terços médio e inferior da copa. Ocorreram larvas praticamente o ano inteiro, com picos populacionais no período de junho a janeiro. 0 número de curculionídeos foi menor no segundo ano do estudo, para todas as fases estudadas, conseqüência, provavelmente da estiagem. Dentre as fases estudadas, os adultos e as larvas, amostrados, respectivamente, com pano-de-batida e em trincheiras no solo, podem servir para a deteç̧ão, quantificação e previsão da ocorrência dos curculionídeos-das-raízes dos citros. 


\section{Summary}

The goal of this work was to study the population dynamics of citrus root weevils and the distribution of egg layings in the plant of main species collected in São Paulo. Samples of the egg, larva, pupa and adult stages were taken fortnightly in four citrus farms in Itapetininga, SP, between March, 2000 and February, 2002. The emergence of adults was quantified in cages under plant crowns and the adult population at plant crowns with a beating cloth; the egg stage was evaluated in the fruit and the pupae in ditches opened in the soil, under plant crowns. Based on the population dynamics, the insects are univoltine. Each stage of the cycle has a population peak at different times, which makes it easier to control. Most adults emerged from October to April, with peaks at the beginning of the period. Species Naupactus cervinus Boheman and Naupactus versatilis Hustache were more frequent in Itapetininga, SP, although the peaks and times were different. In the field, the eggs were found in the fruits, in a larger number between the the fruit calyx and peel, inside the fruit and in the central and lower third parts of the crown. Larvae occurred nearly throughout the year, with population peaks in the period of June through January. The number of curculionids was lower in the second year of study for every stage studied, probably due to drought. In the studied stages, the adults and larvae sampled, respectively, with beating cloths and in ditches can be used for detecting, quantifying and predicting the occurrence of citrus root weevils.

\subsection{Introdução}

A cultura dos citros é de grande importância para a economia brasileira, especialmente para a região sudeste do Brasil, onde está localizada $80 \%$ da área cultivada do país e, praticamente, todo o parque agroindustrial do setor citrícola. Essa região apresenta altos níveis de tecnologia, que aliados ao seu excelente nível de 
competitividade, posicionam o Brasil como o maior produtor de frutos e o maior exportador mundial de suco concentrado de laranja (FNP Consultoria e Comércio, 2002).

A cultura dos citros apresenta uma série de problemas fitossanitários, que podem comprometer sua produção, como os ácaros e os insetos-praga. Dentre esses problemas, os curculionídeos-das-raízes têm sido considerados pragas secundárias para a citricultura, embora em algumas regiões dos estados de São Paulo e de Minas Gerais, ganhem "status" de pragas primárias da cultura (Guedes et al., 2002), tanto pelos danos diretos causados pelas larvas às raízes das plantas, quanto pelos ferimentos que facilitam a entrada de patógenos, como Phytophthora spp. Os adultos dos curculionídeos-das-raízes ocorrem praticamente o ano inteiro, mas as maiores populações são observadas a partir de setembro, até maio do ano seguinte. Na copa da planta, as fêmeas ovipositam sob o cálice dos frutos; as larvas eclodem e se desenvolvem no solo, sendo verificadas praticamente o ano inteiro; consomem radicelas, raízes finas e a casca das raízes mais grossas. As maiores populações de pupas são encontradas de agosto a dezembro (Guedes, 2001). Apesar destas observações biológicas, muitos aspectos relacionados à ecologia desse grupo foram pouco estudados ou são ainda desconhecidos.

Este trabalho teve por objetivo estudar a flutuação populacional das fases de ovo, larva, pupa e adulta dos curculionídeos-das-raízes dos citros, visando desenvolver estratégias para o manejo desse grupo de pragas.

\subsection{Material e Métodos}

Foram feitas amostragens das fases de ovo, larva, pupa e adulta dos curculionídeos-das-raízes dos citros, em quatro fazendas da Empresa Citrovita, em Itapetininga-SP, de março de 2000 a fevereiro de 2002. Os locais de amostragem foram escolhidos por apresentarem histórico de ocorrência dos Naupactini, além de diferenças com relação ao tipo de solo, porta-enxerto e copa das plantas, sendo todas as áreas 
cultivadas com laranjeiras de 11-12 anos de idade (Tabela 1). Os dados climáticos foram coletados na Fazenda Umuarama, contígua às áreas experimentais, que distam entre 8 e 10 km da estação meteorológica.

Em cada fazenda, foi selecionada uma área de 0,7 a 1,0 ha, onde foram feitas as amostragens de insetos e foram aplicados todos os tratos culturais recomendados, exceto pulverizações visando ao controle de insetos e ácaros. Para a avaliação da ocorrência das diferentes fases dos insetos, as amostragens foram feitas ao acaso, em dois locais a cada semana (Tabela 1), correspondendo a duas amostragens por mês, ou seja, uma amostragem em cada quinzena, por fazenda.

Tabela 1. Locais de amostragem dos curculionídeos-das-raízes e respectivos tipo de solo e material vegetal dos pomares de citros. Itapetininga, SP, no período de 03/2000 a 02/2002.

\begin{tabular}{llcc}
\hline $\begin{array}{c}\text { Local } \\
\text { (fazenda) }\end{array}$ & Tipo de solo* & Laranjeira & Copa \\
\hline Campo de Aviação & Latossolo vermelho escuro & Limão cravo & Pêra \\
Vaca Morta & Latossolo vermelho escuro & Limão volkamer & Natal \\
Olho D'água & Podzólico vermelho-amarelo & Limão cravo & Pêra \\
Velha & Podzólico vermelho-amarelo & Limão cravo & Natal \\
\hline *(Rizzo et al., 1992) & & &
\end{tabular}

Os dados resultantes das 48 amostragens quinzenais, em cada uma das quatro áreas, foram agrupados, mês a mês, para comporem as figuras de flutuação populacional das diferentes fases do ciclo biológico dos curculionídeos-das-raízes dos citros.

\subsubsection{Emergência de adultos e flutuação populacional de adultos na copa}

Na área experimental de cada local (fazenda) foram dispostas dez gaiolas, junto ao solo, sob a copa de plantas, escolhidas ao acaso e a emergência de adultos dos 
curculionídeos-das-raízes dos citros foi avaliada através da contagem dos insetos presentes nessas gaiolas. As gaiolas mediam 4,0 × 4,0 m, com $0,1 \mathrm{~m}$ de altura, confeccionadas com tela anti-afídeos, com as estruturas laterais de madeira; junto ao tronco, a tela foi amarrada com arame, impedindo a fuga de adultos (Figura 1a). A cada seis meses, as gaiolas foram trocadas de planta pois se elas fossem mantidas impediriam, que as larvas recém eclodidas atingissem o solo, reduzindo a população dos curculionídeos, naquela planta.

O levantamento populacional dos adultos presentes na copa das plantas foi efetuado utilizando-se um pano-de-batida $(4,0 \times 4,0 \mathrm{~m})$, confeccionado de tela antiafídeos. O pano-de-batida era introduzido sob a copa e as plantas vigorosamente chacoalhadas, procedendo-se à contagem e identificação das espécies dos curculionídeos que caíam no pano. Em cada fazenda, uma vez por quinzena, foi amostrada a população de insetos em dez plantas, escolhidas ao acaso, dentro da área experimental.

Foi realizada a análise da correlação entre número médio de adultos que emergiram nas gaiolas com precipitação pluviométrica e temperatura do ar, do mês e do mês anterior à coleta, através do teste t a $5 \%$ de probabilidade.

\subsubsection{Flutuação populacional de ovos e sua distribuição na planta}

O levantamento da oviposição dos Naupactini dos citros foi feito através da amostragem 50 frutos/local/quinzena, em plantas escolhidas ao acaso nos pomares das quatro fazendas. Os frutos foram levados para o Laboratório de Biologia de Insetos do Departamento de Entomologia, Fitopatologia e Zoologia Agrícola da ESALQ/USP, em Piracicaba-SP, onde os ovos foram contados, sob microscópio estereoscópico.

Nas mesmas áreas também foram feitas as observações de campo visando a descrição e caracterização da oviposição, além da coleta de folhas, ramos e frutos para estudar a distribuição das posturas na planta. 
Para estudo da distribuição das posturas na planta, as partes vegetais foram coletadas, ao acaso, em maio e em outubro de 2000 respectivamente nas áreas, com ocorrência de $N$. cervinus e de $N$. versatilis. Cada uma das áreas foi selecionada por apresentar ocorrência exclusiva de cada uma das espécies de Naupactini em estudo (Guedes inf. pessoal, 2000).

No Experimento $A$, para avaliar a distribuição dos ovos nas diferentes estruturas da planta, foram coletados 100 frutos "grandes" ( $\geq 6 \mathrm{~cm}$ de diâmetro), 100 frutos "pequenos" ( $\leq 2,5 \mathrm{~cm}$ de diâmetro), 100 folhas normais, 100 folhas encarquilhadas pelo ataque de pulgões e 100 partes terminais dos ramos (10 $\mathrm{cm}$ de comprimento) em cada uma das áreas.

No Experimento B para avaliar a distribuição espacial das posturas na planta, foram coletados 500 frutos, sendo 100 de cada terço da planta (superior, médio e inferior); 100 frutos da periferia e 100 do interior da copa da planta. Em ambos os experimentos de campo, os frutos, folhas e ramos foram levados ao Laboratório de Biologia de Insetos, onde foram examinados sob microscópio esteroscópico e o número de ovos contados. Os resultados foram submetidos à análise da variância e as médias comparadas pelo teste de Tukey, ao nível de $5 \%$ de probabilidade.

\subsubsection{Flutuação populacional de larvas e pupas}

A amostragem de larvas e pupas dos curculionídeos-das-raízes dos citros foi feita pela inspeção e contagem do número de insetos presentes no solo retirado e peneirado de uma trincheira $(0,15 \times 2,0 \mathrm{~m}$ de comprimento e $0,30 \mathrm{~m}$ de profundidade), medindo, 0,3 $\mathrm{m}^{2}$, feita sob a copa da planta, do tronco até a linha de projeção da copa, aproximadamente (Figura 1C). Na área experimental de cada local foram avaliadas dez trincheiras por quinzena, de plantas escolhidas ao acaso. Os insetos foram agrupados como Naupactini, dada a impossibilidade de separar, em campo, as espécies por meio de larvas e pupas. 


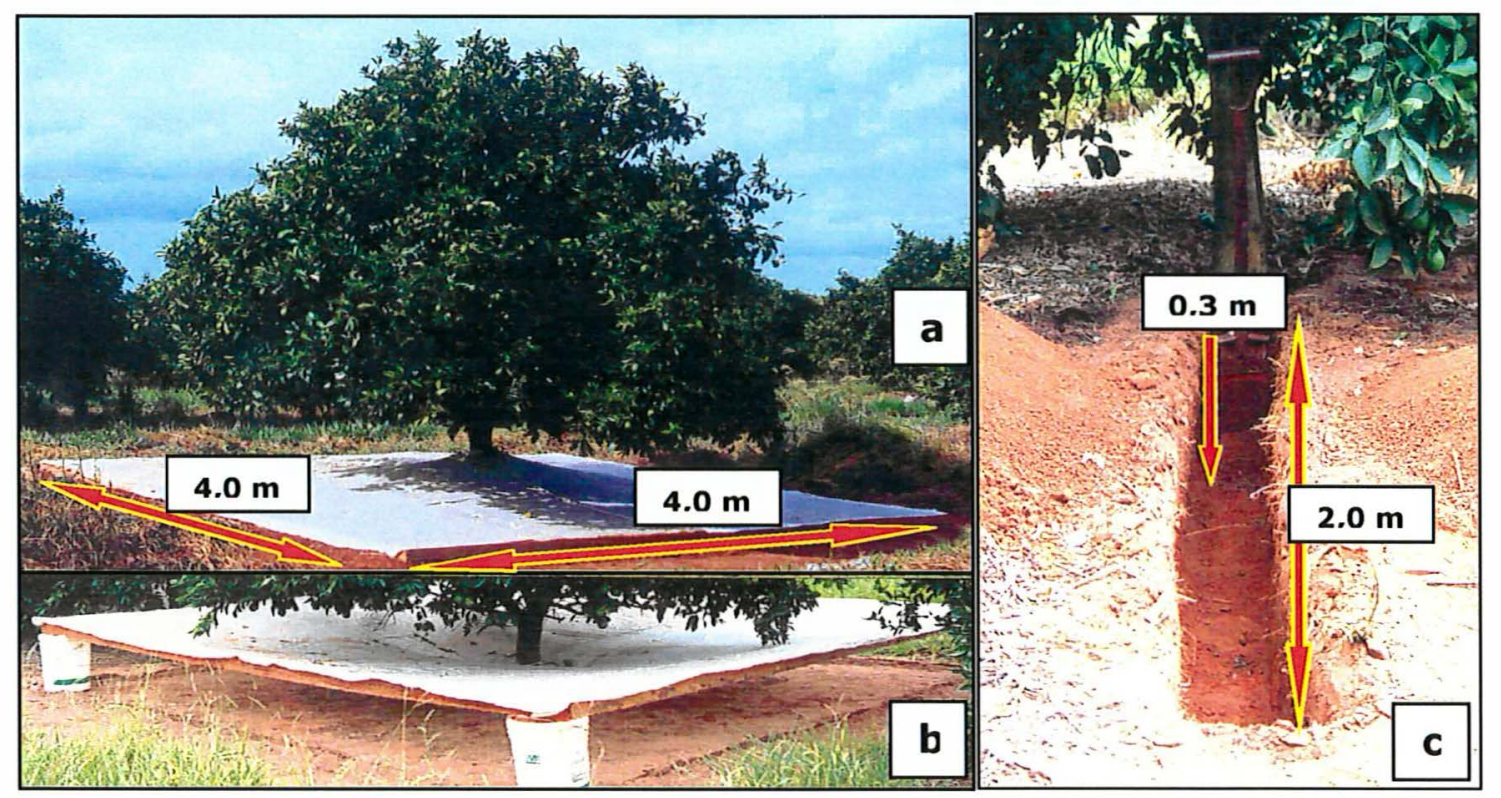

Figura 1 - Amostragem de larvas, pupas e adultos dos curculionídeos-das-raízes dos citros: a) Gaiola de emergência de adultos, b) Gaiola afastada do solo para a amostragem e c) Trincheira para a amostragem de larvas e pupas. Itapetininga, SP.

\subsection{Resultados e Discussão}

O levantamento populacional das diferentes fases do ciclo evolutivo dos curculionídeos-das-raizes dos citros, indicaram claramente que eles apresentam um ciclo evolutivo anual, sendo univoltinos, e com picos populacionais bem definidos, para os diferentes estágios (Figuras 2 e 4 e Figura 8 e 9). O conhecimento da ocorrência das diferentes fases do ciclo dos curculionídeos-das-raizes em uma determinada época, associada ao conhecimento da vulnerabilidade das diferentes fases e da adequação das técnicas de controle, permite programar de forma mais eficiente e econômica o manejo desse grupo de pragas. 


\subsubsection{Emergência de adultos e flutuação populacional de adultos na copa}

Pela estatística descritiva da ocorrência dos adultos dos curculionídeos-dasraízes dos citros, nas gaiolas de emergência, apresentou variação entre os anos do estudo e entre as fazendas estudadas. Independente do tamanho da população, os picos populacionais geralmente ocorreram de outubro a dezembro, emergindo a maior parte da população, até abril (Figura 2). De forma análoga, Ripa (1992) observou que a população de adultos de Naupactus xanthographus (Germar) apresenta dinâmica populacional similar, em diferentes locais, por anos consecutivos, na cultura da videira, no Chile. Segundo o mesmo autor, esse comportamento deriva da característica da espécie, cuja fase de pupa se desenvolve no solo, contribuindo para uniformizar a emergência.

Comparando o primeiro e o segundo ano de coleta de adultos, nas gaiolas de emergência, observou-se um maior intervalo, sem emergência, no primeiro ano, para $N$. versatilis e $P$. fluctuosus das três espécies estudadas. Esse período mais longo sem emergência, possivelmente esteja relacionado aos baixos indices pluviométricos verificados entre março e julho de 2000 e às temperaturas médias mais baixas, observadas entre maio a setembro do mesmo ano, comparados ao mesmo período do ano seguinte, no qual ocorreram adultos na maioria dos meses do ano (Figura 2). Segundo Loiácono \& Marvaldi (1994) o déficit hídrico no solo promove atraso no desenvolvimento larval, retardando a emergência dos Naupactini.

A menor precipitação pluviométrica, resulta numa menor umidade do solo, que é um dos fatores mais importantes para os insetos com fases de larva e de pupa no solo (Silveira Neto et al., 1976). Por outro lado, menores temperaturas também podem contribuir para o prolongamento da fase larval e conseqüentemente para a não emergência em alguns meses do ano, atrasando o aparecimento de adultos no campo. Dessa forma, a emergência dos Naupactini, nos mesmos períodos em anos sucessivos, possivelmente tenha relação mais estreita com condições climáticas favoráveis, do que com a disponibilidade de alimentos ou de locais de oviposição. Esses dois últimos fatores 
são abundantes em culturas perenes como os citros, em oposição às culturas anuais nas quais os recursos estão disponíveis por menor tempo, no campo.

Os picos de emergência de Naupactus cervinus Boheman, de Naupactus versatilis Hustache e de Parapantomorus fluctuosus (Boheman), ocorreram, com maior freqüência, entre outubro e dezembro; no entanto, $N$. cervinus apresentou um pico populacional também em março de 2000 além de exibir as maiores populações nos dois anos e em todas as áreas estudadas, com picos de até sete insetos/planta/mês. Esses fatos, aliados à coleta de $N$. cervinus durante nove meses do ano, exceto no período de julho a setembro, pode ser uma indicação da maior adaptação da espécie às condições climáticas locais (Figura 3a).

O conhecimento da época em que há uma maior concentração de adultos poderá levar ao planejamento da adoção das práticas de controle num período mais curto de tempo. A associação deste conhecimento com o efeito climático, atrasando ou antecipando a ocorrência da praga, permitirá a previsão de tal ocorrência, facilitando o seu controle.

No presente trabalho, as espécies $N$. cervinus e $N$. versatilis foram predominantes em relação à $P$. fluctuosus e muito mais freqüentes do que Naupactus ambiguus Boheman, Naupactus navicularis Boheman, Naupactus tarsalis Boheman e Teratopactus nodicollis (Boheman), espécies pouco observadas na área de estudo. Entretanto, quanto se estudou a distribuição das espécies nos estados de São Paulo e Minas Gerais (item 3.3.3), P. fluctuosus foi observada em um maior número de localidades cultivadas com citros (23 municípios), seguida de $N$. versatilis (14 municípios) e de $N$. cervinus (6 municípios). Apesar da ampla distribuição de P. fluctuosus (item 3.3.3), indicando uma maior adaptação dessa espécie à citricultura do sudeste do Brasil, quando comparada à $N$. cervinus e $N$. versatilis, em Itapetininga, SP, foi observada em menor quantidade, indicando que devem existir fatores locais (climáticos, edáficos, varietais, etc) limitantes à espécie. 

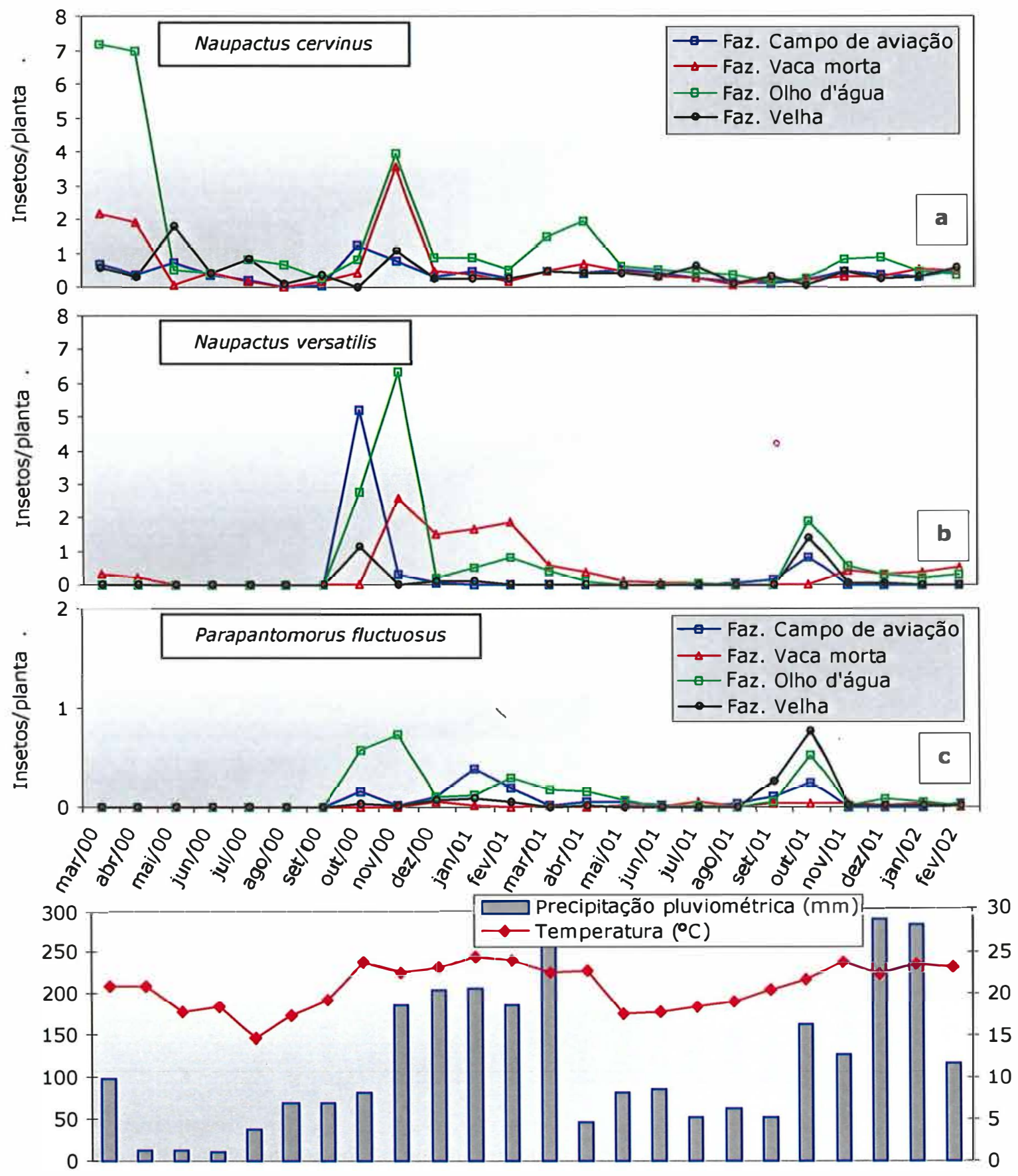

Figura 2 - Flutuação populacional dos adultos dos curculionídeos-das-raízes nas gaiolas de emergência, em quatro fazendas de citros, no município de Itapetininga, SP, com a precipitação pluviométrica e temperatura média do período de 03/2000 a $02 / 2002$. 
A correlação entre os insetos que emergiram nas gaiolas com precipitação pluviométrica do próprio mês ou do mês anterior, somente foi significativa, em duas das doze possibilidades testadas (Tabela 2); entretanto, a maioria parte dos curculionídeos emergiu nas estações mais quentes e chuvosas dos anos estudados, permitindo inferir que, além da temperatura, da precipitação pluviométrica do período ou da precipitação pluviométrica acumulada, outros fatores, como a temperatura do solo e a duração do ciclo das espécies, contribuem para determinar tal emergência.

A estatística descritiva da ocorrência de adultos dos curculionídeos-das-raízes na copa das laranjeiras, também variou entre os locais estudados nos dois anos de observação. As maiores populações foram observadas entre outubro e abril (Figura 3). De modo similar à emergência, os efeitos da temperatura e da precipitação pluviométrica deficiente, refletiram no número de insetos observados na parte aérea das plantas.

As três espécies observadas apresentaram diferenças na dinâmica e nos picos populacionais. No primeiro ano de observação, $N$. cervinus apresentou picos populacionais de adultos na copa, no período entre dezembro e abril e $N$. versatilis apresentou picos populacionais no período entre outubro e fevereiro. Em alguns casos, os picos populacionais das espécies se sucederam, mantendo a população de adultos elevada na copa das plantas, por períodos mais longos do que os picos de ocorrência, agravando o

Tabela 2. Correlação linear ( $r$ ) entre o número médio de curculionídeos-das-raízes dos citros emergidos nas gaiolas e as médias mensais de precipitação pluviométrica.

\begin{tabular}{lcccc}
\hline \multirow{2}{*}{ Espécie } & \multicolumn{2}{c}{$\begin{array}{c}\text { Precipitação pluviométrica } \\
\text { do mês }\end{array}$} & \multicolumn{2}{c}{$\begin{array}{c}\text { Precipitação pluviométrica } \\
\text { do mês anterior }\end{array}$} \\
& $2000 / 01$ & $2001 / 02$ & $2000 / 01$ & $2001 / 02$ \\
\hline Naupactus cervinus & $-0,0263^{\mathrm{NS}}$ & $0,1322^{\mathrm{NS}}$ & $0,0514^{\mathrm{NS}}$ & $0,5965^{*}$ \\
Naupactus versatilis & $0,4535^{\mathrm{NS}}$ & $0,2863^{\mathrm{NS}}$ & $0,1841^{\mathrm{NS}}$ & $-0,0735^{\mathrm{NS}}$ \\
Parapantomorus fluctuosus & $0,7267^{*}$ & $0,0572^{\mathrm{NS}}$ & $0,5586^{\mathrm{NS}}$ & $-0,3019^{\mathrm{NS}}$ \\
\hline * significativo e & & & & \\
\hline
\end{tabular}

* significativo e ${ }^{\text {NS }}$ não significativo a $5 \%$ pelo teste $T$. 

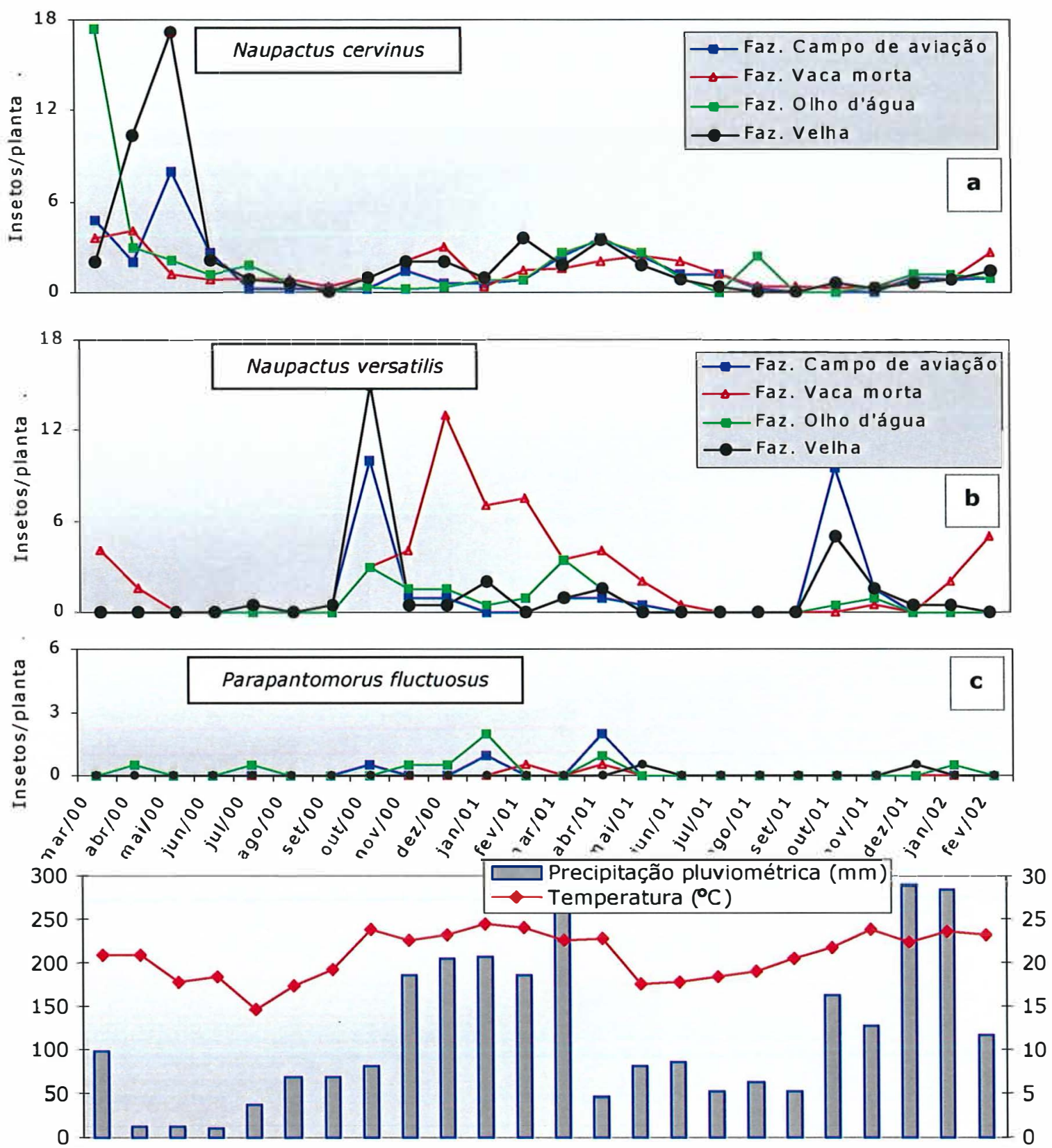

Figura 3 - Flutuação populacional dos adultos dos curculionídeos-das-raízes na copa das plantas, em quatro fazendas de citros, no município de Itapetininga, SP, com a precipitação pluviométrica e temperatura média do período de 03/2000 a $02 / 2002$. 
problema da praga (Figura 3a e 3b). Essa sucessão de picos populacionais com espécies diferentes ocorrendo em épocas distintas, dificulta a estratégia de controle e prolonga os levantamentos populacionais para a adoção de tais medidas. De forma similar, Lanteri \& Aragón (1994) observaram que as populações de Atrichonotus taeniatulus (Berg), de Naupactus leucoloma Boheman e de Pantomorus auripes Hustache sucederam-se no tempo, como forma de maximizar o aproveitamento de recursos, na cultura da alfafa. $\mathrm{Na}$ mesma cultura, Brewer \& Varas (1974) verificaram sucessão de picos populacionais de $A$. taeniatulus e de Naupactus cinereidorsum Hustache.

Nos citros, como há disponibilidade constante de alimento, a ocorrência de adultos em épocas diferentes, é uma conseqüência da variação da duração das fases imaturas, em função da temperatura e da umidade do solo, da qualidade e da quantidade de alimento disponível às larvas, além de condições climáticas favoráveis da fase de pupa até a ocorrência dos adultos na superfície do solo.

O número de adultos na copa foi, aproximadamente, 2,5 vezes maior do que a emergência de $\boldsymbol{N}$. cervinus e de $\boldsymbol{N}$. versatilis, sugerindo que devido à longevidade dos curculionídeos, a mesma população foi contada em duas ou mais amostragens, e que em campo, os insetos possivelmente vivam mais do que os 30 dias, verificados para $N$. cervinus e $N$. versatilis, em laboratório (item 4.3.3). Por sua vez, a adversidade climática, verificada no primeiro ano de observação, resultou em efeitos mais severos sobre a população de $\boldsymbol{N}$. cervinus do que sobre a população de $\boldsymbol{N}$. versatilis (Figura 3 a e 3b), possivelmente em decorrência da coincidência dos seus picos populacionais, com o período de maior restrição hídrica (Figura 3a).

A ocorrência de picos de emergência dos curculionídeos-das-raízes e a presença de adultos na copa, em épocas comuns, ou próximas, por anos seguidos, facilita a adoção de práticas de controle dos adultos dos curculionídeos-das-raízes dos citros, nas citadas épocas. Nos dois anos do estudo, a população de adultos observada na copa das plantas, ultrapassou os niveis de controle empiricamente adotados pelos produtores de citros (cinco a dez insetos/planta). Dada a escassez de resultados sobre o assunto, 
justifica-se a condução de pesquisas visando determinar o nível de controle para este grupo de insetos-praga dos citros, com base no sistema de amostragem de larvas e de adultos, utilizado no presente trabalho.

\subsubsection{Flutuação populacional de ovos e distribuição na planta}

A flutuação populacional de ovos dos Naupactini dos citros foi discutida conjuntamente, dada a impossibilidade de separação nessa fase, das diferentes espécies que ocorreram nas áreas estudadas. O número de ovos variou ao longo dos dois anos de estudo nas áreas avaliadas, (Figura 2). Foram encontrados ovos, na maioria dos meses do ano, nos pomares das quatro fazendas avaliadas.

No segundo ano do estudo, os picos populacionais de ovos apresentaram valores menores e foram mais dispersos, ocorrendo de março de 2001 a fevereiro de 2002, com posturas inclusive nos meses de junho e julho, nas diferentes áreas avaliadas, época normalmente inadequada para esta fase de desenvolvimento do inseto. Os valores médios mensais do segundo ano, raramente ultrapassaram três ovos/fruto, sendo, portanto menores do que os valores verificados no primeiro ano, como conseqüência da redução do número de adultos nos pomares, causado pela estiagem (Figura 4). Curiosamente, o pico populacional de adultos na copa, no período entre outubro e dezembro de 2000, não teve reflexo no número de posturas, provavelmente também devido à estiagem, sugerindo que as fêmeas retardam a postura até surgirem condições de umidade favoráveis.

Os estudos sobre a flutuação populacional da fase de ovo dos Naupactini são raros e incompletos, possivelmente devido às dificuldades de localização e identificação das posturas desse grupo de pragas, ao desconhecimento dos diversos sítios de oviposição (Guedes et al. 2001), e pela diversidade de comportamentos e de espécies que ocorrem nos citros, ovipositando na parte aérea de planta, no solo e nos seus resíduos. 


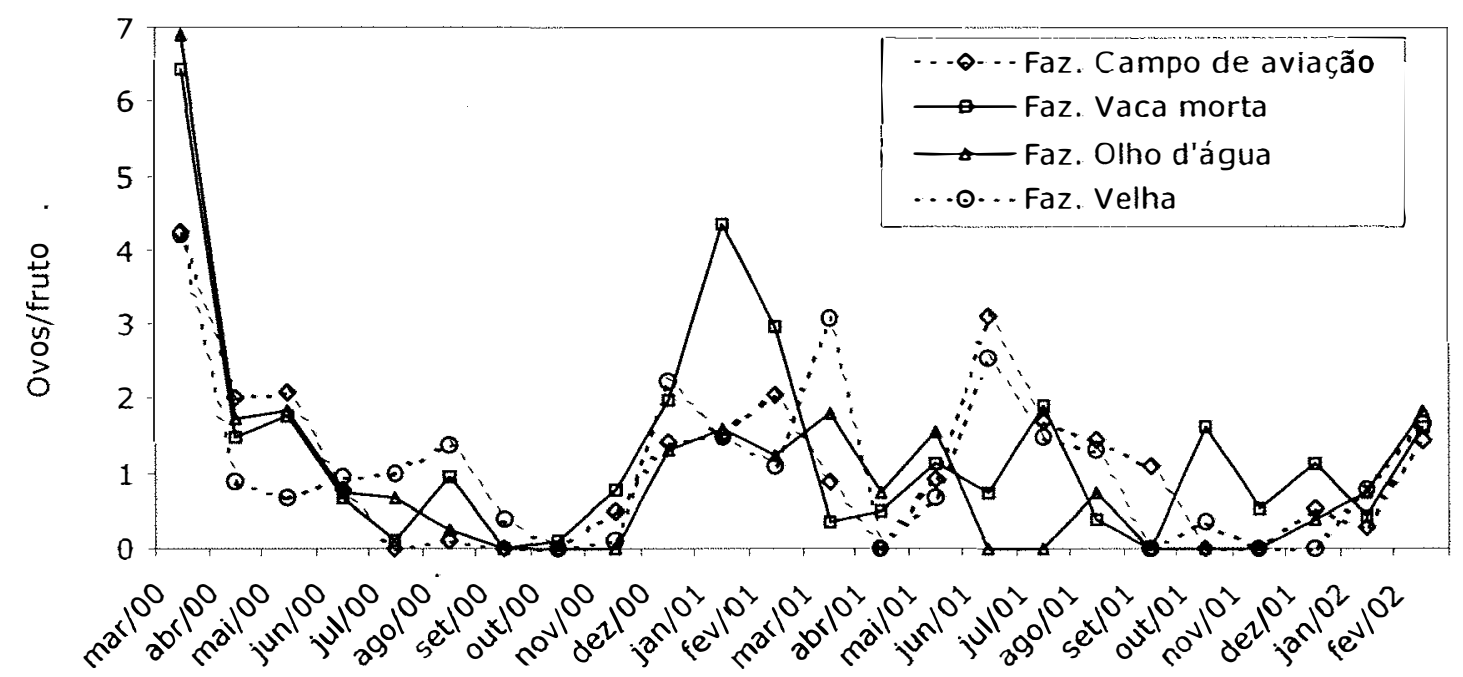

Figura 4 - Flutuação populacional da fase de ovo dos curculionídeos-das-raizes, coletados em citros, em quatro fazendas no município de Itapetininga, SP, de 03/2000 a $02 / 2002$.

O conhecimento da oviposição das espécies predominantes e da época de ocorrência dos adultos, associados a imobilidade da fase de ovo, poderia facilitar o monitoramento dos Naupactini dos citros, através da amostragem dessa fase de desenvolvimento; todavia, a ocorrência de posturas em residuos na superfície do solo e no próprio solo, dificultam sua deteç̧ão e contagem. Foram encontradas posturas nos frutos, entre o cálice e a casca, com os ovos distribuidos sob as sépalas, ao redor da inserção do pedúnculo, sendo difíceis de serem visualizadas a olho nu (Figura 5 a e b). Em observações feitas aleatoriamente, em campo, além das posturas verificadas nos frutos, raramente foram observadas posturas em folhas encarquilhadas devido ao ataque de pulgões (Figura 5c). No campo, também não foram observadas posturas em folhas normais, embora ocorram no laboratório, quando os insetos são confinados em gaiolas de criação.

Sob o pedúnculo de um mesmo fruto podem ocorrer posturas de diferentes idades, ou seja, ovos em desenvolvimento embrionário e posturas velhas, com larvas já eclodidas ou parasitadas, sugerindo que à medida que diminui a oferta de frutos livres de posturas, as fêmeas ovipositam também naqueles que já contêm ovos. Guedes et al. (2001) verificaram a ocorrência de Fidiobia citri (Nixon) e Fidiobia sp. (Hymenoptera: 

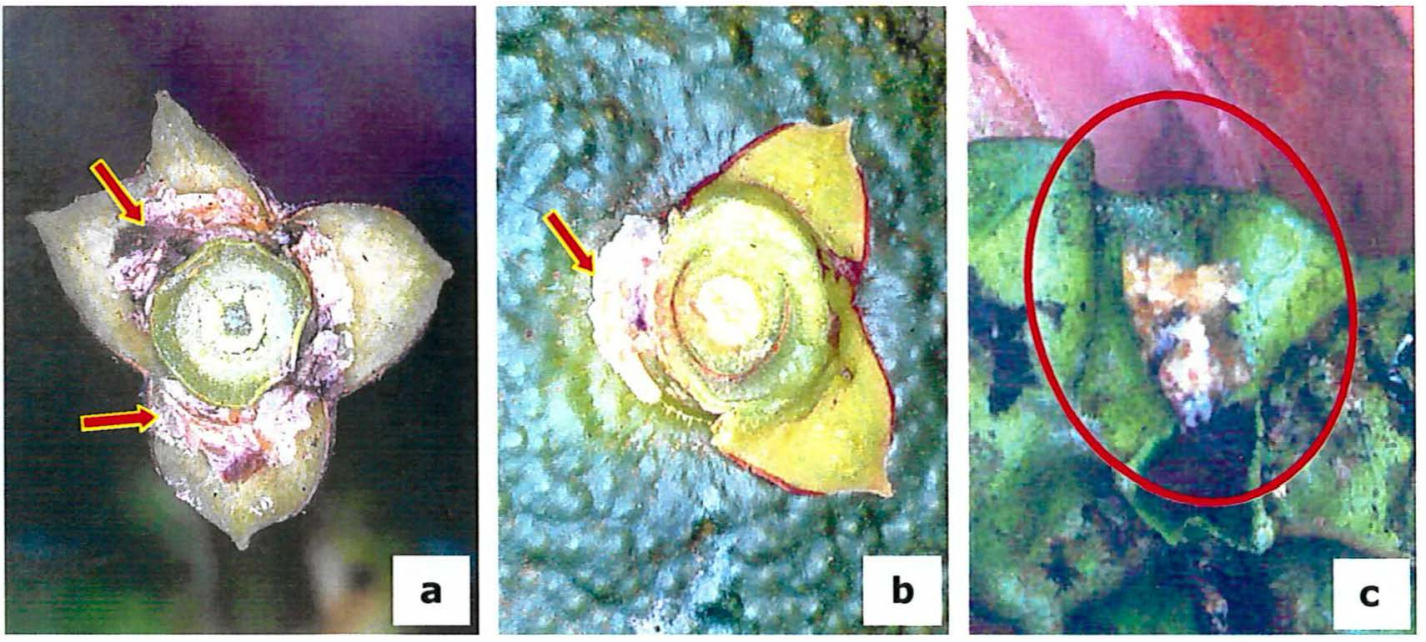

Figura 5 - Posturas dos curculionídeos-das-raizes; a) Sob o cálice destacado; b) Sobre a casca do fruto; c) Em folha encarquilhada pelo ataque de pulgões.

Platygastridae) parasitando posturas de Naupactus spp, em laranjas coletadas em Itapetininga, SP.

As posturas da maioria das espécies dos curculionídeos-das-raizes dos citros são feitas em massas de ovos, envoltas em uma substância adesiva, que favorece a acomodação dos mesmos e que, posteriormente seca e endurece, contribuindo para a proteção das posturas e aderência ao substrato. Segundo Soderstron \& Brandt (1992), uma hora após a oviposição, a substância que protege os ovos de $N$. cervinus endurece e torna-se insolúvel em água.

No material vegetal coletado, na área com ocorrência de $N$. versatilis e $N$. cervinus, a oviposição não diferiu entre espécies. Os frutos de maior tamanho na época ) "grandes" ( $\geq 6 \mathrm{~cm}$ de diâmetro) apresentaram o maior número de posturas, diferindo do valor observado nos frutos "pequenos" ( $\leq 2,5 \mathrm{~cm}$ de diâmetro) (Figura 6). Para ambas as espécies, não foram verificadas posturas nas folhas normais, nas folhas encarquilhadas e nem no extremo dos ramos das plantas cítricas, caracterizando comportamento de oviposição semelhante entre as espécies.

A oviposição dos Naupactini, na parte aérea da planta, exclusivamente nos frutos cítricos, possivelmente esteja condicionada à ocorrência das fendas, existentes 
entre o cálice e a superfície do fruto, e que apresentem dimensões adequadas à postura. Como os frutos maiores têm fendas menores e o número de ovos foi maior (Figura 6), aparentemente, essa característica física dos frutos é favorável à oviposição. A preferência dos Naupactini de ovipositarem nas fendas das plantas, foi relatada por Lanteri et al., (2002), embora algumas espécies ovipositem no solo e/ou em resíduos do solo (Marvaldi, 1999).

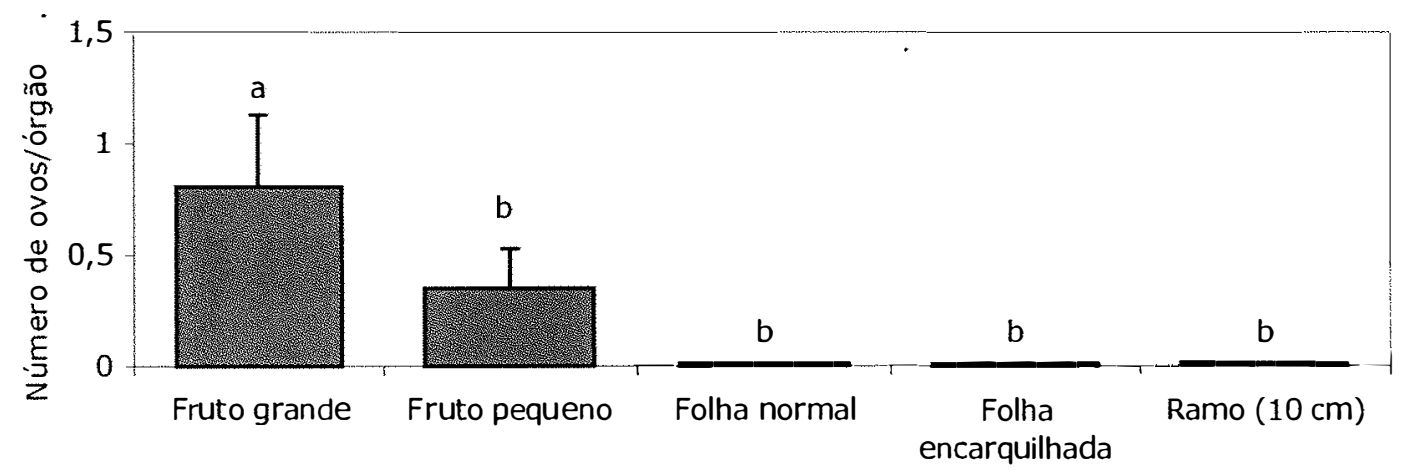

Figura 6 - Número de ovos de Naupactus cervinus e de $N$. versatilis (X士EP) em diferentes extratos da planta cítrica, em Itapetininga, SP. Médias seguidas de letras diferentes diferem entre si pelo teste de Tukey, ao nível de $5 \%$ de probabilidade.

Como o número de ovos, nos diferentes extratos da planta cítrica, não diferiu para espécies, os resultados referentes a $N$. cervinus e $N$. versatilis, serão discutidos conjuntamente. Não ocorreu diferença quanto ao número de ovos por fruto entre as diferentes alturas da planta, embora, numericamente, tenha sido verificada maior concentração de posturas nos terços médio ( 1,73 ovos/fruto) e inferior ( 1,86 ovos/fruto) da planta, em relação ao terço superior (0,96 ovos/fruto). Por outro lado, a maioria das posturas foi encontrada nos frutos localizados no interior da copa da planta $(2,25$ ovos/fruto), quando comparados com os da periferia da copa da planta (0,85 ovos/fruto) (Figura 7).

Quando as cinco sub-divisões da planta foram discutidos conjuntamente, foi possível verificar uma concentração numérica das posturas nos terços médio e inferior da planta e no interior da copa (próxima ao tronco), local que os adultos utilizam para 
subirem na planta. A maior concentração de posturas nesse local, entretanto, pode estar associada a outros fatores, como a menor quantidade de frutos situados no interior da copa da planta e do local propiciar maior abrigo e uma possível proteção às fêmeas contra inimigos naturais (Figura 7). Por sua vez, no terço inferior da copa da planta (saia da planta), ocorre a maior parte dos danos dos adultos às folhas, devido à maior concentração de insetos nesse local e, conseqüentemente, maior oviposição; o mesmo pode ser inferido para o terço médio da planta dada a sua proximidade com a parte inferior da copa das laranjeiras.

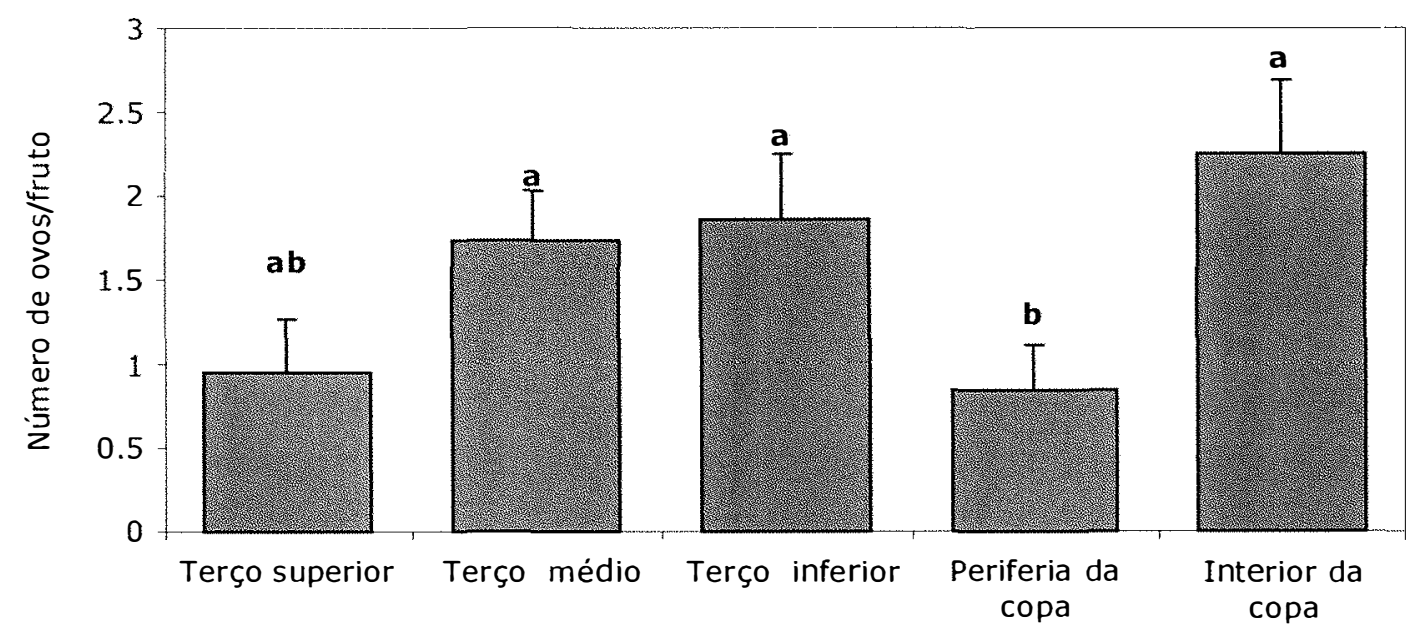

Figura 7 - Número de ovos de Naupactus cervinus e $N$. versatilis ( $\mathrm{X} \pm \mathrm{EP}$ ) em diferentes estruturas da planta cítrica, em Itapetininga, SP. Médias seguidas de letras diferentes diferem entre si pelo teste de Tukey, ao nível de $5 \%$ de probabilidade.

A distribuição dos ovos dos curculionídeos-das-raízes nos frutos, na parte central e nas partes média e inferior da planta, pode determinar que as práticas de amostragem de ovos e até mesmo pulverizações, devam ser realizadas, preferencialmente, nestes pontos ou dirigidas para estes locais, para se obter maior eficiência. 


\subsubsection{Flutuação populacional de larvas e pupas}

Dada a impossibilidade de identificar as espécies dos curculionídeos-das-raízes dos citros, em campo, através das suas larvas e pupas, as fases imaturas foram agrupadas e tratadas como Naupactini. A estatística descritiva população de larvas dos Naupactini oscilou ao longo do período de estudo, sendo encontradas larvas, praticamente, durante os 24 meses de avaliação, nas quatro fazendas estudadas, exceto na fazenda Olho d'água, no período entre janeiro e março de 2001 (Figura 8). Embora não sejam encontradas posturas no campo o ano inteiro, o longo e variável desenvolvimento larval dos curculionídeos-das-raizes dos citros (item 3.4.2) pode explicar a ocorrência de larvas durante todo o ano, fator que possivelmente favoreça a sobrevivência da espécie. De forma semelhante, De Jager et al (1989) observaram a ocorrência de larvas de diferentes idades de $N$. leucoloma, durante o ano todo, na África do Sul.

No primeiro ano do estudo, o pico de larvas ocorreu em agosto, nos quatro locais avaliados. A fazenda Vaca Morta, apresentou as maiores populações de larvas $\left(60 / 0,6 \mathrm{~m}^{2}\right)$, correspondendo a 1250 larvas por planta, aproximadamente. No segundo ano do estudo, os picos de larvas foram menos evidentes, ocorrendo de junho a janeiro, nas diferentes áreas avaliadas, com uma média abaixo de 30 larvas $/ 0,6 \mathrm{~m}^{2}$, portanto apresentando valores inferiores à metade da população verificada no primeiro ano.

Nos dois anos de amostragem, a fazenda Vaca Morta apresentou as maiores populações de larvas e a fazenda Olho d'água os menores, não sendo possível, no entanto, determinar a causa dessa variação, devido à diversidade de fatores envolvidos, tais como tipo de porta-enxerto e de copa, tipo de solo ou mesmo precipitação pluviométrica diferente entre as áreas/fazendas estudadas. Além desses fatores, as diferentes práticas de manejo adotadas podem também ter contribuído para promover as diferenças populacionais entre as áreas estudadas (Figura 8).

Pela estatística descritiva, a população de pupas dos Naupactini variou ao longo dos dois anos de amostragem. Nos meses de junho, julho e agosto de 2000, praticamente 
não foram encontrada pupas, com populações muito pequenas, nas quatro fazendas. $A$ partir de setembro, no entanto, a população aumentou, atingindo entre quatro e 11 pupas por $0,6 \mathrm{~m}^{2}$, que corresponderia a populações de 82 a 225 pupas por planta. No segundo ano do estudo, os picos populacionais de pupas foram menores, ocorrendo de setembro a fevereiro, nas diferentes áreas avaliadas. Os valores médios mensais não atingiram quatro pupas $/ 0,6 \mathrm{~m}^{2}$, portanto menores do que os valores verificados no primeiro ano (Figura 8).

Tanto a redução no número de larvas e de pupas, quanto a ocorrência de picos populacionais em diferentes épocas do ano, verificadas no segundo ano de avaliação, devem estar relacionadas à modificação do periodo de emergência dos adultos na primavera-verão 2000/01 (item 5.3.1), cuja alteração foi atribuída à longa estiagem verificada na região e ao conseqüente déficit hídrico no solo. A umidade do solo tem grande importância para a sobrevivência dos insetos (Silveira Neto et al., 1976), pois a baixa umidade pode promover sua dessecação e morte e/ou indiretamente, tornar sua movimentação mais difícil, além da redução do crescimento de raízes e da oferta de alimentos no solo para sobrevivência dos insetos.

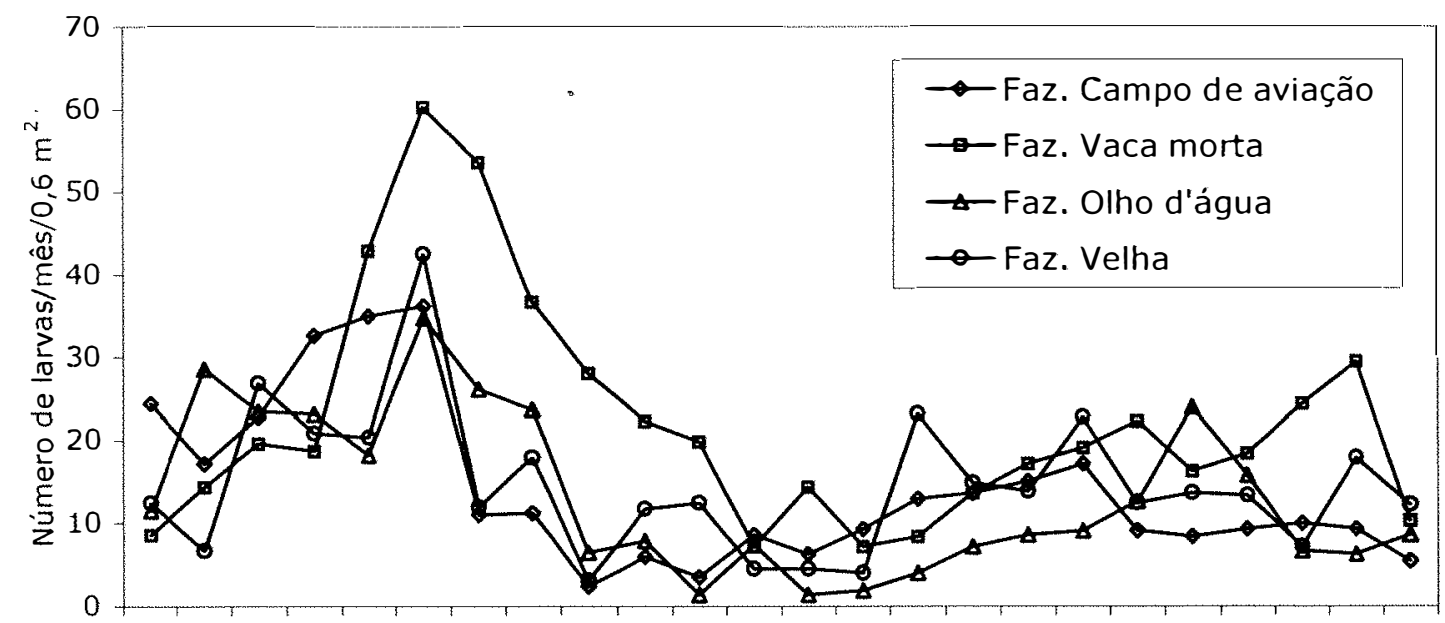

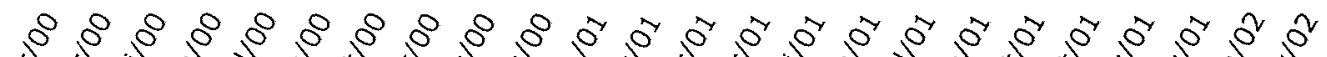
हैं हैं

Figura 8 - Flutuação populacional de larvas dos curculionídeos-das-raizes coletados em citros, em quatro fazendas no município de Itapetininga, SP, de 03/ 2000 a 02/2002. 
Os picos populacionais de pupas precederam os picos de emergência dos adultos (Figura 2 e 9), como esperado, de forma semelhante nos dois anos, nas diferentes áreas; entretanto, emergiu um número relativamente pequeno de adultos em relação ao número de pupas observadas, comprovando haver mortalidade elevada nessa fase; é evidente que durante o longo período larval dos curculionídeos-das-raízes, quando os mesmos ficam expostos aos agentes bióticos e abióticos de mortalidade, a sobrevivência seja baixa, como verificado nos experimentos no telado (item 4.3.2). O efeito adverso da estiagem foi acentuado sobre as fases imaturas, refletindo na emergência dos Naupactini dos citros.

Pelos resultados da pesquisa, e pela experiência adquirida ao longo do estudo, pode-se concluir que a fase adulta dos curculionídeos-das-raizes dos citros é a mais adequada para amostragem da praga, vindo em segundo lugar a amostragem de larvas, embora com mão-de-obra maior.

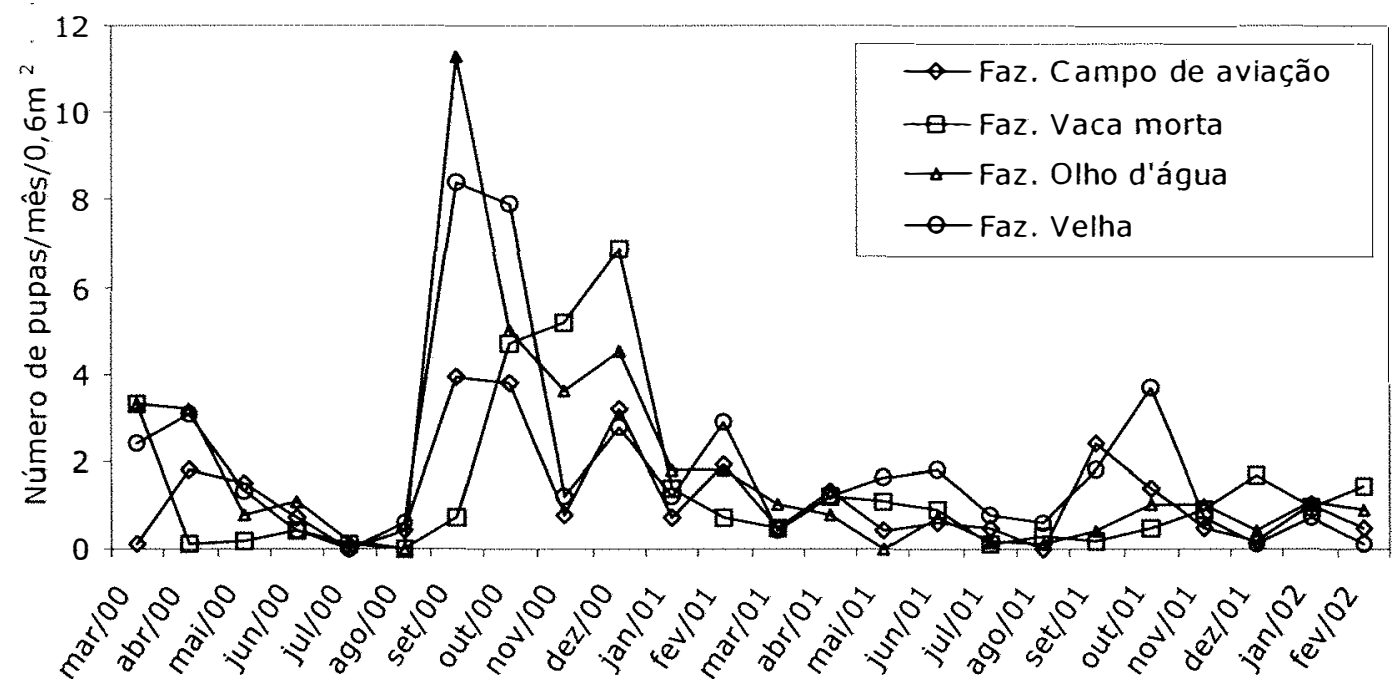

Figura 9 - Flutuação populacional de pupas dos curculionídeos-das-raízes coletados em citros, em quatro fazendas no município de Itapetininga, SP, de 03/2000 a $02 / 2002$. 


\subsection{Conclusões}

- Os curculionídeos-das-raízes são univoltinos, com base na sua flutuação populacional e para cada fase do ciclo biológico, os picos são verificados em períodos determinados, permitindo prever a sua ocorrência para controle;

- A maior parte da população de adultos dos curculionídeos-das-raízes emerge, ou está presente nas laranjeiras, entre outubro e abril, com picos populacionais no início do período, quando é mais fácil sua detecção e quando devem ser adotadas as medidas de controle;

- A maior parte da população de adultos dos curculionídeos-das-raízes emerge, ou está presente nas laranjeiras entre outubro e abril, com picos populacionais no início do período, quando é mais fácil sua deteç̧ão e quando devem ser adotadas as práticas de controle do grupo;

- Naupactus cervinus Boheman e Naupactus versatilis Hustache são encontrados com maior freqüência em Itapetininga, SP, com picos populacionais em épocas diferentes;

- Em campo, as posturas dos curculionídeos-das-raízes são encontradas nos frutos, em maior quantidade no interior e nos terços médio e inferior da copa; *

- As larvas dos curculionídeos-das-raízes ocorrem praticamente o ano inteiro com picos populacionais no período de junho a janeiro;

- Ocorrem pupas na maior parte do ano, com picos populacionais entre outubro e dezembro;

- A estiagem e o conseqüente déficit hídrico no solo, reduzem a população de ovos, larvas, pupas e adultos dos curculionídeos-das-raízes dos citros e distribuem os picos populacionais do ciclo seguinte;

- A fase adulta é a mais adequada para amostragem dos curculionídeos-dasraízes, seguida da fase de larva. 


\section{CONCLUSÕES}

- São registradas quatorze espécies de Naupactini em citros nos estados de São Paulo e Minas Gerais. Onze pertencem ao gênero Naupactus Dejean, uma ao gênero Teratopactus Heller, uma ao gênero Parapantomorus Emden e uma ao gênero Symmathetes;

- Os curculionídeos-das-raízes são encontrados em todas as regiões citrícolas dos estados de São Paulo e Minas Gerais, com maior diversidade na região centro-sul do estado de São Paulo e Naupactus tarsalis Boheman, Parapantomorus fluctuosus (Boheman) e Naupactus versatilis Hustache ocorrem em maior número dos municípios estudados;

- Naupactus cervinus Hustache e $N$. versatilis são encontrados com maior freqüência em Itapetininga, SP e seus picos populacionais ocorrem em épocas diferentes;

- As condições climáticas da região centro-sul do estado de São Paulo, com temperaturas mais amenas e chuvas mais bem distribuidas, podem favorecer a ocorrência e a diversidade dos curculionídeos-das-raízes dos citros;

- As espécies de curculionídeos-das-raízes dos citros apresentam diferenças nas características biológicas, no comportamento de oviposição e no potencial de danificar os citros;

- A postura dos curculionídeos-das-raízes dos citros é realizada em fendas estreitas, sob o cálice do fruto, independente da sua cor, e também em resíduos vegetais e no solo; em campo, as posturas são encontradas nos frutos, em maior quantidade no interior e nos terços médio e inferior da copa; 
- O porta-enxerto influencia a duração do período larva-pupa de $\boldsymbol{N}$. cervinus, que é mais longo em Citrumelo Swingle;

- N. versatilis é potencialmente mais prejudicial aos citros, pois coloca maior número de ovos, apresenta maior longevidade e consome maior área foliar do que $N$. cervinus;

- Os curculionídeos-das-raízes apresentam cinco ínstares larvais e são univoltinos com base na biologia e na flutuação populacional de cada fase do ciclo biológico;

- A maior parte da população de adultos dos curculionídeos-das-raízes emerge, ou está presente nas laranjeiras, entre outubro e abril, com picos populacionais no início do período, quando é mais fácil sua deteç̧ão e quando devem ser adotadas as medidas de controle;

- As larvas dos curculionídeos-das-raízes ocorrem praticamente o ano inteiro com picos populacionais no período de junho a janeiro e as pupas na maior parte do ano, com picos populacionais entre outubro e dezembro;

- A fase adulta é a mais adequada para amostragem dos curculionídeos-dasraízes, seguida da fase de larva;

- A estiagem e o conseqüente déficit hídrico no solo, reduzem a população de ovos, larvas, pupas e adultos dos curculionideos-das-raizes dos citros e distribuem os picos populacionais do ciclo seguinte. 


\section{REFERÊNCIAS BIBLIOGRÁFICAS}

ADAIR, R.C.; NIGG, H.N.; SIMPSON. S.E. et al. Observation of the oviposition process of Diaprepes abbreviatus (Coleoptera: Curculionidae). Florida Entomologist, v.82, n.2, p.362-364, 1999.

ALZUGARAY, R.; RIBEIRO, A.; ZERBINO, R. et al. Situación de los insectos del suelo en Uruguai. In: AVANCES EN EL ESTUDIO DE LA DIVERSIDAD, IMPORTANCIA E MANEJO DE LOS COLEÓPTEROS EDAFÍCOLAS AMERICANOS, 5., Puebla, 1998. Memorias. Puebla: SME;BUAP, 1998. p.151-164.

BEAVERS, J.B. Biology of Diaprepes abbreviatus (Coleoptera: Curculionidae) reared on an artificial diet. Florida Entomologist, v.65, n.2, p.263-269, 1982.

BEAVERS, J.B.; SELHIME, A.G. Flight behavior and dispersal of Diaprepes abbreviatus. Florida Entomologist, v.61, n.2, p.89-91, 1978.

BREWER, M.; VARAS, L. Sistematica y curvas poblacionales de adultos de Pantomorus cinerosus Boheman y Pantomorus taeniatulus Berg, Coleoptera, Curculionidae. Revista da Faculdad de Ciencias Exatas, Físicas e Naturales, v.1, p.17-33, 1974.

COATS, S.A.; McCOY, C.W. Fuller rose beetle (Coleoptera: Curculionidae) ovipositional preference on Florida citrus. Journal of Economic Entomology, v.83, n.3, p.860-865, 1990.

DE JAGER, J.; LATEGAN, K.; VAN DER WESTHUIZEN, M.C. Some aspects of the biology of the white-fringed beetle, Graphognathus leucoloma (Coleoptera: Curculionidae), in the lower Orange River irrigation area of South Africa. Phytophylactica, v.21, p.259-263, 1989. 
HADDAD, M.L.; PARRA, J.R.P.; MORAES, R.C.B. Métodos para estimar os limites térmicos inferior e superior de desenvolvimento dos insetos. Piracicaba: FEALQ, 1999. 29p.

HARDWICK, S.; PRESTIDGE, R.A. Phenology of whitefringed weevil (Graphognathus leucoloma) in pasture in Northern New Zealand. In: PLANT PROTECTION CONFERENCE OF THE NEW ZEALAND, 47., Waitangi, 1994. Proceedings. Palmerston North: NZPPS, 1994. p.257-260.

HARDWICK, S.; PRESTIDGE, R.A. Effects of whitefringed weevil larvae feeding beetle on ryegrass and white clover in the laboratory. In: CONFERENCE OF THE NEW ZEALAND PLANT PROTECTION SOCIETY INCORPORATED, 49., Nelson, 1996. Proceedings. Palmerston North: NZPPS, 1996. p.244-248.

LAKIN, K.R.; MORSE, J.G. A degree-day model for fuller's rose beetle, Pantomorus cervinus (Boheman) (Col., Curculionidae) egg hatch. Journal of Applied Entomology, v.107, p.102-106, 1989.

LANTERI, A.A.; ARAGÓN, J.R. Dinamica poblacional y metodos de control. In: LANTERI, A. A. (Ed.). Bases para el control integrado de los gorgojos de la alfalfa. La Plata: De la Campana Ediciones, 1994. cap.4, p.57-70.

LANTERI, A.A.; NORMARK, B.B. Parthenogenesis in the tribe Naupactini (Coleoptera: Curculionidae). Annals of the Entomological Society of America, v.88, n.6, p.722$731,1995$.

LANTERI, A.A.; DÍAZ, N.B.; MORRONE, J.J. Identificación de las especies. In: LANTERI, A. A. (Ed.). Bases para el control integrado de los gorgojos de la alfalfa. La Plata: De la Campana Ediciones, 1994. cap.1, p.3-40.

LANTERI, A.A.; MARVALDI, A.E. SUÁREZ, S. Gorgojos de la Argentina y sus plantas huéspedes. Tucumán: Sociedad Entomológica Argentina, 2002. Tomo I: Apionidae y Curculionidae, 98p.

LAPOINTE, S.L.; SHAPIRO, J.P. Effect of soil moisture on development of Diaprepes abbreviatus (Coleoptera: Curculionidae) Florida Entomologist, v.82, n.2, p.291-299, 1999. 
LOIÁCONO, M.S.; MARVALDI, A.E. Biologia y daños ocasionados. In: LANTERI, A. A. (Ed.). Bases para el control integrado de los gorgojos de la alfalfa. La Plata: De la Campana Ediciones, 1994. cap.3, p.49-55.

MARVALDI, A.E. Eggs and oviposition habits in Entimini (Coleoptera: Curculionidae). Coleopterists Bulletin, v.53, p.115-126, 1999.

MAULEON, H.; MADEMBA-SY, F. Un ravageur des agrumes aux Antilles françaises: Diaprepes abbreviatus. Fruits, v.43, n.4, p.229-234, 1988.

MAY, B. Immature stages of Curculionidae: larvae of the soil-dwelling weevils of the New Zealand (Insecta: Coleoptera). Journal of Research of Society of New Zealand, v.7, p.189-228, 1977.

McCOY, C.W. Besouros da raiz dos citros: biologia e estratégias atuais de MIP na Flórida. In: DONADIO, L.C.; GRAVENA, S. (Ed.). Manejo integrado de pragas dos citros. Campinas: Fundação Cargill, 1994. cap.1, p.233-254.

MCCOY, C.W.; SEGRETIAN, C.; BEAVERS, G.M. et al. Laboratory rearing and some aspects of the biology of Artipus floridanus (Coleoptera: Curculionidae). Florida Entomologist, v.68, n.3, p.379-385, 1985.

MUNUERA, M.C.M. Diversidade de espécies e controle microbiano de adultos de curculionídeos pragas dos Citrus. Jaboticabal, 1992. 48p. Monografia (Graduação)Faculdade de Ciências Agrárias e Veterinárias, Universidade Estadual Paulista "Júlio de Mesquita Filho".

MURRAY, P.J.; CLEMENTS, R.O. A technique for assessing damage to roots of white clover by root feeding insects. Annals of Applied Biology, v.121, p.715-719, 1992.

OTTENS, R.J.; TODD, J.W. Effects of host plant on fecundity, longevity, and oviposition rate of a whitefringed beetle. Annals of the Entomological Society of America, v.72, n.6, p.837-839, 1979.

PARRA, J.R.P.; HADDAD, M.L. Determinação do número de ínstares em insetos. Piracicaba: FEALQ, 1989. 49p. 
